\title{
Growth factors and management technique used in relation to the developmental rhythm and yield formation pattern of a clover-grass stand
}

SePpo Pulli

University of Helsinki, Department of Plant Husbandry, 00710 Helsinki 71

\begin{abstract}
The effect of the first cutting date and cutting frequency on the clovergrass stand growth and development and on the relationships between plant species were studied at the University of Helsinki in 1974-76. The second study objective was the relationships between several growth factors and the yield components of the stand. The third study area comprised the energy value changes and the photosynthetic activity of the stand during different phases of the growing season.

The most rapid growth and development occurred within the temperature range of $400-500^{\circ} \mathrm{C}\left(\Sigma>0^{\circ} \mathrm{C}\right)$. The late first cutting date increased yields most in the 2and 3-cutting systems and least in the 4-cutting system, due to two summer cuts during the dry period of the season.

Due to the regrowth ability of the species and lack of water in midsummer leading easily to dormancy there was a negative correlation between the first and the second cut and a positive correlation between the following successive cuts.

The most important variables in the regression model describing DM production in the first, second, third and fourth cut were temperature sum in degree days, precipitation during the week before the previous cut, amount of precipitation between cuts and the physiological activity of the stand, respectively.

The energy value of spring and autumn DM yield was higher than that of midsummer. The average photosynthetic efficiency was $0.95 \%$ in 1974 and $0.47 \%$ in 1975 .

The DM content of the yield in spring decreased until the temperature sum of $420^{\circ} \mathrm{C}$ $\left(\Sigma>0^{\circ} \mathrm{C}\right)$ and then increased linearly.

The DM content, protein content, digestibility of DM and protein yield in the total yields were mostly influenced by the first cut if made when the slope showed either decreasing or increasing values of DM content. Otherwise a late first cutting date or low cutting frequency lowered the quality of the forage.

In the mixture the spring growth of timothy ceased by the end of June and was replaced by red-clover. The regrowth of timothy ceased by the middle of July and was replaced by meadow fescue. The growth of red clover was the most uniform throughout the entire growing season.
\end{abstract}

\section{Introduction}

The major part of forage stands in Finland have been clover-timothy mixtures. From 1947 to 1950 the proportion of red clover in forage stands averaged $24 \%$. In 1951, when a comprehensive national study on forage species was conducted, the breakdown was as follows: $27 \%$ clover, $49 \%$ 
timothy, $4 \%$ other forage grasses and $20 \%$ native grasses (PAATELA 1953). According to an investigation in 1966-67, a decrease in the amount of red clover present in forage stands and an increase in that of cultivated grasses had occurred, as the following figures show: $9 \%$ clover, $65-66 \%$ cultivated grasses and 25-26\% other plants (Mukula et al. 1967, MartTila and RaAtiKAINEN 1967). As the previous investigation illustrates, the clover content of forage had changed considerably. Clover has been most abundant in Southern Finland and the least in Lapland (PaAtela 1953, Mukula et al. 1967). Red clover is the most valuable legume for cultivation in Finland (RAvantTi 1955), under which conditions it is a $2-3$ year plant (Linkola 1948, PaAtela 1953). However, the cultivation of red clover disturbs its low winter hardiness. Because of this weakness not many pure clover stands have been established in Finland. Instead, clover-grass mixtures have been used. The grass component has usually been timothy and also meadow fescue or orchard grass if the material is for grazing or silage. Investigations show (RAININko 1968) that, on the average, a clover-grass stand provides dry matter yields higher than those of clover or grasses grown alone and equally as much or more protein than red clover and grass stands respectively. Nevertheless, a shift toward silage stands and an increase in the use of nitrogen have changed the whole growth pattern of grasses and legumes in mixed stands. The cultivated grasses have benefited from the high degree of intensity at the expense of clover. In the silage stands the productivity of different plant species in mixtures has changed from what it would have been when cut for dry hay. In addition, a high cultivation intensity affects different species in different ways when considering their winter hardiness and productivity.

The main objective of this investigation has been to determine, at a relatively high level of intensity $\left(270 \mathrm{~kg} \mathrm{~N} \mathrm{ha}^{-1}\right)$ the influence of the first cutting date and the cutting frequency on the quality and quantity of a clover-grass stand yield as well as on the relationships between the different plant species.

The second objective was to determine the relationships between some growth factors and yield components of the stand at different stages of plant growth during the growing season. The third study area comprised the energy value changes and the photosynthetic efficiency of the stands during different phases of the growing season.

\section{Materials and methods}

\section{Field arrangements}

The investigation was conducted at the University of Helsinki, Department of Plant Husbandry in 1974-76. The study objectives were the influence of the first cutting date and the cutting frequency on the growth and development of a clover-grass stand. The plots were organized as follows:

Experimental design: Split plot

Main plot: Cutting frequency

1. 2-cut

2. 3-cut

3. 4-cut 
Sub-plot:

First cutting date

1. Early (E)

2. Midearly (M)

3. Late (L)

Replications:

Three

The clover-grass stand was established with barley as a companion crop in 1973. The soil type was a sandy silt. The species used were Viikki red clover, Tammisto timothy and Tammisto meadow fescue. A seeding rate of $30 \mathrm{~kg} \mathrm{ha}^{-1}$ comprised the following proportions:

$$
\begin{aligned}
20 \% \text { red clover } & =6 \mathrm{~kg} \mathrm{ha}^{-1} \\
20 \% \text { timothy } & =6 \mathrm{~kg} \mathrm{ha}^{-1} \\
60 \% \text { meadow fescue } & =\frac{18 \mathrm{~kg} \mathrm{ha}^{-1}}{30 \mathrm{~kg} \mathrm{ha}^{-1}} \\
\text { Total } & =30
\end{aligned}
$$

\begin{tabular}{|c|c|c|c|c|c|c|c|c|c|}
\hline \multirow[t]{5}{*}{ 4-cut } & \multicolumn{3}{|l|}{ Spring } & \multicolumn{2}{|c|}{$600 \mathrm{~kg} \mathrm{ha}^{-1}$} & $(15-20-15)=$ & \multicolumn{2}{|c|}{$90 \mathrm{~kg}$} & $\mathrm{~N} \mathrm{ha}^{-1}$ \\
\hline & After & 1st & cut & 240 & , & $(25-0-0)=$ & 60 & - & , \\
\hline & , & 2nd & , & 240 & , & $=$ & 60 & , & , \\
\hline & , & 3rd & , & 240 & , & $=$ & 60 & , & , \\
\hline & & & & & & otal & 70 & kg & ha \\
\hline
\end{tabular}

\section{Fertilization}

\begin{tabular}{|c|c|c|c|c|c|c|c|c|c|c|}
\hline \multirow[t]{4}{*}{ 3-cut } & \multicolumn{3}{|l|}{ Spring } & \multicolumn{2}{|c|}{$600 \mathrm{~kg} \mathrm{ha}^{-1}$} & \multicolumn{2}{|c|}{$(15-20-15)=$} & \multicolumn{2}{|c|}{$90 \mathrm{~kg}$} & $\mathrm{~N} \mathrm{ha}^{-1}$ \\
\hline & After & 1st & cut & 360 & , & $(25-0-0)$ & $=$ & 90 & , & - \\
\hline & , & $2 n d$ & , & 360 & , & , & $=$ & 90 & , & - \\
\hline & & & & & & otal & $=$ & 270 & kg & $\mathrm{ha}^{-1}$ \\
\hline
\end{tabular}

In 1973 the basic fertilization was NPK $600 \mathrm{~kg} \mathrm{ha}^{-1}(10-20-20)$. During the study years 1974-75 the fertilization was as follows:

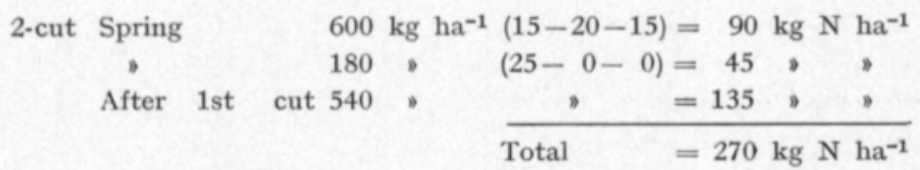

Primary growth $600 \mathrm{~kg} \mathrm{ha}^{-1}(15-20-15)=90 \mathrm{~kg} \mathrm{~N} \mathrm{ha}^{-1}$

For the post effect investigation the stands received $600 \mathrm{~kg} \mathrm{ha}^{-1}(15-20-15)$ in spring and $360 \mathrm{~kg} \mathrm{ha}^{-1}(25-0-0)$ after the first cut in 1976.

\section{Cutting arrangements}

The cutting systems used during 1974-76 are outlined in the schedule below. There was also a primary growth system included, the date given being that of the only cut. In order to test the post effect of the 1974 treatment the orginal plots $\left(15 \mathrm{~m}^{2}\right)$ were divided in half in 1975 , and one half received the 1974 treatments again while the second half was cut three times. In 1976 all plots were harvested twice to test for any post effects. 
Cutting date

\section{Cut 1}

Cut 2

1974

4-cut

$\begin{array}{lrrrr}\text { Early } \ldots \ldots \ldots \ldots \ldots \ldots & 3 / 6 & 8 / 7 & 12 / 8 & 23 / 9 \\ \text { Midearly } \ldots \ldots \ldots \ldots \ldots & 7 / 6 & 12 / 7 & 16 / 8 & 27 / 9 \\ \text { Late } \ldots \ldots \ldots \ldots \ldots \ldots . & 12 / 6 & 16 / 7 & 19 / 8 & 30 / 9\end{array}$

3-cut

$\begin{array}{lllr}\text { Early } \ldots \ldots \ldots \ldots \ldots \ldots & 17 / 6 & 22 / 7 & 30 / 8 \\ \text { Midearly } \ldots \ldots \ldots \ldots \ldots . & 20 / 6 & 26 / 7 & 6 / 9 \\ \text { Late } \ldots \ldots \ldots \ldots \ldots \ldots \ldots & 26 / 6 & 30 / 7 & 12 / 9\end{array}$

2-cut

Early $\ldots \ldots \ldots \ldots \ldots \ldots . . . \ldots \ldots$

Midearly ............ $5 / 7 \quad 26 / 8$

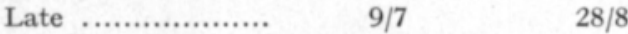

1-cut

$12 / 9$
Cut 3

Cut 4

Cutting date

\begin{tabular}{|c|c|c|c|c|}
\hline & Cut 1 & Cut 2 & Cut 3 & Cut 4 \\
\hline & & 1975 & & \\
\hline \multicolumn{5}{|l|}{ 4-cut } \\
\hline Early & $29 / 5$ & $11 / 7$ & $22 / 8$ & $10 / 10$ \\
\hline Midearly $\quad . . \ldots \ldots \ldots \ldots$ & $3 / 6$ & $16 / 7$ & $27 / 8$ & $10 / 10$ \\
\hline Late $\ldots \ldots \ldots \ldots \ldots \ldots$ & $9 / 6$ & $21 / 7$ & $1 / 9$ & $10 / 10$ \\
\hline
\end{tabular}

3-cut

$\begin{array}{lrrr}\text { Early } \ldots \ldots \ldots \ldots \ldots \ldots & 13 / 6 & 30 / 7 & 10 / 10 \\ \text { Midearly } \ldots \ldots \ldots \ldots \ldots & 18 / 6 & 4 / 8 & 10 / 10 \\ \text { Late } \ldots \ldots \ldots \ldots \ldots \ldots \ldots & 23 / 6 & 8 / 8 & 10 / 10\end{array}$

2-cut

$\begin{array}{lrr}\text { Early } \ldots \ldots \ldots \ldots \ldots \ldots & 27 / 6 & 10 / 10 \\ \text { Midearly } \ldots \ldots \ldots \ldots \ldots & 2 / 7 & 10 / 10 \\ \text { Late } \ldots \ldots \ldots \ldots \ldots \ldots \ldots & 7 / 7 & 10 / 10\end{array}$

1-cut

$25 / 7$

Post effect

Post effect

$24 / 6$

308

\section{Laboratory studies}

Dry matter content was determined from two $200 \mathrm{~g}$ chopped samples that were dried for $36 \mathrm{~h}$ at $100^{\circ} \mathrm{C}$. Raw protein and digestibility samples were dried for $36 \mathrm{~h}$ at $70^{\circ} \mathrm{C}$.

The raw protein content was determined from a dried and ground sample according to the KJELDAHL technique. Dry matter digestibility was determined with an one-stage chemical procedure for cellulase digestibility as described by Jones and HAYward (1973). Cellulase DM digestibility was changed to DM in vitro digestibility according to the correlation model outlined by Pulli (1976). 
The dry matter energy content was determined from a $10 \mathrm{mg}$ sample with a PHILLIPSON oxygen microbomb calorimeter according to PHILlipson's (1964) procedure.

The botanical analyses were carried out with a $1 \mathrm{~kg}$ sample of the forage by separating the main plant species, couch-grass and the dead material of the yield from each other.

Crop growth and yield analyses.

Stand height was measured for each cut from five points within each plot during 1974-76. Dry matter, raw protein, digestibility samples and samples for the botanical analyses were taken at the time of cutting, put in plastic bags and dealt with as soon as possible. Meteorological data was obtained from the weather station at nearby Malmi airport. The analysis of variance, correlation determinations and regression models were calculated by using the University computer at Viikki.

\section{Weather conditions}

On the whole, the growing season of 1974 was rainier than the long-term average. Spring was cooler than normal (Table 1) and the amount of precipitation for May-June was close to the long-term average. From August to the

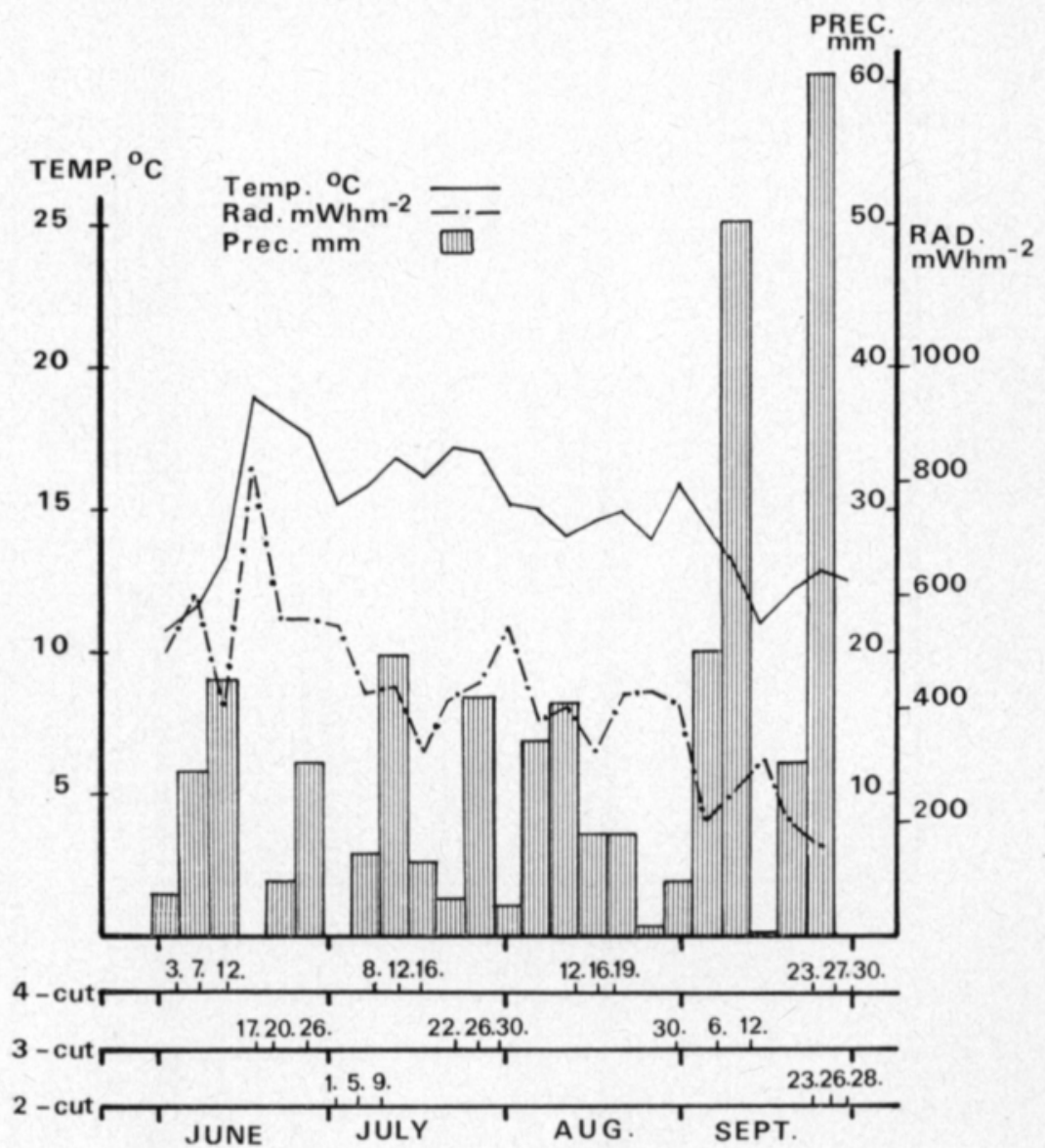

Fig. 1. Weather conditions and cutting dates in different cutting systems in 1974. 
end of the growing season rainfall exceeded the normal level. For example, September's precipitation was more than twice the long-term average.

The growing season of 1975 can be considered as warm and dry (Table 1). In particular, May was very warm, but June was cooler than the long-term average. From July onward temperatures were $1-2^{\circ} \mathrm{C}$ higher than the average. The amount of precipitation during the growing season was less than normal.

Table 1. Average temperature $\left({ }^{\circ} \mathrm{C}\right)$ and precipitation $(\mathrm{mm})$ May-Sept. in $1974-76$ and the long term average $1931-60$ at Malmi airport.

\begin{tabular}{lcccccccc}
\hline Month & \multicolumn{3}{c}{ Temperature ${ }^{\circ} \mathrm{C}$} \\
& 1974 & 1975 & 1976 & $1931-60$ & 1974 & 1975 & 1976 & $1931-60$ \\
\hline \multirow{2}{*}{ May } & 7.0 & 11.7 & 10.7 & 8.4 & 32 & 38 & 27 & 41 \\
June & 14.3 & 13.7 & 13.0 & 14.1 & 46 & 12 & 42 & 47 \\
July & 15.9 & 18.0 & 15.9 & 17.2 & 50 & 26 & 52 & 68 \\
Aug. & 14.3 & 16.6 & 15.2 & 15.6 & 75 & 29 & 45 & 70 \\
Sept. & 12.6 & 13.3 & 8.1 & 10.5 & 126 & 53 & 48 & 66 \\
& 12.8 & 14.7 & 12.6 & 13.2 & 329 & 158 & 214 & 292 \\
\hline
\end{tabular}

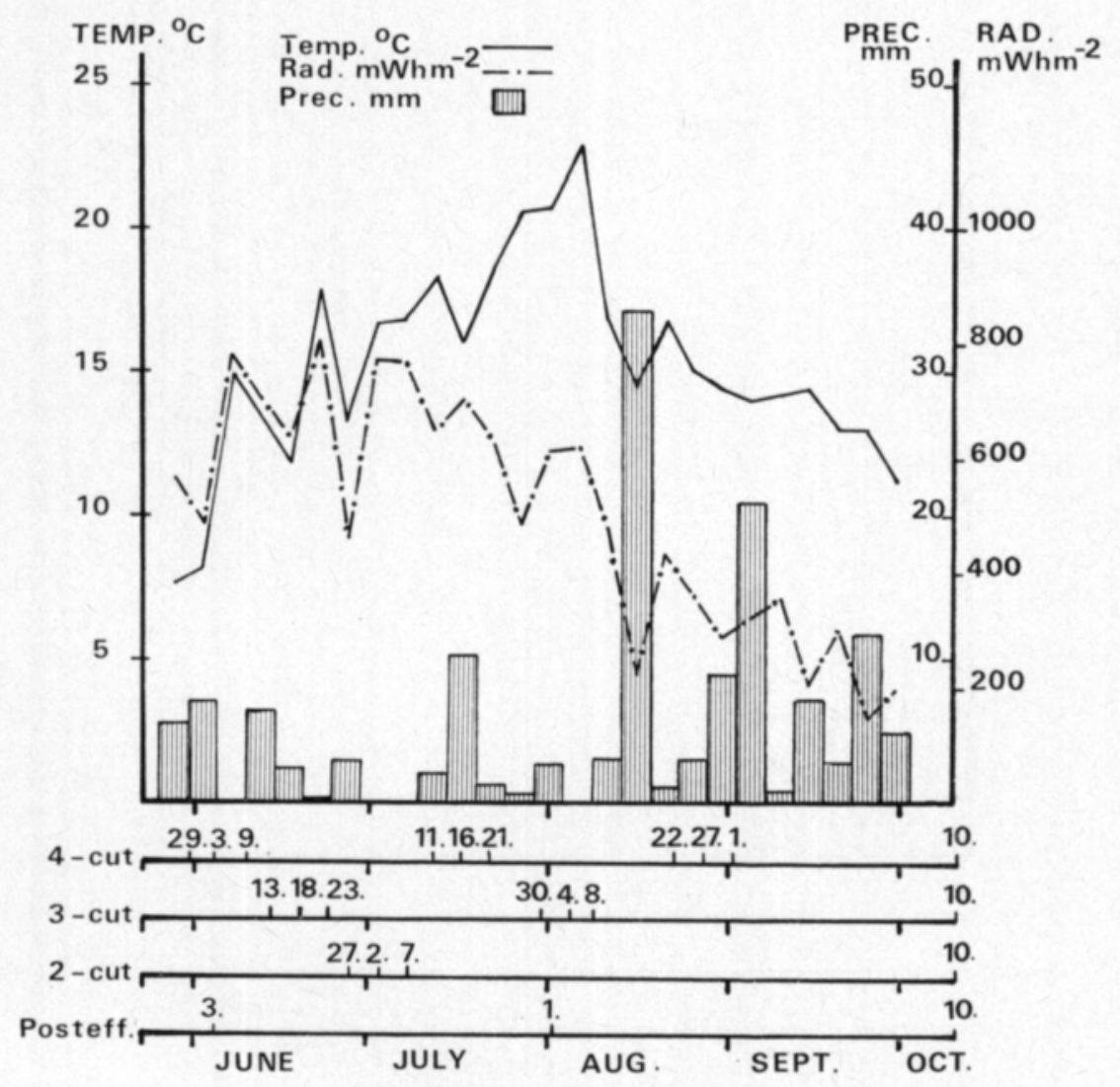

Fig. 2. Weather conditions and cutting dates in different cutting systems in 1975. 


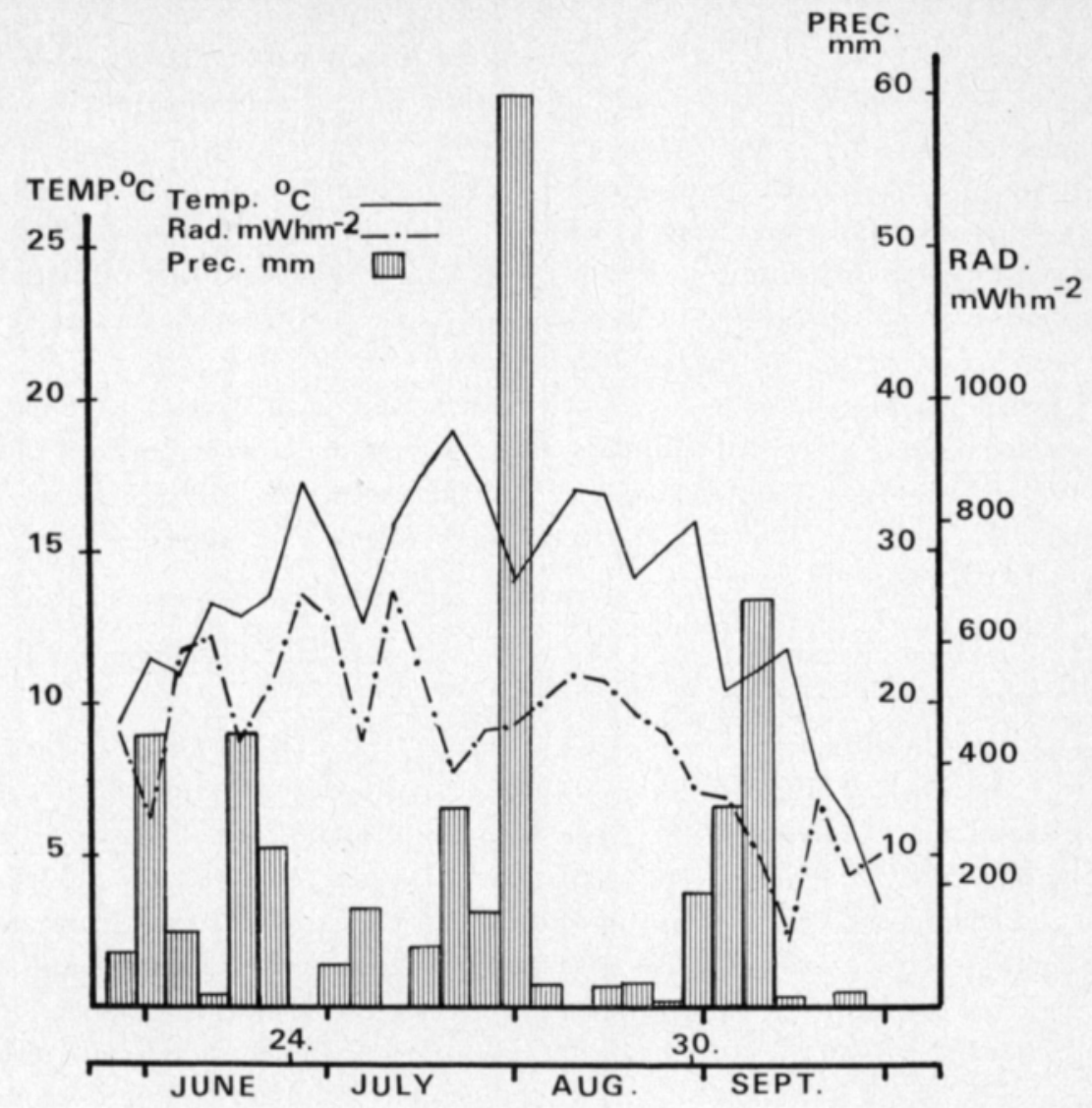

Fig. 3. Weather conditions and cutting dates in post effect cuttings in 1976.

In 1976, the midsummer was cooler than normal as well as drier. The good conditions in May and August could not prevent the 1976 yield from being a less than good one.

In Figures $1-3$ the growing seasons' average temperatures and radiations, amounts of precipitation and cutting times are shown. Attention is drawn to midsummer of 1975 which was marked by early summer dryness.

\section{Results and discussion}

\section{1. Dry matter production}

The dry matter yield of a cultivated forage stand increases as the stand ages (Poijärvi 1931, Huokuna 1960, Pestalozzi and Qyen 1977). The growth follows a sigmoidal growth pattern. Especially in the spring the dry matter yield increases exponentially. This phase is followed by a linear period of growth in which the dry matter increases by about $200 \mathrm{~kg}$ per day (LEAFE et al. 1974). 
RAPPE (1948) investigated a stand's growth in a pasture at a rather young stage of development. He found out that growth slowed down in the autumn inspite of the plants being young and healthy and all growth factors near the optimum. The retarded plant growth in the autumn is due to the action of plant hormones. In the spring a wintered plant is ready to beging immediate production of a stalk, flowers and seeds. After this, vegetative growth slows down as autumn approaches. Dry periods which often occur in midsummer can also slow the growth of pasture plants.

During the period of its strongest growth and with only limited nitrogen fertilizers, pasture grass can produce about $100 \mathrm{~kg} \mathrm{ha}^{-1}$ of dry matter per day. In July it drops to about $50 \mathrm{~kg} \mathrm{ha}^{-1}$, in August to $30-40 \mathrm{~kg} \mathrm{ha}^{-1}$ and then eventually ceases by the end of the autumn (Huokuna 1964).

\subsubsection{Growth factors in relation to the DM yield}

The interdependence between the yield and growth factors has interested many researchers. Finnish research people have been studying this issue since the last century. In the oldest studies Lemström (1878) and Johansson (1912) determined the influence of sun spots on the yield. Johansson (1924) dealt with the correlations between grain and potato yields and temperature, rainfall and cloudiness. KERÄNEN (1925) determined the influence of winter and spring temperature conditions on productivity. KERÄNEN's later studies (1931) familiarized the causal connection between yield level and meteorological factors. The effect of temperature on the yield of grain crops, were studied by Kirskinen (1957) and PaAtela (1958). The effects of weather factors on sugar beet (BRUMMER 1961) and potato yields have been studied by TÄHTINEN (1962), Yllö (1963, 1964), VARIS (1970) and SEPPänen (1971). The relations between crop productivity and weather conditions at different experimental stations have been studied by Salminen (1930), Pohjakallio (1943), Pessi (1958 a, 1958 b), Роhjanheimo (1959), Saloheimo (1956) and Multamäki (1961).

Individual growth factors such as light conditions have been studied by Pohjakallio and Salonen (1947), and Pohjakallio (1951 a, 1951 b, 1952 , $1954,1957)$. The effects of dry periods have been studied by KorHONEN (1920) and those of temperature by Stigell (1920), Sinisalo (1937), PaATEla and Suomela (1960). SoINI (1965) studied the influence of weather conditions on the yield with regard to the fertilization and soil factors. Water economy questions have been dealt with by Hooli (1971).

The risk studies conducted by the Agricultural Research Centre have determined the crop certainty of sugar beets (KALLINEN et al. 1976), rye (Mukula et al. 1976) and winter wheat (Mukula and Rantanen 1976). The Centre has also dealt with the general factors affecting the yield level (MELA and HaApalainen 1976), the growth risks of barley (Mukula et al. 1977) and oats (MUKUla et al. 1978) and the area preconditions for spring cereals (MUKULA and Rantanen 1978). Quality risks have been investigated for fodder barley (VARIS et al. 1979) and oats (VARIS et al. 1979). 
Results:

Cut 1.

During 1974-76 the first cuts of the cutting systems were conducted between 29.5.-9.7. All of the growth factors included correlated significantly with the dry matter production (Table 2). The factor with the strongest relationship was the temperature sum in degree days $\left(\Sigma>0^{\circ} \mathrm{C}\right)$ which was in turn automatically correlated to the growing time. The weakest correlation was to the precipitation during spring growth. This was most likely because of enough soil water.

The highest coefficient of determination for the clover-grass spring growth in the first cut was given by the selective regression equation: where

$$
\mathrm{Y}=-3363.3+20.92 \mathrm{X}_{1}-70260 \mathrm{X}_{2}+307.52 \mathrm{X}_{3} \quad\left(\mathrm{~F}=160.8^{* * *}\right)
$$

$$
\begin{aligned}
& \mathrm{X}_{1}=\text { temperature sum in degree days }\left(\Sigma>0^{\circ} \mathrm{C}\right) \frac{\mathrm{R}^{2}}{91.4} \\
& \mathrm{X}_{2}=\text { total radiation } \operatorname{sum}\left(\Sigma \mathrm{Wh} \mathrm{cm}^{-2}\right) \\
& \mathrm{X}_{3}=\text { growing time }(\Sigma \text { days }) \quad 97.2
\end{aligned}
$$

It was significant that temperature alone accounted for $91.4 \%$ of the yield formation and the total model for $97.2 \%$. This meant only a very small percentage remained outside the regression model.

\section{Cut 2.}

The second cuts of each cutting system fell during the dry period of the summer. This resulted in strong correlations to the amount of precipitation during the week before the first cut (Table 2). The negative correlation between the yield of the first cut and that of the second means that delay of the first cut automatically reduced the yield of the second cut. The second cuts were made between 8.7 and 10.10 , and due to lack of moisture negative correlations occurred between the yield and the growing time, temperature sum and total radiation.

Table 2. The correlation coefficients between growth factors and DM yield in the first, second, third and fourth harvest of clover-grass stand in 1974-76.

\begin{tabular}{llllll}
\hline \multirow{2}{*}{ Growth factors } & \multicolumn{4}{c}{ Cuts } \\
\cline { 3 - 6 } & & 1st & 2nd & 3rd & 4 th \\
\hline & & & & & \\
$\Sigma$ days & (time) $\ldots \ldots \ldots \ldots \ldots \ldots \ldots \ldots \ldots \ldots$ & $.93^{* * *}$ & $-.44^{*}$ & $-.69 * * *$ & $.25 \mathrm{NS}$ \\
$\Sigma>0^{\circ} \mathrm{C}$ & (temp.) $\ldots \ldots \ldots \ldots \ldots \ldots \ldots \ldots \ldots$ & $.96^{* * *}$ & $-.49^{* *}$ & $-.80^{* * *}$ & $.46 \mathrm{NS}$ \\
$\Sigma \mathrm{Wh} \mathrm{cm}{ }^{-2}$ & (rad) $\ldots \ldots \ldots \ldots \ldots \ldots \ldots \ldots \ldots \ldots$ & $.90^{* * *}$ & $-.47^{*}$ & $-.78^{* * *}$ & $.66^{*}$ \\
$\Sigma \mathrm{mm}$ & (prec.) $\ldots \ldots \ldots \ldots \ldots \ldots \ldots \ldots \ldots \ldots$ & $.79^{* * *}$ & .17 & $-.26 \mathrm{NS}$ & $.80^{* *}$ \\
$\Sigma \mathrm{mm}$ & (prec. previous cut) $\ldots \ldots \ldots \ldots$ & & $.83^{* * *}$ & $.88^{* * *}$ & $.33 \mathrm{NS}$ \\
$\mathrm{DM} \mathrm{kg} \mathrm{ha-1}$ & (previous cut) $\ldots \ldots \ldots \ldots \ldots \ldots \ldots$ & & $-.38^{*}$ & $.54^{*}$ & $.91^{* * *}$ \\
\hline
\end{tabular}


The highest coefficient of determination, $85.7 \%$, for the second cut's dry-matter yield was given by the following regression model:

$$
\begin{aligned}
& \mathrm{Y}=850.4+54.25 \mathrm{X}_{1}+252.48 \mathrm{X}_{2}+83.90 \mathrm{X}_{3}-211.24 \mathrm{X}_{4} \quad(\mathrm{~F}=32.94 * * *) \\
& \text { where: }
\end{aligned}
$$

\begin{tabular}{|c|}
\hline $\mathbf{X}_{1}=$ precipitation during a week before previous cut $(\Sigma \mathrm{mm})$ \\
\hline $\mathrm{X}_{i}=$ total radiation sum $\left(\Sigma \mathrm{Wh}^{-2}\right)$ \\
\hline $\mathrm{X}_{3}=$ precipitation between cuts $(\Sigma \mathrm{mm})$ \\
\hline $\mathrm{X}_{4}=$ growing time ( $\Sigma$ days $)$ \\
\hline
\end{tabular}

The precipitation during the week before the first cut accounted for $69 \%$ of the second cuts' dry matter yield. Also the total radiation sum and the precipitation between cuts had positive influences on the yield. Increasing the growing period, on the other hand, is a sign some growth factor is lacking and therefore means negative relations to the yield.

\section{Cut 3.}

The time of the third cuts, $12.8-10.10$, represented the least productive period of the growing season. The dry matter yield had a positive correlation to the precipitation during the week before the second cut (Table 2). The positive correlation to the previous yield meant the presence of a physiologically active state of growth in the stand at the time of the previous cut. Growing time, temperature sum and total radiation sum correlated negatively with the third cut's DM yield.

The coefficient of determination, $86.6 \%$, was provided by the following selective regression equation:

$$
\begin{aligned}
& \begin{array}{ll}
\mathrm{Y}=-2573.1+190.94 \mathrm{X}_{1}+25.65 \mathrm{X}_{2}-0.20 \mathrm{X}_{3} \quad(\mathrm{~F}=36.59 * * *) \\
\text { where: }
\end{array} \\
& \begin{array}{ll}
\mathrm{X}_{1}=\text { precipitation during a week before previous cut }(\Sigma \mathrm{mm}) & \frac{\mathrm{R}^{2}}{77.3} \\
\mathrm{X}_{2}=\text { precipitation between cuts }(\Sigma \mathrm{mm}) & 84.6 \\
\mathrm{X}_{3}=\text { DM yield in previous cut }\left(\mathrm{kg} \mathrm{ha}^{-1}\right) & 86.6
\end{array}
\end{aligned}
$$

The amount of precipitation in the regression model positively influenced the yield level. There was negative effect in the regression model concerning the DM yield of the previous cut probably due to the water factors.

\section{Cut 4 .}

The fourth cut of the summer included the 4-cut system's final cuts which during the study years $1974-75$ occurred in the period of $23.9 .-10.10$. The DM yield of the fourth cut correlated strongly with the DM yield in the third cut. This means that if the stand is dormant at the time of the third cut which follows the driest and hottest period of the summer, regrowth does not occur. The yield of the fourth cut is increased by the autumn rains, but inhibited by the decrease in light assosiated with autumn. Grasses also grow satisfactcrily at rather low temperatures, meaning that some other growth factors are more important than temperature to the development of the fourth cut's yield. 
The following regression model best described the autumn yield: where:

$\mathrm{Y}=-782.2+0.64 \mathrm{X}_{1}+32.51 \mathrm{X}_{2}\left(\mathrm{~F}=25.26^{* *}\right)$

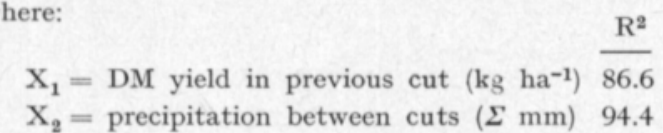

The stand's physiologic activity at the time of the third cut accounted for $86.6 \%$ of the variation. The complete model accounted for $94.4 \%$.

\section{1. 2. Dry matter yields and first cutting dates}

VALle and Virtanen (1932) showed that the earlier the growth stage of the stand at which the first cut is made the better regrowth ability the stand has. However, the weather conditions of the growing season may influence the amount of regrowth. In PoIJÄrvI's (1931) studies the productivity of timothy was compared at three stages of development, at heading and at the beginning and at the end of timothy flowering. The total yields consisted of the aftermath harvested at the same time from all treatments. The greatest amounts of feed units and digestible raw protein were obtained from the stand harvested at the beginning of timothy's flowering. Delaying the harvest increased the yield but decreased the quality even more. TeitTinen (1959) studied the first cutting dates of a clover-grass stand. When the harvest was changed from the time of timothy heading to where the clover had already flowered, the yield was doubled. The abundant regrowth following an early cut could not compensate for the yield increase in the late cut. The ranking of cutting dates according to productivity was the late 2-cut, early 2-cut, 3-cut and the 1-cut. Jäntti and Heinonen (1957) and RaIninko (1968) showed that the highest dry matter yield could be obtained from a stand cut twice, but if the conditions for regrowth were very good, then the highest yield and the best quality could be obtained through four cuts.

According to the results of OLder and Linnutaja (1976) in Estonia the number of harvest influences in different ways a plant in different stages of development. With $100 \mathrm{~kg} \mathrm{~N} \mathrm{ha}^{-1}$ orchard grass and meadow fescue produced the highest dry matter yields when cut two times during flowering. The following order of productivity was three cuts during heading and four cuts during stem development. Timothy, on the other hand, gave the highest yield when cut three times during heading. The productivity following this stage was three cuts during stem development, two cuts during flowering and five cuts during the shooting period. When treated with $300 \mathrm{~kg} \mathrm{~N} \mathrm{ha}^{-1}$ the productivity favored four cuts for orchard grass and meadow fescue, but only two cuts for timothy. The lowest yield was obtained from stands at an early stage of plant development.

\section{Results}

The dates of the first cuts and the yields for each cut in the three cutting systems are presented in Fig. 4. The yield of each cut as a percentage of the total yields (Table 3 ) shows that 1974 was a normal, productive year for growth 

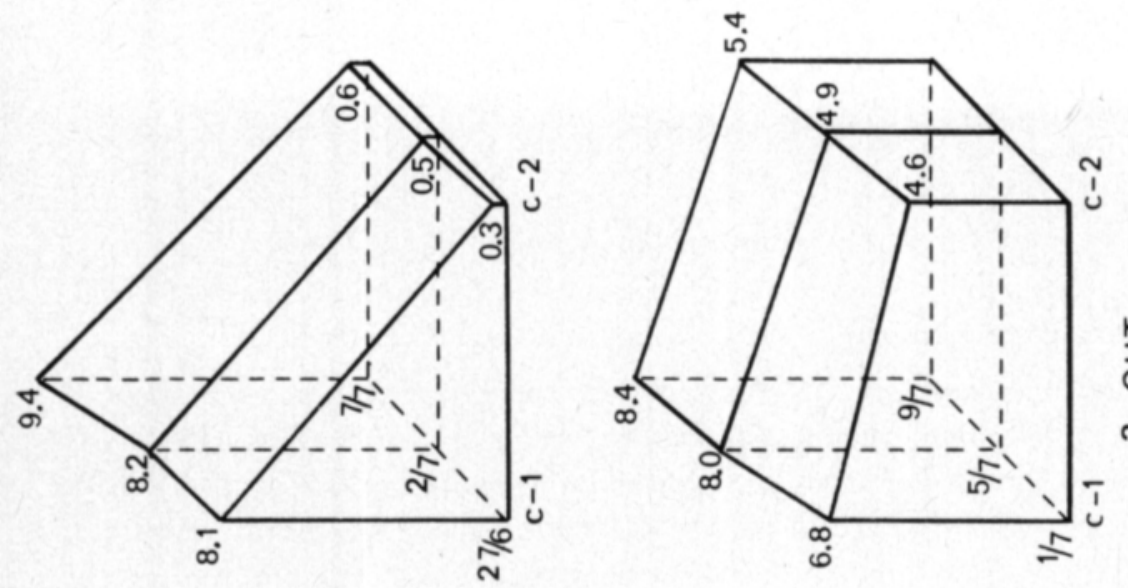


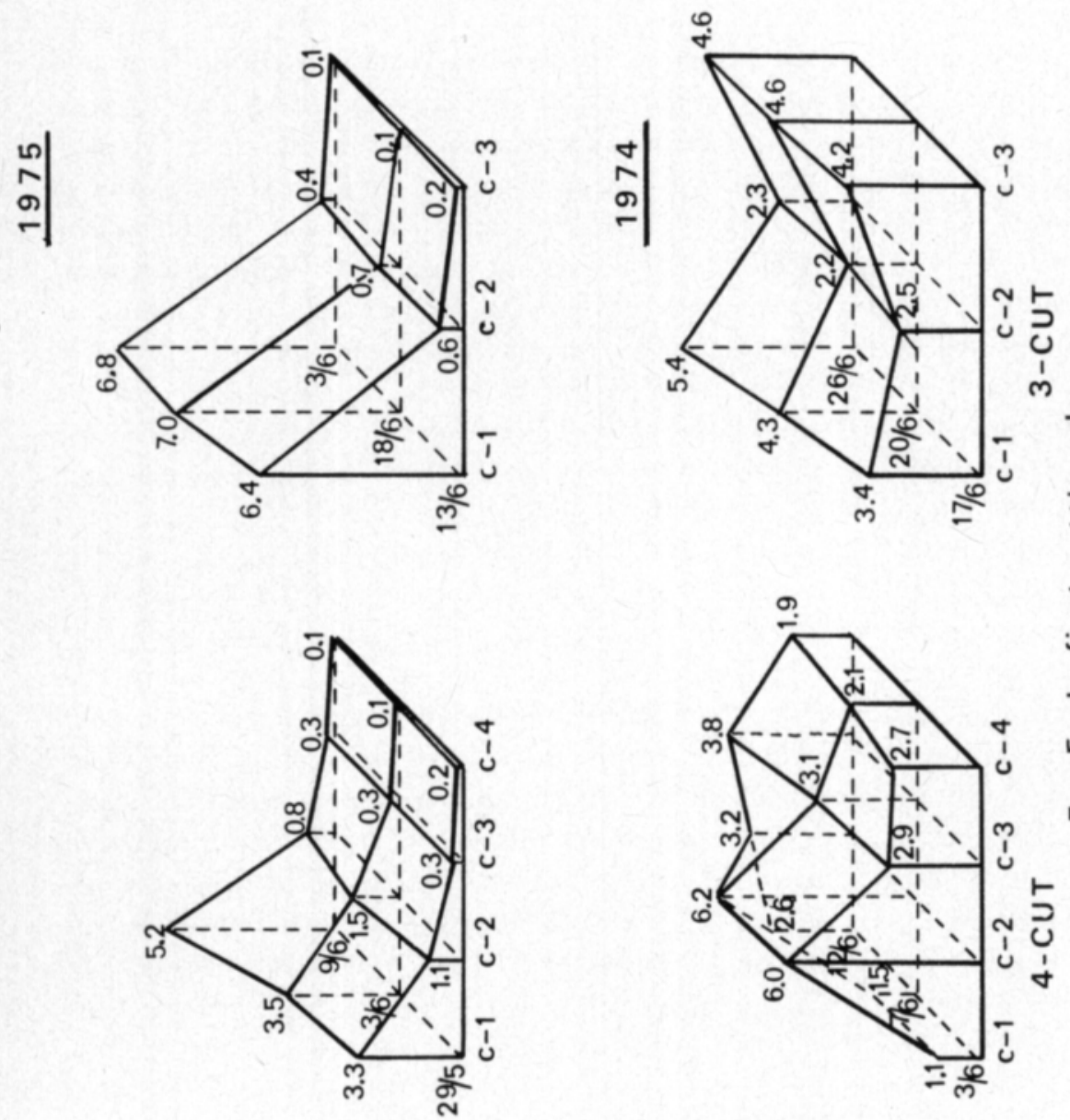

茫文

$\geq \stackrel{0}{0} 0$

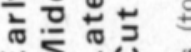

" I"

$\Sigma \Sigma \sim u$ 
whereas 1975 had good growing conditions only in the spring. The highest yield in the 4-cut system in 1974 was obtained at the early and midearly cuts of the second cut. At the late cutting date the yield distribution per cut was more balanced and the highest yield level was in the third cut. When the first cut of the 3-cut system was late, the regrowth ability of the stand was lost in the second and third cuts (Table 3). In the 2-cut system delay of the first cut did not especially affect the distribution of the yield in either cut. In 1975 a very wet May contributed noticeably to stand development. This was followed by four weeks of dryness. Because of the dry conditions only the spring growth was of any significance to the 1975 yield.

Table 3. Yield distribution of clover-grass stand measured in $\%$ cut per total yield with three first cutting dates in 4-cut, 3-cut and 2-cut systems.

\begin{tabular}{|c|c|c|c|c|c|c|c|c|}
\hline \multirow{2}{*}{ Cuttings } & \multicolumn{8}{|c|}{ First cutting date } \\
\hline & \multicolumn{4}{|c|}{1974} & \multicolumn{4}{|c|}{1975} \\
\hline 4-cut & $3 / 6$ & $7 / 6$ & $12 / 6$ & Avg. & $29 / 5$ & $3 / 6$ & $9 / 6$ & Avg. \\
\hline Cut 1 & 9 & 12 & 23 & 14 & 68 & 65 & 82 & 72 \\
\hline Cut 2 & 47 & 48 & 28 & 41 & 22 & 28 & 11 & 20 \\
\hline Cut 3 & 23 & 24 & 33 & 27 & 6 & 5 & 5 & 5 \\
\hline Cut 4 & 21 & 16 & 16 & 18 & 4 & 2 & 2 & 3 \\
\hline 3-cut & $17 / 6$ & $20 / 6$ & $26 / 6$ & Avg. & $13 / 6$ & $18 / 6$ & $23 / 6$ & Avg. \\
\hline Cut 1 & 34 & 39 & 44 & 39 & 89 & 91 & 94 & 91 \\
\hline Cut 2 & 25 & 20 & 19 & 21 & 8 & 8 & 5 & 7 \\
\hline Cut 3 & 41 & 41 & 37 & 40 & 3 & 1 & 1 & 2 \\
\hline 2-cut & $1 / 7$ & $5 / 7$ & $9 / 7$ & Avg. & $27 / 6$ & $2 / 7$ & $7 / 7$ & Avg. \\
\hline Cut 1 & 59 & 62 & 60 & 60 & 95 & 94 & 94 & 94 \\
\hline Cut 2 & 41 & 38 & 40 & 40 & 5 & 6 & 6 & 6 \\
\hline
\end{tabular}

In 1974 the best regrowth in the 4-cut system occurred after the first cut. The main principle was that the delay of the first cut reduced the regrowth ability in the second cut (Table 4). The regrowth ability in the second cut was decreased when the first cutting date was delayed, with one exception, the late first cutting date in the 3-cut system (Fig. 4, Table 4). In 1975 severe dormancy in midsummer changed the whole pattern of growth and development (Fig. 4, Table 4).

The formation of total yields (Table 5) shows that the delay of the first cut in the spring increased the total yields most in the 2-cut system and least in the 4-cut system. The same trend can be seen also in the average yields of the study years as well as in the total yields of the research years (Table 5). 
Table 4. Regrowth ability of clover-grass stand \% DM of a cut compared to a previous cut measured at three levels of first cutting dates in three different cutting systems.

\begin{tabular}{|c|c|c|c|c|c|c|}
\hline \multirow{2}{*}{ Cuttings } & \multicolumn{6}{|c|}{ First cutting date } \\
\hline & & 1974 & & & 1975 & \\
\hline 4-cut & $3 / 6$ & $7 / 6$ & $12 / 6$ & $29 / 5$ & $3 / 6$ & $9 / 6$ \\
\hline Cut 1 & 100 & 100 & 100 & 100 & 100 & 100 \\
\hline Cut 2 & 564 & 428 & 122 & 33 & 42 & 14 \\
\hline Cut 3 & 48 & 49 & 117 & 27 & 21 & 37 \\
\hline Cut 4 & 91 & 65 & 50 & 69 & 39 & 38 \\
\hline 3-cut & $17 / 6$ & $20 / 6$ & $26 / 6$ & $13 / 6$ & $18 / 6$ & $23 / 6$ \\
\hline Cut 1 & 100 & 100 & 100 & 100 & 100 & 100 \\
\hline Cut 2 & 73 & 52 & 43 & 9 & 9 & 5 \\
\hline Cut 3 & 167 & 206 & 199 & 34 & 15 & 15 \\
\hline 2-cut & $1 / 7$ & $5 / 7$ & $9 / 7$ & $27 / 6$ & $2 / 7$ & $7 / 7$ \\
\hline Cut 1 & 100 & 100 & 100 & 100 & 100 & 100 \\
\hline Cut 2 & 67 & 61 & 64 & 3 & 6 & 4 \\
\hline
\end{tabular}

\subsubsection{Photosynthetic efficiency of clover-grass stand}

Because $90-95 \%$ of the total dry matter yield of higher plants consists of carbon compounds which are products of photosynthesis, light, as the energy source of photosynthesis, is a very important growth factor. Researchers have tried to determine what amount of the radiation reaching the plant surface is transformed through photosynthesis into carbon compounds. The energy value of a clover-grass stands assimilation products are about $0.41-0.80 \%$ of the total radiation (NoDdAcK and Komor 1937). Maximov (1938) found that green plants converted $\mathbf{1 - 5} \%$ of the total radiation into organic energy. According to Rabinowitch (1945) crop yields and forest growth utilize $0.8 \%$ of the total radiation, equal to $2 \%$ of the visible light used for synthesis by plants in the areas which have relatively short growing seasons.

In Holland Wassink (1948) determined the net photosynthetic efficiency in different types of cultiveted plants to be $0.5-2.2 \%$. The photosynthetic efficiency varied throughout the growing season according to the stage of development of the plants. Assimilation was most efficient during the period of the greatest increase in growth. During the most intensive growing period of barley the photosynthetic efficiency was $13.6 \%$.

The age of cell tissue affects the rate of assimilation. The most effective assimilation occurs in alfalfa leaves at the age of 5-17 days. The leaves remain effective only for about one month (Fuess and TESAR 1968). According to Loomis and Williams (1963) the factors mostly limiting the beneficial utilization of radiation are mainly the leaf area index (LAI), leaf location on the plant, leaf orientation, the plant's net photosynthetic capacity and the available amount of $\mathrm{CO}_{2}$.

The density of a stand reduces the amount of light which reaches the inner parts of the stand and this in turn affects photosynthesis. In full daylight the 
Table 5. Average dry matter yields of clover-grass stand with three different first cutting dates harvested two, three and four times per season in 1974-75.

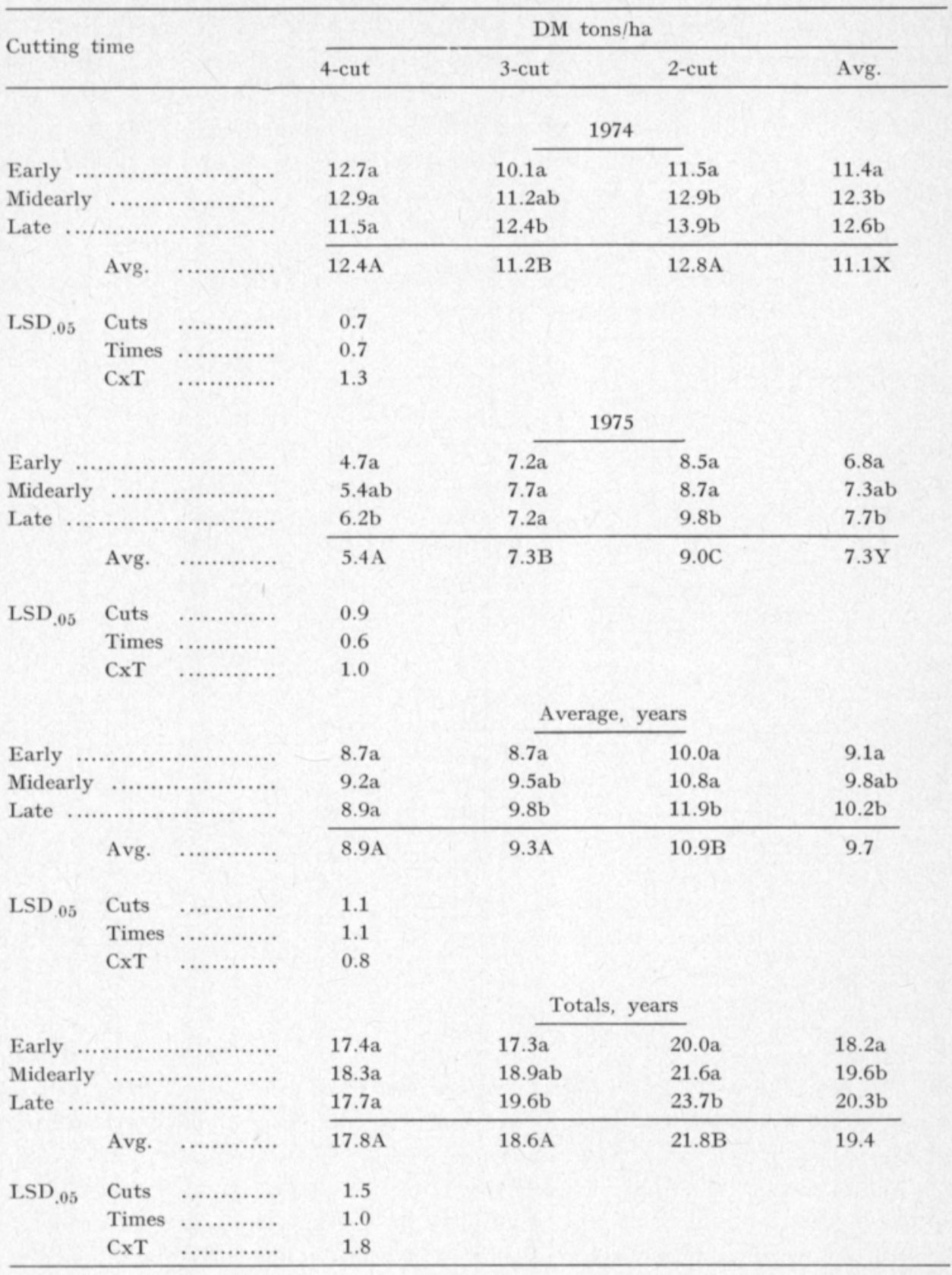

growing seasons net photosynthesis has been $2.9 \%$. When the amount of light was reduced by $25 \%$ the resulting intensity of photosynthesis was $1.4 \%$ (KAMEL 1959). Other effects arising from a limited amount of light were a longer growing period, thinner leaves, lower 1000 seed weight, small root system, long vegetative growth stage and a bigger leaf/shoot ratio. 
PHOTOS.

EFF.

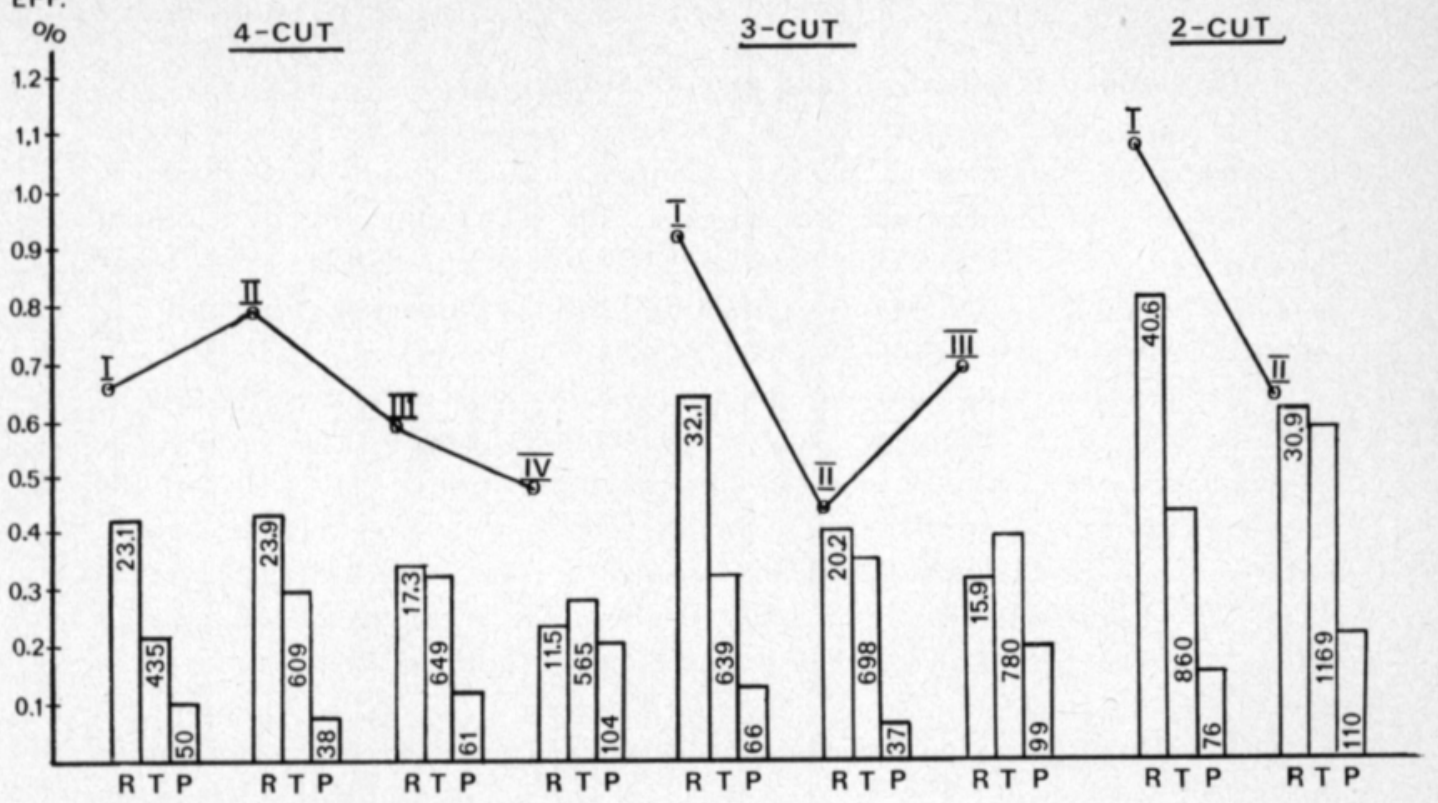

$R=$ Total radiation, $\Sigma W h \mathrm{~cm}^{-2}$, per cut

$T=$ Temperature sum in degreedays, $\Sigma>0^{\circ} \mathrm{C}$, per cut

$\mathbf{P}=$ Preeipitation, $\Sigma \mathrm{mm}$, per cut

Fig. 5. Average photosynthetic efficiency, solar radiation, temperature sum and precipitation in individual cuts of clover-grass stand harvested two, three and four times in 1974-75.

Table 7. Photosynthetic efficiency, $\%$ of total radiation of clover-grass stand with three first-cutting dates, harvested two. three and four times per season in 1974-75.

\begin{tabular}{|c|c|c|c|c|}
\hline \multirow{2}{*}{ Cutting time } & \multicolumn{4}{|c|}{ Photosynthetic efficiency \% } \\
\hline & 4-cut & 3-cut & 2-cut & Avg. \\
\hline & \multicolumn{4}{|c|}{1974} \\
\hline \multirow{3}{*}{$\begin{array}{l}\text { Early } \ldots \ldots \ldots \ldots \ldots \ldots \ldots \ldots \\
\text { Midearly } \\
\text { Late }\end{array}$} & $0.95 \mathrm{a}$ & $0.84 \mathrm{a}$ & $1.01 \mathrm{a}$ & $0.93 \mathrm{a}$ \\
\hline & $0.95 a$ & $0.87 \mathrm{a}$ & 1.08 & $0.96 \mathrm{a}$ \\
\hline & $0.83 a$ & $0.94 \mathrm{a}$ & $1.12 \mathrm{a}$ & $0.96 \mathrm{a}$ \\
\hline Avg. & $0.91 \mathrm{~A}$ & $0.88 \mathrm{~A}$ & $1.07 \mathrm{~A}$ & $0.95 \mathrm{~A}$ \\
\hline & \multicolumn{4}{|c|}{1975} \\
\hline \multirow{3}{*}{$\begin{array}{l}\text { Early } \\
\text { Midearly } \\
\text { Late }\end{array}$} & $0.31 \mathrm{a}$ & $0.47 \mathrm{a}$ & $0.56 \mathrm{a}$ & $0.44 \mathrm{a}$ \\
\hline & $0.35 \mathrm{a}$ & $0.50 \mathrm{a}$ & $0.58 \mathrm{a}$ & $0.47 \mathrm{a}$ \\
\hline & $0.41 \mathrm{a}$ & $0.47 \mathrm{a}$ & $0.68 \mathrm{a}$ & $0.52 \mathrm{a}$ \\
\hline \multirow[t]{2}{*}{ Avg. } & $0.35 \mathrm{~A}$ & $0.48 B$ & $0.60 \mathrm{C}$ & $0.47 \mathrm{~B}$ \\
\hline & \multicolumn{4}{|c|}{ Average, years } \\
\hline \multirow{3}{*}{ 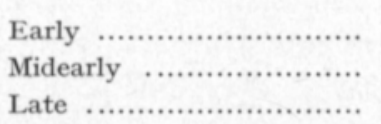 } & $0.63 \mathrm{a}$ & $0.66 \mathrm{a}$ & $\overline{0.79 a}$ & $0.69 \mathrm{a}$ \\
\hline & $0.56 \mathrm{a}$ & $0.69 \mathrm{a}$ & $0.83 a$ & $0.72 \mathrm{a}$ \\
\hline & $0.62 \mathrm{a}$ & $0.71 \mathrm{a}$ & $0.90 \mathrm{a}$ & $0.74 \mathrm{a}$ \\
\hline Avg. & $0.63 \mathrm{~A}$ & $0.68 \mathrm{~A}$ & $0.84 \mathrm{~B}$ & 0.72 \\
\hline
\end{tabular}

L.SD $_{.05}$ Years 0.3

Cuts 0.1 


\subsubsection{Discussion}

Early summer is a forage stand's most effective growth period. The days are long, the radiation level is high, temperatures are favourable and water from melted snow is in abundance for plant use. During midsummer there is enough light and temperature, but a plant's use of resources is often limited because of the lack of available water. In the autumn a stands development is characterized by a reduction in growth as the plants prepare for wintering and the next growing season (RAPPE 1948).

In the selective regression analysis temperature alone accounted for $91.4 \%$ of the variation in spring dry matter production. During the spring light is abundant with regard to the soil and air temperature, and therefore an excessive amount of light in early summer has a negative effect as РонJAKallio (1957) and Valmari (1968) have shown in their investigations. HeinoNEN (1968) confirmed, that light is lost between the beginning of the growing season and the time the stand is dense enough to utilize the light the most effectively.

The midsummer yield formation was most influenced by the precipitation during the week before the previous cut and the amount of rainfall between the cuts. Midsummer of Southern and Southwestern Finland is characterized by a lack of rainfall, while at the same time the evaporation and plant's need for water are greatest (Hooli 1971). If the first cut is delayed in order to obtain a higher DM yield, the gained benefit is lost in the second cut. A positive correlation prevails between the yields of the second and third cuts. This means that a stand must be physiologically active at the time of the second cut in order that a high yield can be obtained from the third and fourth cuts. The deep dormancy of midsummer cannot be broken by the abundant rains of late summer. Pohjakallio and Antila (1955) found that cutting a forage stand during a dry period of the season is very hard on the plants because the cut shoots can remove water from the soil only at a pressure of $1-2$ atmospheres and the soil particles retain it with a noticeably greater pressure.

According to GUTHRIE (1971) the standard calorimetric heat value of fat is $9.45 \mathrm{cal} / \mathrm{mg}$, carbohydrates $4.1 \mathrm{cal} / \mathrm{mg}$ and raw proteins $5.65 \mathrm{cal} / \mathrm{mg}$. The energy values of this investigation of $4.274-4.633 \mathrm{cal} / \mathrm{mg}$ for a clover-grass stand under different treatments and at different times of the growing season illustrate the stand's carbohydrate-fat-protein relationships well. These values include also the differences in the energy values between the low values of midsummer and the high values of spring and autumn.

In 1974 the photosynthetic efficiency of a stand varied between 0.83 and $1.12 \%$ of the available total radiation. The corresponding values for 1975 of $0.31-0.68 \%$ represent for the 4 -cut and 2 -cut systems about one-third and one-half as much respectively of the previous year's values. This fact illustrates the importance of water for assimilation. The obtained assimilation intensity values correspond to $0.77-2.80 \%$ of the amount of visible light. These assimilation values are in the same class as those Hollid Ay (1966) found for barley in England where it was $0.83 \%$ of the total radiation and $2.07 \%$ of the light energy. 


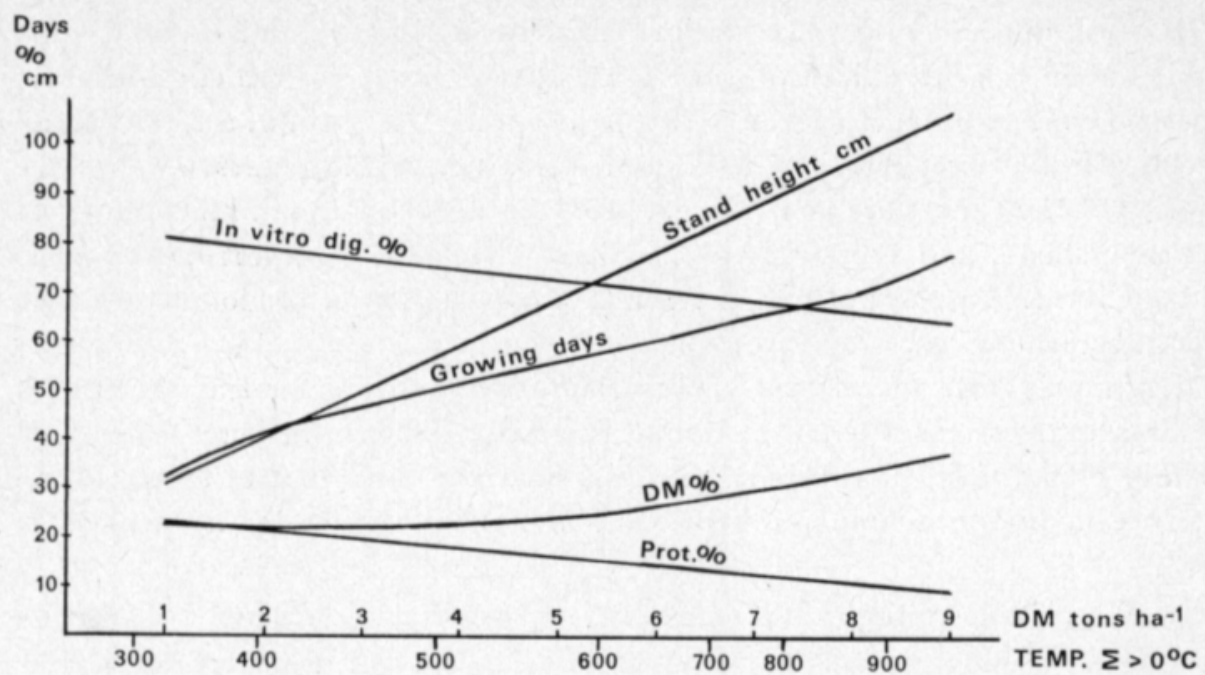

Fig. 6. The quantity and quality changes of clover-grass yield in relation to temperature sum in degeree days $\left(\Sigma>0^{\circ} \mathrm{C}\right)$ in spring growth in $1974-75$.

The growth of a clover-grass stand was most intense during the spring in the temperature sum range of $400-500^{\circ} \mathrm{C}$ (Fig. 6). If the lower limit for the protein content of dry matter is set at $16 \%$, this represents a yield of $5 \mathrm{t} \mathrm{DM}$ $\mathrm{ha}^{-1}$ which has a dry matter content of $24 \%$ and dry matter in vitro digestibility of $73 \%$. For the production of this kind of yield a temperature sum of $575^{\circ} \mathrm{C}$ is needed. When a growth factor, such as water, is a limiting factor then the relationships between growing days and yield components or those between temperature sum and different components of the yield are difficult to determine. The best account is provided by selective regression analysis.

The results obtained show that under normal growing conditions the stands regrowth is better at all cutting frequencies the earlier the first cut is made. These results agree with those of VALLE and Virtanen (1932). On the other hand a late first cut date increased the total yield in the 2- and 3-cut systems, but not always in the 4-cut system where the two middle cuts occurred during the growing season's driest period. These results support those found by Poijärvi (1931) and Teittinen (1959).

\section{2. Characteristics of the stand}

\subsection{Plant height development}

Cultivated forage species follow a sigmoidal curve for height growth. In early stages of development height growth is relatively insignificant and is mainly due to the lengthening of the leaves. The daily increase in height growth is greatest during stem formation following the shooting stage. During flowering height growth slows down and stops in the final stages of flowering. 
HuOKuna et al. (1962) in their investigation of timothy and orchard grass found that in the latter half of June these species daily grow $2 \mathrm{~cm}$ and $4 \mathrm{~cm}$ respectively. According to KELLY (1958) the spring DM yield of a forage stand is most affected by the height and stem formation of the plants because the majority of the shoots are generative. It is typical for plants in midsummer to form new shoots and therefore the height of the stand does not describe the yield by itself. In the autumn neither of these factors is predominant, they both affect the yield.

Mitchell (1956) found that the optimum temperature for leaf growth for cool area grasses was $18-21^{\circ} \mathrm{C}$, where the daily increase in length was $1-5$ $\mathrm{cm}$. The effect of light on height growth is different from that of temperature. A reduction in the amount of light stimulates competition for light and the

Table 8. The influence of first cutting date, growing days and the growing period of the season on the plant height of clover-grass stand cut two, three and four times in 1974-75.

\begin{tabular}{|c|c|c|c|c|c|c|c|c|}
\hline \multirow{2}{*}{$\begin{array}{l}\text { Cutting } \\
\text { system }\end{array}$} & \multirow{2}{*}{\multicolumn{2}{|c|}{$\begin{array}{c}\text { First } \\
\text { Cutting } \\
\text { date }\end{array}$}} & \multicolumn{3}{|c|}{1974} & \multicolumn{3}{|c|}{1975} \\
\hline & & & $\begin{array}{c}\text { Cutting } \\
\text { date }\end{array}$ & $\begin{array}{c}\text { Growing } \\
\text { days }\end{array}$ & $\begin{array}{c}\text { Height } \\
\mathrm{cm}\end{array}$ & $\begin{array}{c}\text { Height } \\
\mathrm{cm}\end{array}$ & $\begin{array}{c}\text { Growing } \\
\text { days }\end{array}$ & $\begin{array}{c}\text { Cutting } \\
\text { date }\end{array}$ \\
\hline \multirow[t]{3}{*}{ 4-cut } & $\mathrm{E}$ & Cut 1. & $3 / 6$ & 39 & 30 & 50 & 39 & $29 / 5$ \\
\hline & M & & $7 / 6$ & 43 & 34 & 51 & 44 & $3 / 6$ \\
\hline & L & & $12 / 6$ & 49 & 46 & 63 & 50 & $9 / 6$ \\
\hline \multirow[t]{3}{*}{ 3-cut } & E & & $17 / 6$ & 53 & 55 & 75 & 54 & $13 / 6$ \\
\hline & M & & $20 / 6$ & 56 & 66 & 82 & 59 & $18 / 6$ \\
\hline & L & & $26 / 6$ & 62 & 79 & 89 & 64 & $23 / 6$ \\
\hline \multirow{3}{*}{ 2-cut } & E & & $1 / 7$ & 67 & 93 & 98 & 68 & $27 / 6$ \\
\hline & M & & $5 / 7$ & 71 & 101 & 102 & 73 & $2 / 7$ \\
\hline & L & & $9 / 7$ & 75 & 102 & 103 & 78 & $7 / 7$ \\
\hline \multirow[t]{3}{*}{ 4-cut } & & Cut 2. & $8 / 7$ & 35 & 81 & 31 & 43 & $11 / 7$ \\
\hline & M & & $12 / 7$ & 35 & 89 & 32 & 43 & $16 / 7$ \\
\hline & L & & $16 / 7$ & 33 & 58 & 33 & 42 & $21 / 7$ \\
\hline \multirow[t]{3}{*}{3 cut } & $\mathrm{E}$ & & $22 / 7$ & 35 & 55 & 28 & 47 & $30 / 7$ \\
\hline & M & & $26 / 7$ & 36 & 50 & 24 & 47 & $4 / 8$ \\
\hline & $\mathrm{L}$ & & $30 / 7$ & 34 & 47 & 18 & 46 & $8 / 8$ \\
\hline \multirow[t]{3}{*}{ 2-cut } & E & & $23 / 8$ & 53 & 69 & 16 & 104 & $10 / 10$ \\
\hline & M & & $26 / 8$ & 52 & 76 & 17 & 100 & $10 / 10$ \\
\hline & L & & $28 / 8$ & 50 & 71 & 19 & 95 & $10 / 10$ \\
\hline \multirow[t]{3}{*}{ 4-cut } & $\mathrm{E}$ & Cut 3. & $12 / 8$ & 35 & 44 & 16 & 42 & $22 / 8$ \\
\hline & M & & $16 / 8$ & 35 & 47 & 17 & 42 & $27 / 8$ \\
\hline & L & & $19 / 8$ & 34 & 57 & 19 & 42 & $1 / 9$ \\
\hline \multirow[t]{3}{*}{ 3-cut } & $\mathrm{E}$ & & $30 / 8$ & 39 & 58 & 14 & 72 & $10 / 10$ \\
\hline & M & & $6 / 9$ & 42 & 68 & 10 & 67 & $10 / 10$ \\
\hline & $\mathrm{L}$ & & $12 / 9$ & 44 & 55 & 8 & 63 & $10 / 10$ \\
\hline \multirow[t]{3}{*}{ 4-cut } & $\mathrm{E}$ & Cut 4. & $23 / 9$ & 42 & 40 & 14 & 49 & $10 / 10$ \\
\hline & M & & $27 / 9$ & 42 & 41 & 11 & 44 & $10 / 10$ \\
\hline & L & & $30 / 9$ & 42 & 36 & 10 & 39 & $10 / 10$ \\
\hline
\end{tabular}


stand's height growth increases (HaN et al. 1977). Height growth will continue to increase until the light intensity reached $50 \%$ of full daylight.

With regard to light utilization it would be important that the stand's assimilative surface be evenly divided throughout the different height levels of the stand. In this way the stand would get equal amounts of light at all levels and the rate of growth at even a small LAI would be greater (WARREN WILSON $1960)$.

\section{Results}

Cut 1

In 1974-75 spring growth followed a normal growth pattern (Table 8). The growing periods were considered to have begun at the time of $0^{\circ} \mathrm{C}$. It can be seen that spring 1975 had the same growing time as in 1974 , but a $67^{\circ} \mathrm{C}$ greater temperature sum during the same time produced a $20 \mathrm{~cm}$ taller stand than in 1974.

The spring's temperature sum, growing time, radiation sum and amount of precipitation correlated strongest with spring height growth (Table 9). The relationships between height growth and growth factors are identical to the correlations between growth factors and dry matter production.

Table 9. The correlation coefficients between growth factors and plant height (cm) in the first, second, third and fourth harvest of clover-grass stand in 1974-76.

\begin{tabular}{|c|c|c|c|c|c|}
\hline \multirow{2}{*}{\multicolumn{2}{|c|}{ Growth factors }} & \multicolumn{4}{|c|}{ Cuts } \\
\hline & & \multirow{2}{*}{$\frac{1 s t}{.96^{* * *}}$} & \multirow{2}{*}{$\frac{2 \mathrm{nd}}{-.49^{* *}}$} & \multirow{2}{*}{$\frac{3 \mathrm{rd}}{-.71 * * *}$} & \multirow{2}{*}{$\frac{4 \text { th }}{-.19 \mathrm{NS}}$} \\
\hline$\Sigma$ days & 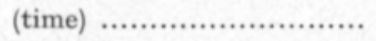 & & & & \\
\hline$\Sigma>0^{\circ} \mathrm{C}$ & 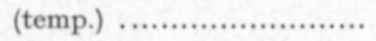 & $.98^{* * *}$ & $-.53 * *$ & $-.80^{* * *}$ & $.53 \mathrm{NS}$ \\
\hline$\Sigma \mathrm{Wh} \mathrm{cm}^{-2}$ & (rad.) .......................... & $.94 * * *$ & $-.32 \mathrm{NS}$ & $-.77^{* * *}$ & $.69 *$ \\
\hline$\Sigma \mathrm{mm}$ & (prec.) .......................... & $.84 * * *$ & $-.03 \mathrm{NS}$ & $-.33 \mathrm{NS}$ & $.82 * * *$ \\
\hline$\Sigma \mathrm{mm}$ & (prec. previous cut) $\ldots . . .$. & & $.87 * * *$ & $.88^{* * *}$ & $.25 \mathrm{NS}$ \\
\hline DM kg ha ${ }^{-1}$ & (previous cut) ................ & & $-.46^{*}$ & $.55^{* *}$ & $.91 * * *$ \\
\hline
\end{tabular}

The highest coefficient of determination, $97.6 \%$, for spring height growth was obtained with the following regression model:

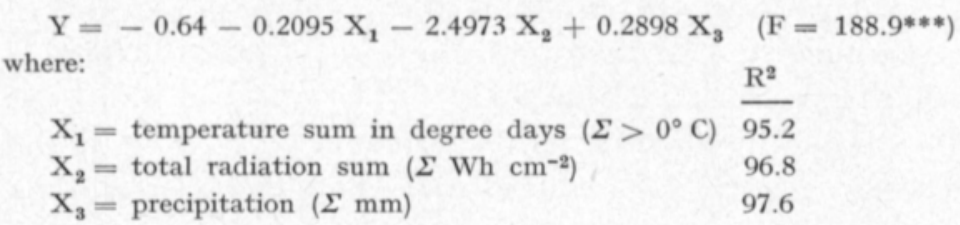

\section{Cut 2}

The stand height growth in the second cut (Table 8), $197447-89 \mathrm{~cm}$ and $197516-33 \mathrm{~cm}$, was mostly dependent on the growing conditions of the period of the growing season, not the growing days. The strongest positive correlation to the amount of precipitation during the week before the previous cut (Table 
9). The disturbances caused by lack of water are illustrated by the negative correlations to temperature sum and growing time. Also the correlation between the height of the first and second cuts was negative.

Within the limit set $(\mathrm{P} \geq 90)$ for the regression analysis of the second cut's height growth only one variable was included in the model, the amount of precipitation during the week before the previous cut. The regression model was as follows:

$$
\begin{aligned}
& \mathrm{Y}=18.22+1.94 \mathrm{X}_{1} \quad\left(\mathrm{~F}=76.78^{* * *}\right) \\
& \mathrm{X}_{1}=\text { precipitation during a week before previous cut }(\mathrm{mm})
\end{aligned} \frac{\mathrm{R}^{2}}{75.4}
$$

\section{Cut 3}

The growth of the third cut in both the 3- and 4-cut systems occurred during the growing season's driest period. A stand had a very big chance of going into dormancy which would last for the rest of the growing season. Because of this, almost no stand height growth occurred (Table 8). The correlation between the growth factors and height growth (Table 9) was completely identical to that between the growth factors and dry matter yield (Table 2). Height growth had a positive correlation to the amount of precipitation during the week before the previous cut and the previous cut's yield. Height growth would also require an active physiological state to exist at the time of the second cut.

In the selective regression analysis water decisively influenced midsummer height growth. The regression model was as follows:

$$
\mathrm{Y}=-7.12+1.7530 \mathrm{X}_{1}+0.1719 \mathrm{X}_{2} \quad\left(\mathrm{~F}=36.63^{* * *}\right)
$$
where:

$$
\begin{array}{ll}
\mathrm{X}_{1}=\text { precipitation during a week before previous cut }(\Sigma \mathrm{mm}) & \frac{\mathrm{R}^{2}}{76.7} \\
\mathrm{X}_{2}=\text { precipitation between cuts }(\Sigma \mathrm{mm}) & 80.3
\end{array}
$$

\section{Cut 4}

Growth factors weaken as autumn approaches. At the same time the midsummer drought can reduce plant metabolic activity to such a low level that it may be difficult for the plant to recover. The autumn growth of a clover-grass stand is best correlated to the previous cut's yield, precipitation sum and amount of light. Because of growth factors, autumn height growth does not transfer to a generative stage, and this results in low stem production which means limited height growth (Table 8).

The highest coefficient of determination, $99.4 \%$, from the selective regression analysis of autumn height growth was obtained with the following regression model:

$$
\mathrm{Y}=3.72+0.2711 \mathrm{X}_{1}+7.5042 \mathrm{X}_{2}-0.1641 \mathrm{X}_{3} \quad\left(\mathrm{~F}=108.69^{* * *}\right)
$$
where:

$$
\begin{aligned}
& \mathrm{X}_{1}=\text { precipitation between cuts }(\Sigma \mathrm{mm}) \quad \frac{\mathrm{R}^{2}}{96.3} \\
& \mathrm{X}_{2}=\text { total radiation sum }\left(\Sigma \mathrm{Wh} \mathrm{cm}^{-2}\right) \quad 98.4 \\
& \mathrm{X}_{3}=\text { temperature sum in degree days }\left(\Sigma>0^{\circ} \mathrm{C}\right) 99.4
\end{aligned}
$$




\section{2. 2. Dry matter content of the stand}

In young plants the cells are full of cytoplasm. Also, the cell walls contain abundant amounts of water (KRAMER 1959). As the plant develops the cell walls thicken and dry matter increases in the leaves. When a plant ages the amount of lignin in the plant increases and the total dry matter content of the yield is raised also.

In addition to the growth stage also weather conditions such as rain, dew, wind and the amount of radiation greatly affect the dry matter content of a forage stand (SYRJÄLÄ 1973, Salo et al. 1975). During dry periods of the growing season the dry matter content of a forage yield increases rather strongly as the stand's growth progresses. According to Poutiainen and Rinne (1971) the dry matter content of a meadow fescue-timothy stand at a 3-4 leaf stage was $20.5 \%$, at the beginning of heading $21.1 \%$, during heading $22.3 \%$ and at the beginning of flowering $28.5 \%$.

The increase in a plant's dry matter content is closely associated with the increase in its fiber content. SYRJ ̈̈L fescue that at the end of May the raw protein content was $20.6 \%$ of the dry matter and by June 20th the fiber content had already risen to $31.2 \%$. The longer the interval between cuts the greater the fiber and dry matter contents (HUOKUNA 1964).

\section{Results}

The dates of the first cuts and the dry matter contents of the yields are shown in Fig. 7. In 1974 the dry matter content in the 4-cut system decreased until June 12th because of the relatively young stage of development. After this date the dry matter content began to rise to a level of $27.2 \%$, the same as what existed in the late cut of the 2-cut system. In 1975 the stand's early growth by May 29, the first cutting, date of the 4-cut system, had already passed the wettest development stage, and this caused the dry matter content of the first cuts to increase from $22.9 \%$ to $40.4 \%$ which was the dry matter level in the late first cut of the 2-cut system made on July 7th. DM contents in 1974 and 1975 described very clearly the importance of the developmental stage of the stand and of water as a growth factor (Fig. 7).

The dry matter content in the total yields of 1974 decreased as the first cutting date was delayed in the 4-cut system and increased in the 3 - and 2-cut systems (Table 10). The very rapid stand development before the first cut in the spring of 1975 and then the lack of water during the midsummer caused the dry matter content to rise in all of the delayed first cuts in all of the cutting systems (Table 10).

The relationships between the growth factors and the development of the dry matter content for the period $1974-76$ were as follows:

\section{Cut 1}

In spring growth the development of dry matter content was mostly correlated to the temperature sum in degree days (Table 11). There were also statistically significant positive correlations between the dry matter content and the growing time and radiation sum. 

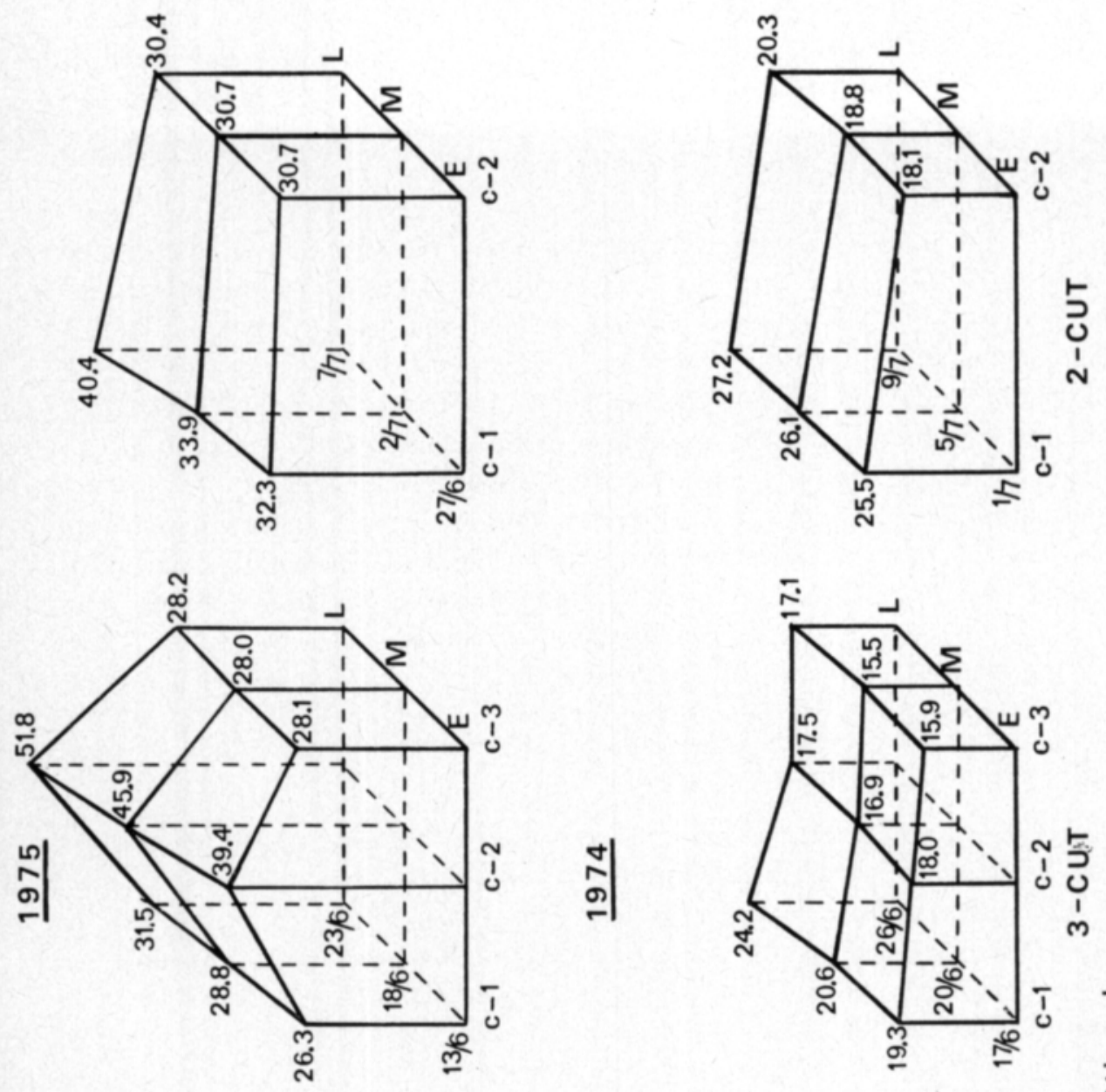

\pm
0
$\sigma$
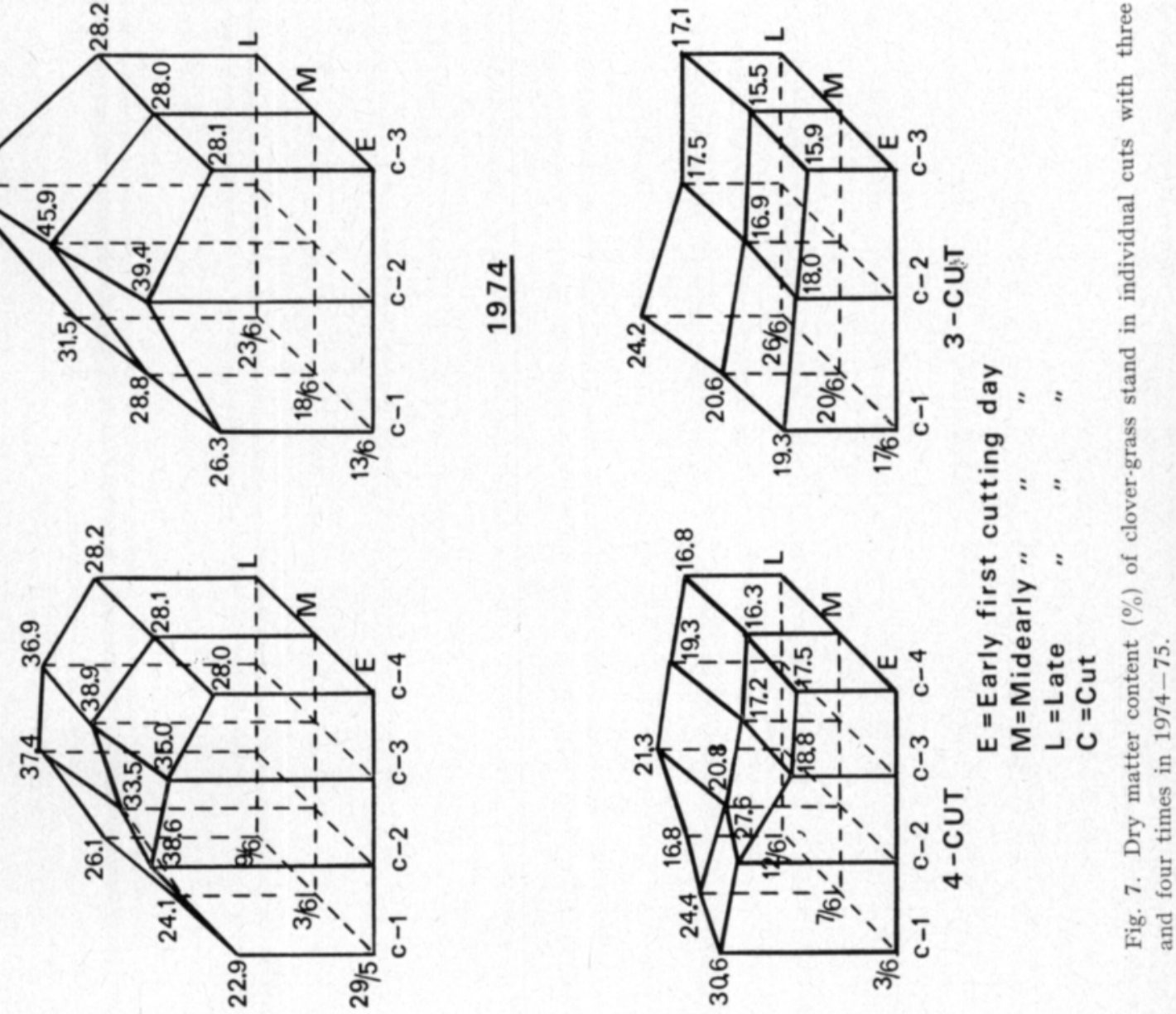
Table 10. Dry matter content ( $\%$ DM) of clover-grass stand with three different first-cutting dates, harvested two, three and four times per season in 1974-75.

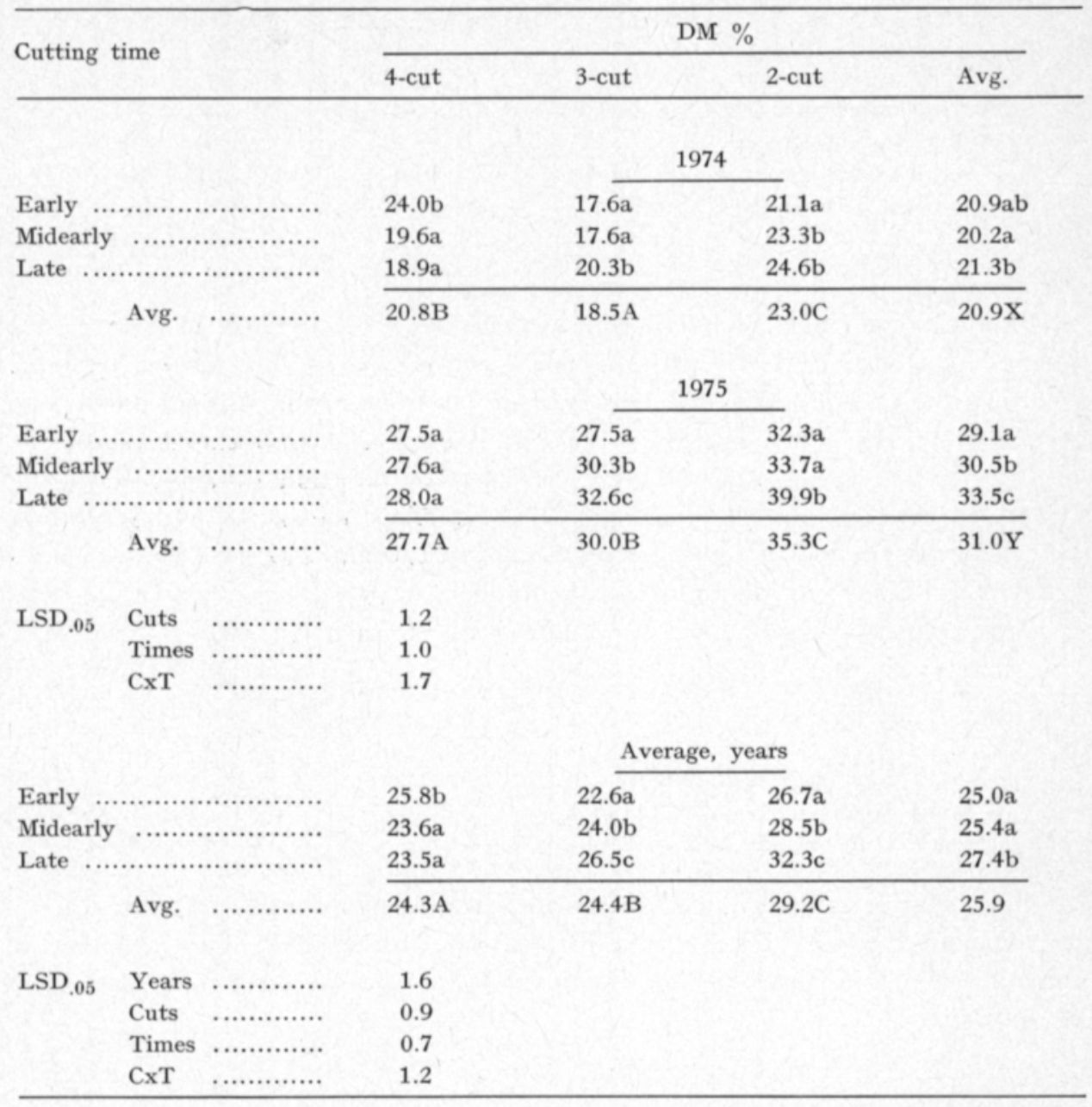

Table 11. The correlation coefficients between growth factors and DM $\%$ in the first, second, third and fourth harvest of a clover-grass stand in 1974-76.

\begin{tabular}{|c|c|c|c|c|c|}
\hline \multirow{2}{*}{\multicolumn{2}{|c|}{ Growth factors }} & \multicolumn{4}{|c|}{ Cut } \\
\hline & & 1st & 2nd & $3 \mathrm{rd}$ & 4th \\
\hline$\Sigma$ days & 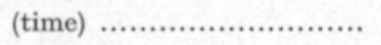 & $.60^{* *}$ & $.17 \mathrm{NS}$ & $.23 \mathrm{NS}$ & $.35 \mathrm{NS}$ \\
\hline$\Sigma>0^{\circ} \mathrm{C}$ & (temp.) ….................... & $.65^{* *}$ & $.23 \mathrm{NS}$ & $.43^{*}$ & $-.40 \mathrm{NS}$ \\
\hline$\Sigma \mathrm{Wh} \mathrm{cm}^{-2}$ & 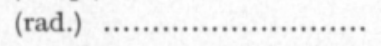 & $.59^{* *}$ & $.57 * *$ & $.55^{* *}$ & $-.55 \mathrm{NS}$ \\
\hline$\Sigma \mathrm{mm}$ & (prec.) ........................ & $.14 \mathrm{NS}$ & $-.57 * *$ & $-.22 \mathrm{NS}$ & $-.92 * * *$ \\
\hline$\Sigma \mathrm{mm}$ & (prec. previous cut) ........ & & $-.43^{*}$ & $-.58 * *$ & $-.17 \mathrm{NS}$ \\
\hline DM kg ha $\mathrm{h}^{-1}$ & (previous cut) ............... & & $.09 \mathrm{NS}$ & $-.61 * *$ & $-.96 * * *$ \\
\hline
\end{tabular}


The high coefficient of determination of $94.9 \%$ was obtained through selective regression analysis with the following regression model:

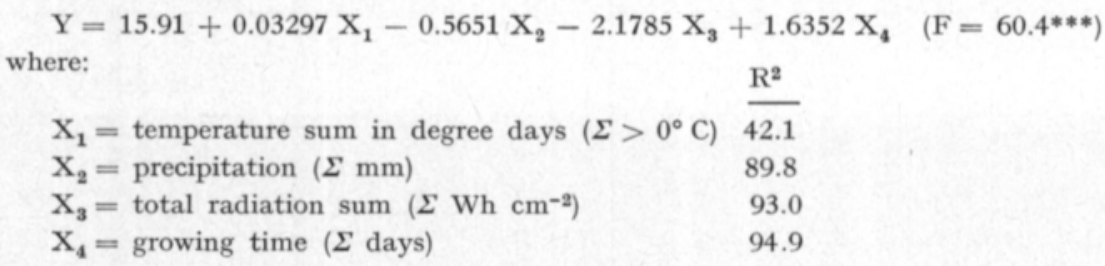

\section{Cut 2}

In the second cuts of all cutting systems only the amount of light had a positive correlation to the development of the yield's dry matter content.

Both the precipitation sum between cuts and amount of rainfall during the week before the previous cut had negative correlations to the development of dry matter content. The coefficient of determination obtained with the selective regression model was only $77.3 \%$. This means that the residual percentage in the model contained elements of the stand's DM content development which were not included in the model.

The regression model was as follows:

$\mathrm{Y}=29.66-0.7074 \mathrm{X}_{1}-0.3809 \mathrm{X}_{2}+0.04941 \mathrm{X}_{3} \quad\left(\mathrm{~F}=26.08^{* * *}\right)$ where:

$$
\begin{array}{ll}
\mathrm{X}_{1}=\text { total radiation sum }\left(\Sigma \mathrm{Wh} \mathrm{cm}-{ }^{2}\right) & \overline{32.8} \\
\mathrm{X}_{2}=\text { precipitation between cuts }(\Sigma \mathrm{mm}) & 55.8 \\
\mathrm{X}_{3}=\text { temperature sum in degree days }\left(\Sigma>0^{\circ} \mathrm{C}\right) & 77.3
\end{array}
$$

The negative influence of the radiation sum in the model is probably due to the dormancy caused by the combined effects of the drought and abundant sunshine, which in turn affected the loss of apical dominance and the onset of shooting.

\section{Cut 3}

In the third cut both the temperature and radiation sums had statistically significant positive correlations with the development of DM content (Table 11). The previous cut's productivity and the amount of rainfall the week before the previous cut had negative correlations to the DM content development.

The regression model was as follows:

$$
\mathrm{Y}=24.56-0.001325 \mathrm{X}_{1}-0.2458 \mathrm{X}_{2}+0.031633 \mathrm{X}_{3} \quad\left(\mathrm{~F}=20.40^{* * *}\right)
$$
where:

$$
\begin{array}{ll}
\mathrm{X}_{1}=\text { DM yield in previous cut }\left(\mathrm{kg} \mathrm{ha}^{-1}\right) & \overline{36.9} \\
\mathrm{X}_{2}=\text { precipitation between cuts }(\Sigma \mathrm{mm}) & 48.5 \\
\mathrm{X}_{3}=\text { temperature sum in degree days }\left(\Sigma>0^{\circ} \mathrm{C}\right) & 78.3
\end{array}
$$

During the driest growing period during midsummer the stand's physiological state in the previous cut combined with the temperature determined the development of the dry matter content. 
The fourth cut represents the part of the growing season where there are very few quality changes because of the weakening of growth factors. The amount of the yield in the previous cut and the amount of precipitation the cut received had statistically significant negative correlations to the later summer's dry matter content development (Table 11).

The regression model used in the selective regression analysis of the autumn growth's dry matter content was the following:

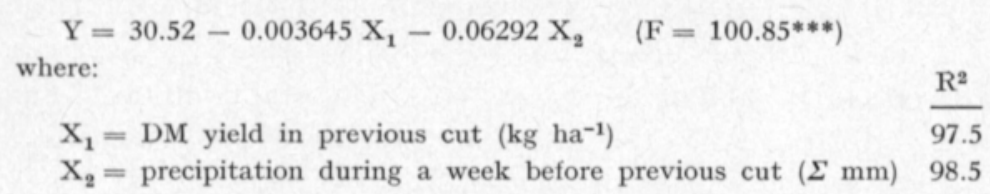

The factors obtained accounted for $98.5 \%$ of those that influenced the autumn dry matter content. Of particular significance is the important role water plays in the formation of the late autumn yield and its quality.

\subsection{Protein content of the dry matter}

As the stand ages the composition and feeding value of the forage changes. All of the changes are unfavourable from the nutrition value point of view (PoIJÄrvi 1955). PoIJÄrvi's (1955) clover-timothy plots in Tikkurila produced dry matter yields with raw protein contents of $14.2,8.7$ and $7.2 \%$ during the timothy stages of heading, early flowering and late flowering respectively. As the plants develop the amount of nitrogen free components such as cellulose and lignin increase at the expense of raw protein.

The rate of growth influences the protein content of the forage stand. SALO (1976) found that the exceptionally warm weather in the spring of 1970 increased the rate of growth and rapidly decreased the protein content. As part of the same investigation the chilly, wet spring of 1972 lowered the raw protein content slowly when the rate of growth was less. When grass grows slowly its protein content remains low because at a certain stage of development the plant is physiologically older than one that grew quickly (GiöBEL and Steen 1964, Salo et al. 1975). Poutiainen and Rinne (1976) found that during the period June 4 - June 25 the protein content decreased by 0.62 percentage units a day. In SYRJÄLÄ's (1974) investigation the raw protein content decreases by 0.8 percentage units within the first two weeks of June. SAlo et al. (1975) found the decrease to be over 1.0 percentage units a day.

Because a young forage stand contains more protein than an old one, the protein content of the yields increases as the number of cuts increases. The autumn yield usually has not developed as much as a spring yield and therefore contains more protein than the spring yield.

\section{Results}

In 1974 the protein content of the clover-grass stand in the 4-cut system decreased during the period of the first cut June 3-12 from 27.5 to $22.1 \%$. This decrease represents a daily loss of $0.6 \%$-units (Fig. 8, Table 12). For 
the 3-cut system the first cuts were made during June $12-26$ and the drop in protein content over this period was $0.6 \%$-units a day. In July the new growth due to shooting affected the raw protein content in the 2-cut system. The resulting decrease was $0.21 \%$-units a day. In 1975 the changes were $0.28 \%$ -units and $0.32 \%$-units respectively. The decrease in the 2 -cut system was the same as it was in 1974 (Fig. 8.) Changes in the protein content of the primary growth were few after the beginning of July (Fig. 8). The second cuts (Fig. 8, Table 12) in the different cutting systems were made during June 3 - August 28 and the daily decrease in protein content in the 3 - and 4-cut systems about $2-3$ weeks before cutting was $0.15-0.29 \%$-units. The 2 -cut system showed a decrease of $0.03 \%$-units per day. The stand in the 2-cut system was at a very late stage of development at the time of the second cut, as a protein content of $10.2 \%$ illustrates (Fig. 9).

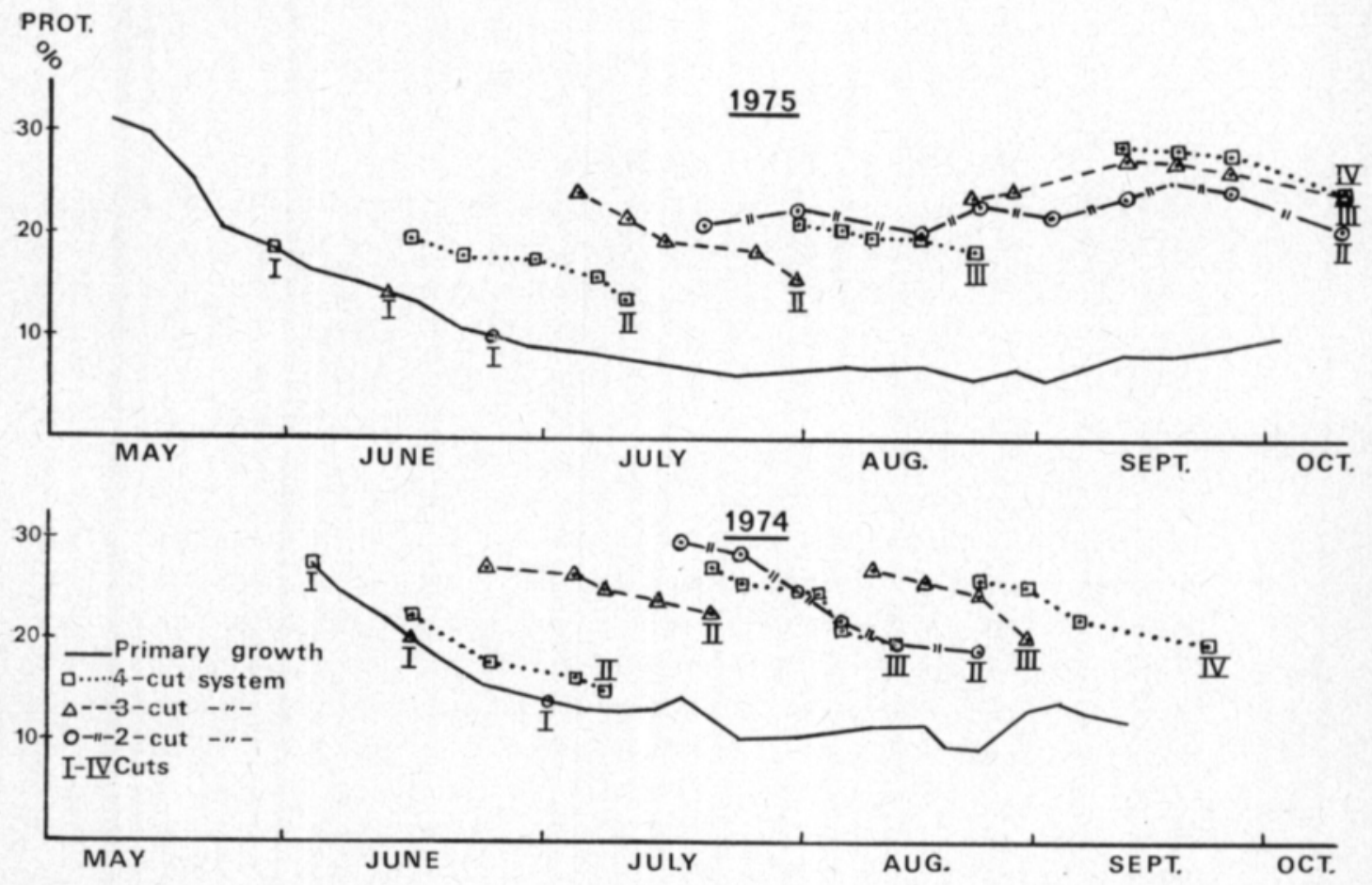

Fig 8. Protein content development ( $\%$ in $\mathrm{DM})$ of clover-grass stand in primary growth and between individual cuts harvested two, three and four times in 1974-75.

The third cuts in 1974 of the 3- and 4-cut systems were made during July 8 - September 12. The raw protein decrease of $0.40-0.44 \%$-units in the stand $2-3$ weeks before the cut indicated favorable growing conditions and vigorous growth (Fig. 8, Table 12). In 1975 the dormancy at the time of the 3-cut system's third cut was broken when the autumn rains began. New shoot growth always increased the stand's protein content until the middle of September (Fig. 8). Beyond this time the decrease in protein content was 0.16 

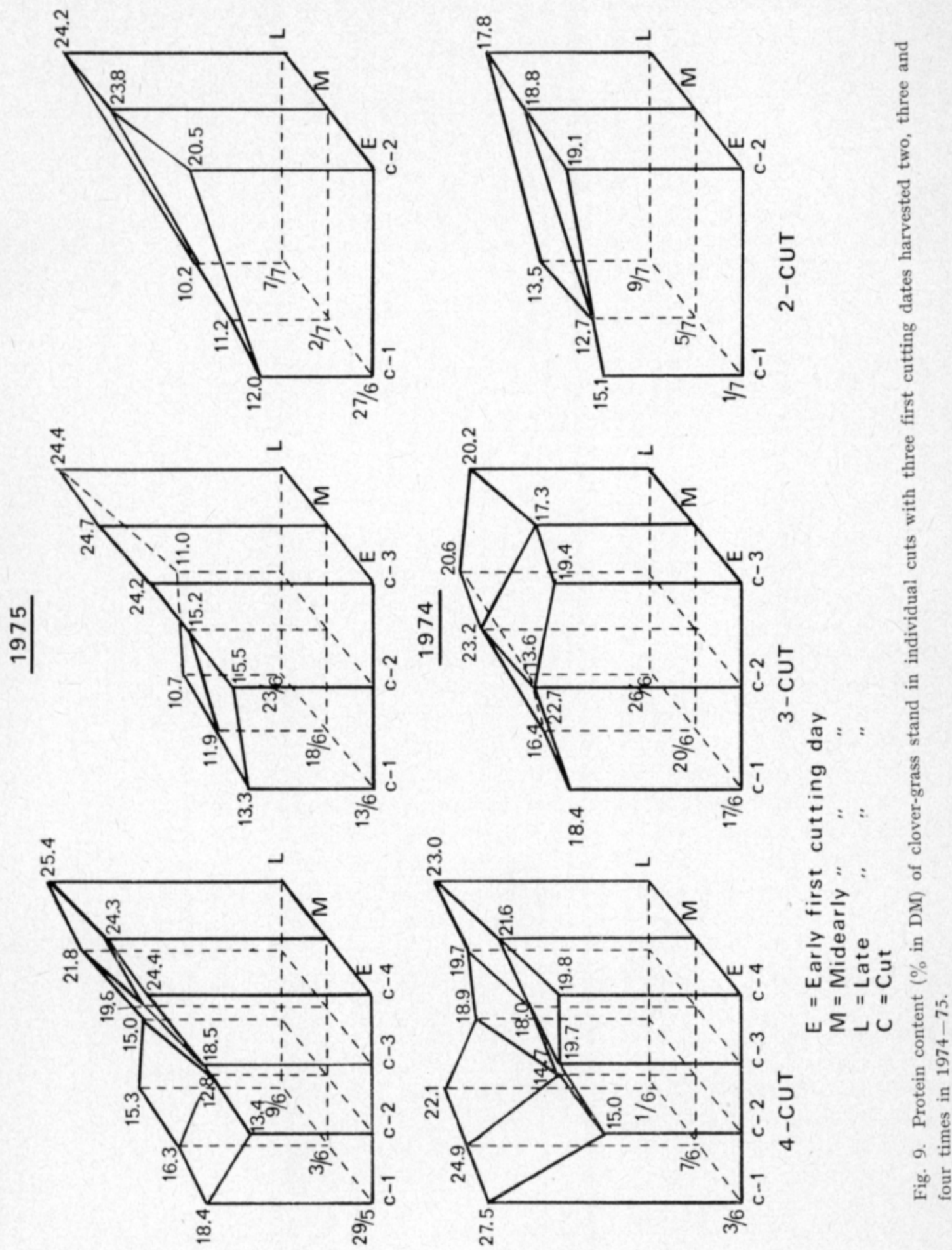
Table 12. The decrease of protein content in DM of clover-grass stand in the first, second, third and fourth harvest during a certain time period in $1974-75$.

\begin{tabular}{|c|c|c|c|c|c|c|c|c|}
\hline \multirow{3}{*}{$\begin{array}{l}\text { Cutting } \\
\text { system }\end{array}$} & \multicolumn{8}{|c|}{ Decrease $\%$ protein content/time period } \\
\hline & \multicolumn{2}{|c|}{ Cut 1.} & \multicolumn{2}{|c|}{ Cut 2.} & \multicolumn{2}{|c|}{ Cut 3 . } & \multicolumn{2}{|c|}{ Cut 4.} \\
\hline & Time & $\%$ & Time & $\%$ & Time & $\%$ & Time & $\%$ \\
\hline
\end{tabular}

1974

$\begin{array}{lllllllll}4 \text { cut } & (3 / 6-12 / 6) & 0.60 & (26 / 6-8 / 7) & 0.25 & (30 / 7-12 / 8) & 0.44 & (30 / 8-23 / 9) & 0.22 \\ 3 \text { cut } & (12 / 6-26 / 6) & 0.60 & (8 / 7-22 / 7) & 0.15 & (12 / 8-30 / 8) & 0.40 & & \\ 2 \text { cut } & (26 / 6-9 / 7) & 0.21 & (22 / 7-23 / 8) & 0.29 & & & & \end{array}$

\begin{tabular}{lllllllll}
4 cut & $(29 / 5-9 / 6)$ & 0.28 & $(19 / 6-11 / 7)$ & 0.27 & $(30 / 7-22 / 8)$ & 0.10 & $(11 / 9-10 / 10)$ & 0.16 \\
3 cut & $(9 / 6-23 / 6)$ & 0.32 & $(11 / 7-30 / 7)$ & 0.30 & $(11 / 9-10 / 10)$ & 0.16 & \\
2 cut & $(23 / 6-7 / 7)$ & 0.20 & $(1 / 9-10 / 10)$ & 0.03 & & & & \\
\hline
\end{tabular}

$\%$-units per day (Table 12). The dormant state of the stand during the third cut in the 4-cut system caused a mild reduction of $0.10 \%$-units per day in the raw protein content of the stand (Table 12). Because of the weakening of growth factors in the autumn a plant accumulates mainly sugars. Delaying the first cut in the 2-cut system raised the yield in both cuts. The higher level resulted from the lower protein content of the dry matter (Fig. 4, Fig. 9).

The raw protein content in the first cut of 1975 followed the same trend as in 1974 (Fig. 9). At the time of the second cuts in the 3- and 4-cut systems there was severe dormancy and low protein content. Because of the dormancy apical dominance was lost and in the following summer and autumn cuts the regrowth was insignificant with relatively high protein content in the short new shoots (Fig. 9). The total yields for both 1974 and 1975 contain negative correlations between raw protein contents in DM and dry matter yields (Table 13, Table 5). During 1974 the average raw protein content in the 3- and 4-cut systems was the same, and that for the 2-cut system was $3 \%$-units lower. 1975 the 2- and 3-cut systems were not statistically different from each other. They also had about a $4 \%$-units lower protein content than the average protein content for the 4-cut system (Table 13).

The relationships between the growth factors and the changes in the protein content in DM were investigated during 1974-76. The results were analyzed with selective regression models.

\section{Cut 1}

The DM protein content of the spring growth strongly correlated with all of the growth factors investigated. The strongest negative correlation, $-0.85^{* * *}$ (Table 14), was between the raw protein content and the spring temperature sum. 
Table 13. Protein content $\%$ in DM of grass-clover stand with three different first-cutting dates harvested, two, three and four times per season in 1974-75.

\begin{tabular}{lllll}
\hline \multirow{2}{*}{ Cutting time } & \multicolumn{4}{l}{ Protein $\%$ in DM } \\
\cline { 2 - 5 } & 4-cut & 3-cut & 2-cut & Avg. \\
\hline
\end{tabular}

\begin{tabular}{|c|c|c|c|c|}
\hline \multirow[b]{2}{*}{ 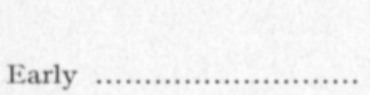 } & \multicolumn{2}{|c|}{1974} & \multirow[b]{2}{*}{$16.8 \mathrm{~b}$} & \multirow[b]{2}{*}{$18.4 \mathrm{~b}$} \\
\hline & $18.2 \mathrm{a}$ & $20.2 \mathrm{~b}$ & & \\
\hline Midearly ........................ & $17.8 \mathrm{a}$ & $18.1 \mathrm{a}$ & $15.1 \mathrm{a}$ & $17.0 \mathrm{a}$ \\
\hline Late & $20.6 \mathrm{~b}$ & $17.1 \mathrm{a}$ & $15.2 \mathrm{a}$ & $17.6 \mathrm{a}$ \\
\hline Avg. ............ & 18.7B & $18.5 \mathrm{~B}$ & $15.7 \mathrm{~A}$ & $17.7 \mathrm{X}$ \\
\hline
\end{tabular}

\begin{tabular}{|c|c|c|c|c|c|}
\hline \multirow{2}{*}{\multicolumn{2}{|c|}{ Early $\ldots \ldots \ldots \ldots \ldots \ldots \ldots \ldots \ldots \ldots \ldots$}} & \multicolumn{2}{|c|}{1975} & \multirow[b]{2}{*}{$12.3 \mathrm{a}$} & \multirow[b]{2}{*}{$14.4 \mathrm{c}$} \\
\hline & & $17.1 \mathrm{~b}$ & $13.8 \mathrm{c}$ & & \\
\hline Midearly & (...................... & $15.7 \mathrm{a}$ & $12.1 \mathrm{~b}$ & $12.0 \mathrm{a}$ & $13.3 \mathrm{~b}$ \\
\hline \multirow[t]{2}{*}{ Late ... } & ………………… & $15.5 \mathrm{a}$ & $10.8 \mathrm{a}$ & $11.1 \mathrm{a}$ & $12.5 \mathrm{a}$ \\
\hline & Avg. $\quad \ldots \ldots \ldots \ldots \ldots$ & $16.1 \mathrm{~B}$ & $12.2 \mathrm{~A}$ & $11.8 \mathrm{~A}$ & $13.4 \mathrm{Y}$ \\
\hline \multirow[t]{3}{*}{$\mathrm{LSD}_{.05}$} & Cuts $\quad \ldots \ldots \ldots \ldots \ldots$ & 1.1 & & & \\
\hline & Times .............. & 0.8 & & & \\
\hline & CxT & 1.3 & & & \\
\hline
\end{tabular}

\begin{tabular}{|c|c|c|c|c|c|c|}
\hline \multirow{2}{*}{\multicolumn{3}{|c|}{ Early }} & \multicolumn{2}{|c|}{ Average, years } & \multirow[b]{2}{*}{$14.6 \mathrm{~b}$} & \multirow[b]{2}{*}{$16.4 \mathrm{~b}$} \\
\hline & & & $17.7 \mathrm{ab}$ & $17.0 \mathrm{c}$ & & \\
\hline Midearl & .......... & …............ & $16.8 \mathrm{a}$ & $15.1 \mathrm{~b}$ & $13.6 \mathrm{a}$ & $15.2 \mathrm{a}$ \\
\hline \multirow[t]{2}{*}{ Late.. } & ............. & ................. & $18.1 \mathrm{~b}$ & $14.0 \mathrm{a}$ & $13.2 \mathrm{a}$ & $15.1 \mathrm{a}$ \\
\hline & Avg. & ……........ & $17.5 \mathrm{C}$ & $15.4 \mathrm{~B}$ & $13.8 \mathrm{~A}$ & 15.6 \\
\hline \multirow[t]{4}{*}{$\mathrm{LSD}_{.05}$} & Years & …............ & 4.2 & & & \\
\hline & Cuts & ……....... & 0.8 & & & \\
\hline & Times & ............... & 0.5 & & & \\
\hline & $\mathrm{CxT}$ & …............ & 0.9 & & & \\
\hline
\end{tabular}

Table 14. The correlation coefficients between growth factors and protein content $\%$ in DM in the first, second, third and fourth harvest of a clover-grass stand in 1974-76.

\begin{tabular}{|c|c|c|c|c|c|}
\hline \multirow{2}{*}{\multicolumn{2}{|c|}{ Growth factors }} & \multicolumn{4}{|c|}{ Cuts } \\
\hline & & \multirow{2}{*}{$\begin{array}{c}1 \mathrm{st} \\
-.82^{* * * *}\end{array}$} & \multirow{2}{*}{$\begin{array}{l}\text { 2nd } \\
.28 \mathrm{NS}\end{array}$} & \multirow{2}{*}{$\begin{array}{l}3 \mathrm{rd} \\
.94 * * *\end{array}$} & \multirow{2}{*}{$\begin{array}{l}\text { 4th } \\
.14 \mathrm{NS}\end{array}$} \\
\hline$\Sigma$ days & 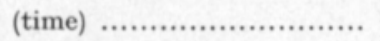 & & & & \\
\hline$\Sigma>0^{\circ} \mathrm{C}$ & 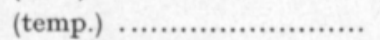 & $-.85 * * *$ & $.25 \mathrm{NS}$ & $.90 * * *$ & $-.29 \mathrm{NS}$ \\
\hline$\Sigma \mathrm{Wh} \mathrm{cm}^{-2}$ & (rad.) …....................... & $-.78 * * *$ & $-.40^{*}$ & $.74 * * *$ & $-.51 \mathrm{NS}$ \\
\hline$\Sigma \mathrm{mm}$ & 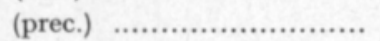 & $-.77 * * *$ & $.79 * * *$ & $.75 * * *$ & $-.33 \mathrm{NS}$ \\
\hline$\Sigma \mathrm{mm}$ & (prec. previous cut) .......... & & $-.19 \mathrm{NS}$ & $-.88 * * *$ & $-.51 \mathrm{NS}$ \\
\hline DM kg ha-1 & (previous cut) ......................... & & $.29 \mathrm{NS}$ & $-.39 \mathrm{NS}$ & $-.46 \mathrm{NS}$ \\
\hline
\end{tabular}


The highest coefficient of determination, $87.4 \%$, was obtained with the following regression model:

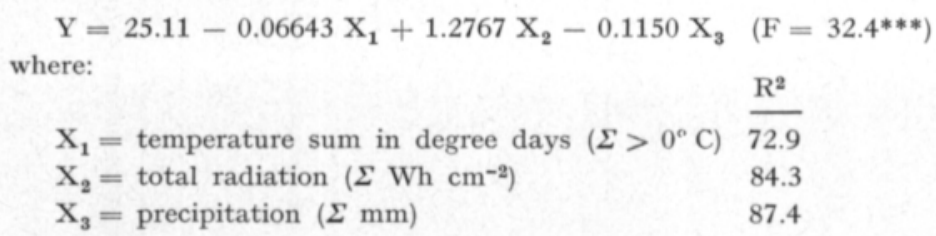

Both temperature and water stimulated growth and reduced the protein content. Radiation had the effect of restraining the reduction in protein content and this was probably due to the same phenomenon as observed in dry matter production.

\section{Cut 2}

In the second cut the protein content was positively correlated to the amount of precipitation for the cut. This reflects the slow changes in the quality of the yield, if water is available. The negative correlation to the radiation sum meant sunny weather, low precipitation and a quick reduction in the quality of the yield. The regression model used was:

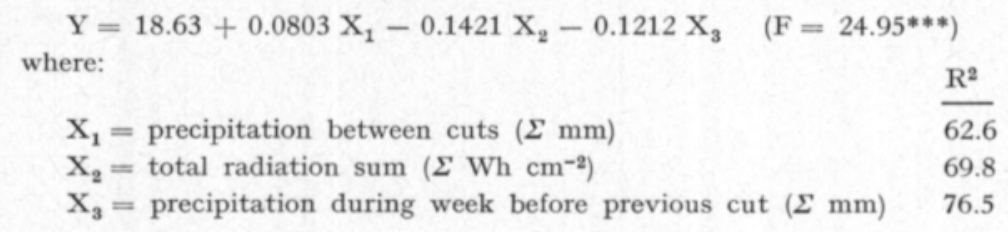

\section{Cut 3}

The correlation between growth factors and the protein content of the yield for the third cut in the 4-cut system was strongly influenced by the loss of apical dominance and the limited shoot growth caused by the dry growing conditions in 1975. The auxiliary shoot growth resulted in a high protein content. The same trend was found in 1974 , but to a slightly milder degree. As the third cut is always made late in the autumn the changes in protein content are slow. The growing period's temperature sum, radiation and amount of precipitation all were positively correlated and the stand's physiological activity had a negative correlation (Table 14).

In the regression equation only the temperature sum and radiation sum fit into the model which described the changes in the protein content of the third cut. The model was as follows:$$
\mathrm{Y}=18.59+0.03036 \mathrm{X}_{1}-1.09275 \mathrm{X}_{2} \quad\left(\mathrm{~F}=125.76^{* * *}\right)
$$
where:$$
\begin{array}{ll}
\mathrm{X}_{1}=\text { temperature sum in degree days }\left(\Sigma>0^{\circ} \mathrm{C}\right) & \frac{\mathrm{R}^{2}}{81.5} \\
\mathrm{X}_{2}=\text { total radiation sum }\left(\Sigma{\left.\mathrm{Wh} \mathrm{cm}^{-2}\right)}^{93.3}\right.
\end{array}
$$ 
No statistically significant direct correlations were obtained for the autumn cut (Table 14). Nevertheless, it can be seen that an increase in light caused a rapid rise in development and a decrease in the protein content. The following regression model described $100 \%$ of the changes in protein content:

$$
\begin{aligned}
& \mathrm{Y}=23.23-2.3949 \mathrm{X}_{1}+0.04887 \mathrm{X}_{2}-0.000429 \mathrm{X}_{3}+0.0215 \mathrm{X}_{4} \quad\left(\mathrm{~F}=2025.7^{* * *}\right) \\
& \text { where: } \\
& \begin{array}{ll}
\mathrm{X}_{1}=\text { total radiation sum }\left(\Sigma \mathrm{Wh} \mathrm{cm}^{-2}\right) & \multicolumn{1}{l}{\mathrm{R}^{2}} \\
\mathrm{X}_{2}=\text { temperature sum in degree days }(\Sigma>0.6 & 90.2 \\
\mathrm{X}_{3}=\text { DM yield in previous cut }\left(\mathrm{kg} \mathrm{ha}^{-1}\right) & 99.5 \\
\mathrm{X}_{4}=\text { precipitation between cuts }(\Sigma \mathrm{mm}) & 100.0
\end{array}
\end{aligned}
$$

As can be seen from the regression model light, temperature, the stand's physiological activity and the amount of precipitation influence the development of the protein content in the autum.

\section{2. 4. Cellulase digestibility of dry matter}

As a plant ages its digestibility decreases. The decrease in digestibility continues even after the increase in fiber content stops. This decrease is because of the increase in the lignin and xylan concentrations (SALO et al. 1975).

The rate at which changes occur in plant digestibility depends on the different stages of plant development and the growing conditions of the summer. Changes in digestibility during the spring are very fast. The more frequent a stand is cut the more digestible is the forage because young grass is more digestible than old grass (Huokuna 1973). TILley et al. (1960-64) observed that the in vitro digestibility of forage plants decreased slowly until the point of panicle. Pritchard et al. (1963) found with forage that its digestibility decreased $0.5 \%$-units per day during the growing period. The fastest decrease in digestibility came immediately after the emergence of panicle. According to WALTERS et al. (1967) periodic changes in digestibility occur up to the time of the first cut. The digestibility of the first cut is determined by the plant species, stage of development and the ratio of green leaves to stems.

Mowat et al. (1965) also stated that the stems of young plants are more digestible than the leaves. In Finland Raininko (1973) has investigated the in vitro digestibility of timothy, meadow fescue and orchard grass. The digestibility of orchard grass was poorer than that of timothy and meadow fescue. According to OLDER and Linnutaja (1976) the order of the three species according to decreasing digestibility is meadow fescue, timothy and orchard grass.

GUEDAS et al. (1970) studied the in vitro digestibility of pasture grass. In the first cut the digestibility was 73.5 , but only $62.6 \%$ in the third. According to Cubillos et al. (1970) the digestibility of a rye grass-clover stand decreased in four months from $82 \%$ to $38 \%$. 

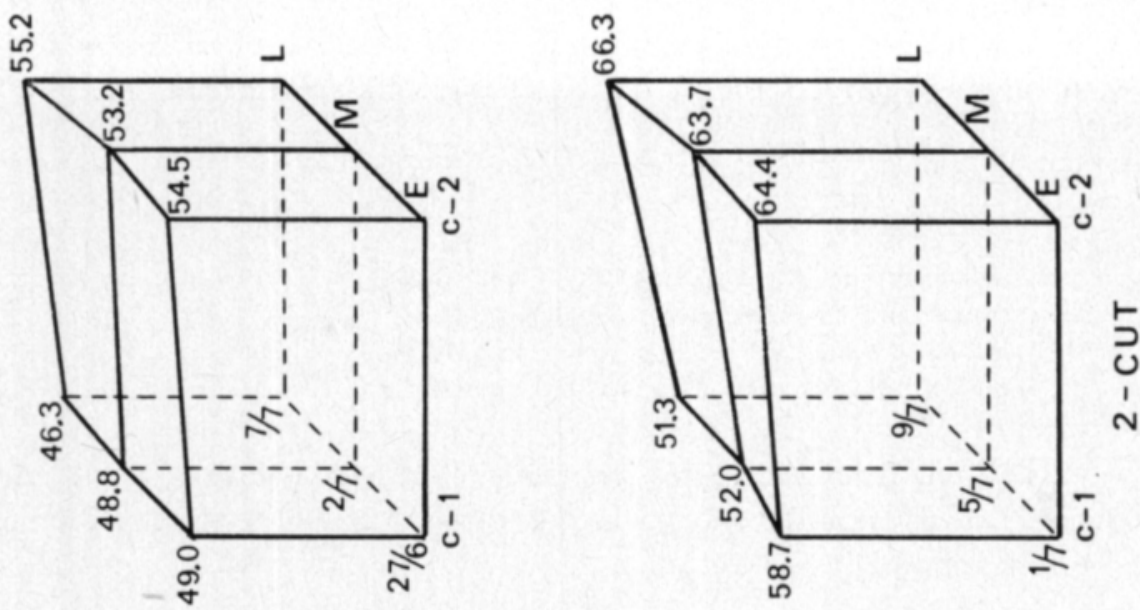


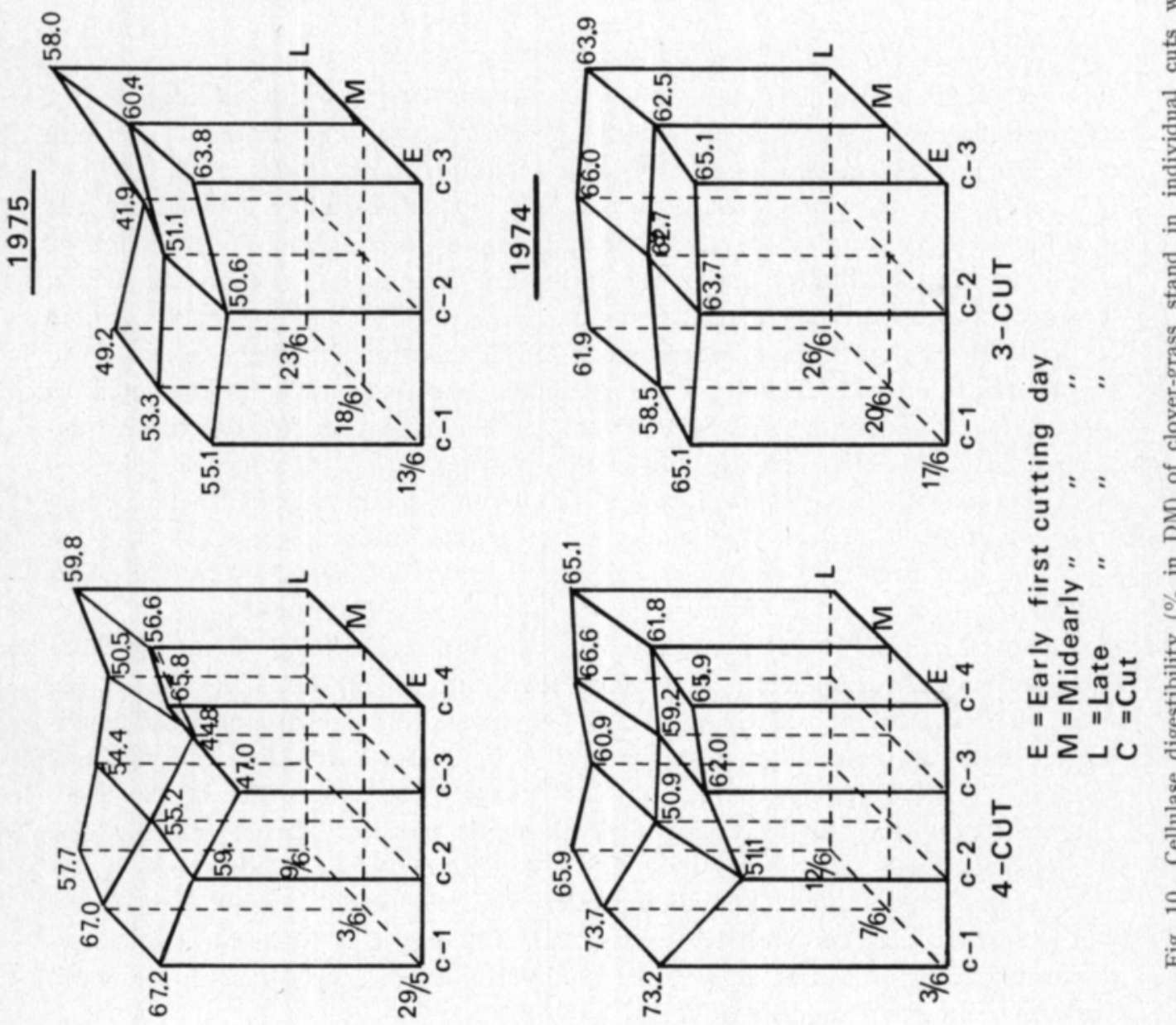

它: :

는

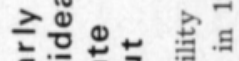

ส

| ||

$\Sigma$

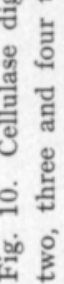



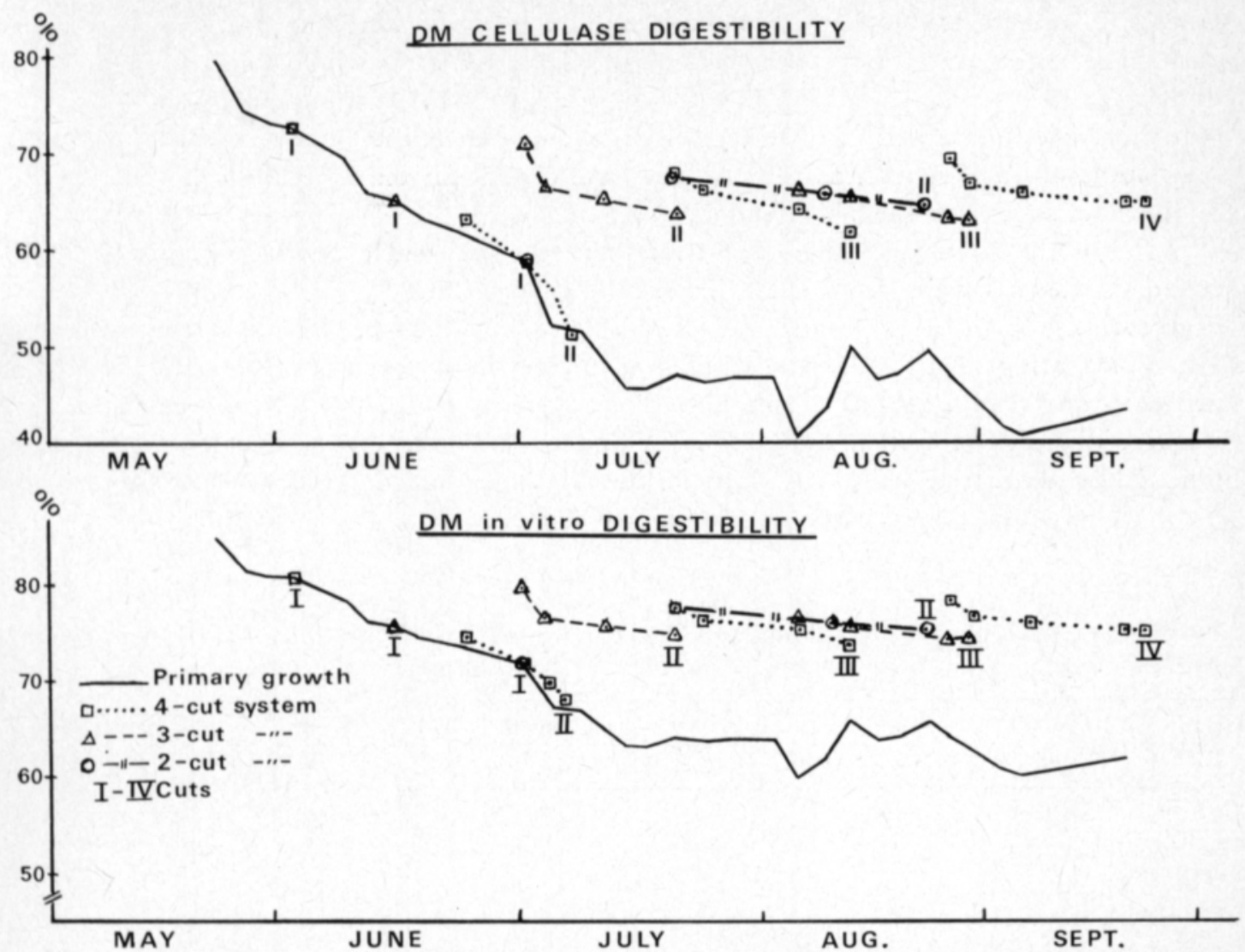

Fig. 11. Dry matter in vitro digestibility ( $\%$ in DM) and dry matter cellulase digestibility ( $\%$ in DM) development of clover-grass stand in primary growth and between individual cuts, harvested two, three and four times in 1974.

\section{Results}

The DM cellulase digestibility of the clover-grass stand was determined according to a chemical method developed by Jones and HAYWARD (1973). These values were adjusted to in vitro digestibility according to the model described by Pulli (1976). The dominant relationship between the cellulase (X) and in vitro (Y) digestibilities was the following linear equation:

$$
\mathrm{Y}=34.07+0.64 \mathrm{X} \quad\left(\mathrm{r}=0.99^{* * *}\right)
$$

The dry matter digestibility was measured weekly in 1974 and in all cuts during 1974-75. During the first spring cuts of 1974 June 3-12 and 1975 May 29 June 9 the dry matter cellulase digestibility decreased 0.81 and 0.86 $\%$-units a day respectively, which was equivalent to 0.51 and 0.64 in vitro percentage units a day (Fig. 10). During the periods June 17-26 1974 and June $13-231975$ the cellulase digestibility changes were 0.35 and $0.59 \%$-units a day respectively, or 0.22 and 0.37 in vitro \%-units (Fig. 10). The late first cuts made during July 1-9 1974 and June 27 - July 71975 had a decrease in cellulase digestibility of 0.92 and $0.25 \%$-units respectively or 0.58 and 0.16 
in vitro \%-units (Fig. 10). The changes in the cellulase and in vitro digestibilities during the second, third and fourth cuts of all cutting systems as well as in the primary growth of the stand are shown in Fig. 11. In both 1974 and 1975 the reduction in cellulase and in vitro digestibility had been relatively linear until the middle of July. After this the changes were dependent on the relationship of the new shoots to the old stand (Fig. 11).

In 1974 the average cellulase digestibility of the dry matter yields for all cutting systems ranged from 63.2 to $58.7 \%$ or $74.5-71.6 \%$ in vitro units (Table 15). For 1975 the range was $61.1-48.3 \%$ or $73.2-65.0 \%$ in vitro. When comparing 1974 to 1975 the differences in digestibility occurred primarily in the 2- and 3-cut systems (Table 15). The midearly cut of 1974 gave the weakest dry matter cellulase digestibility, and in 1975 the digestibility systematically decreased when the date of the first cut was delayed.

Table 15. Cellulase digestibility ( $\%$ in DM) of clover-grass stand with three different firstcutting dates, harvested two, three and four times per season in 1974-75.

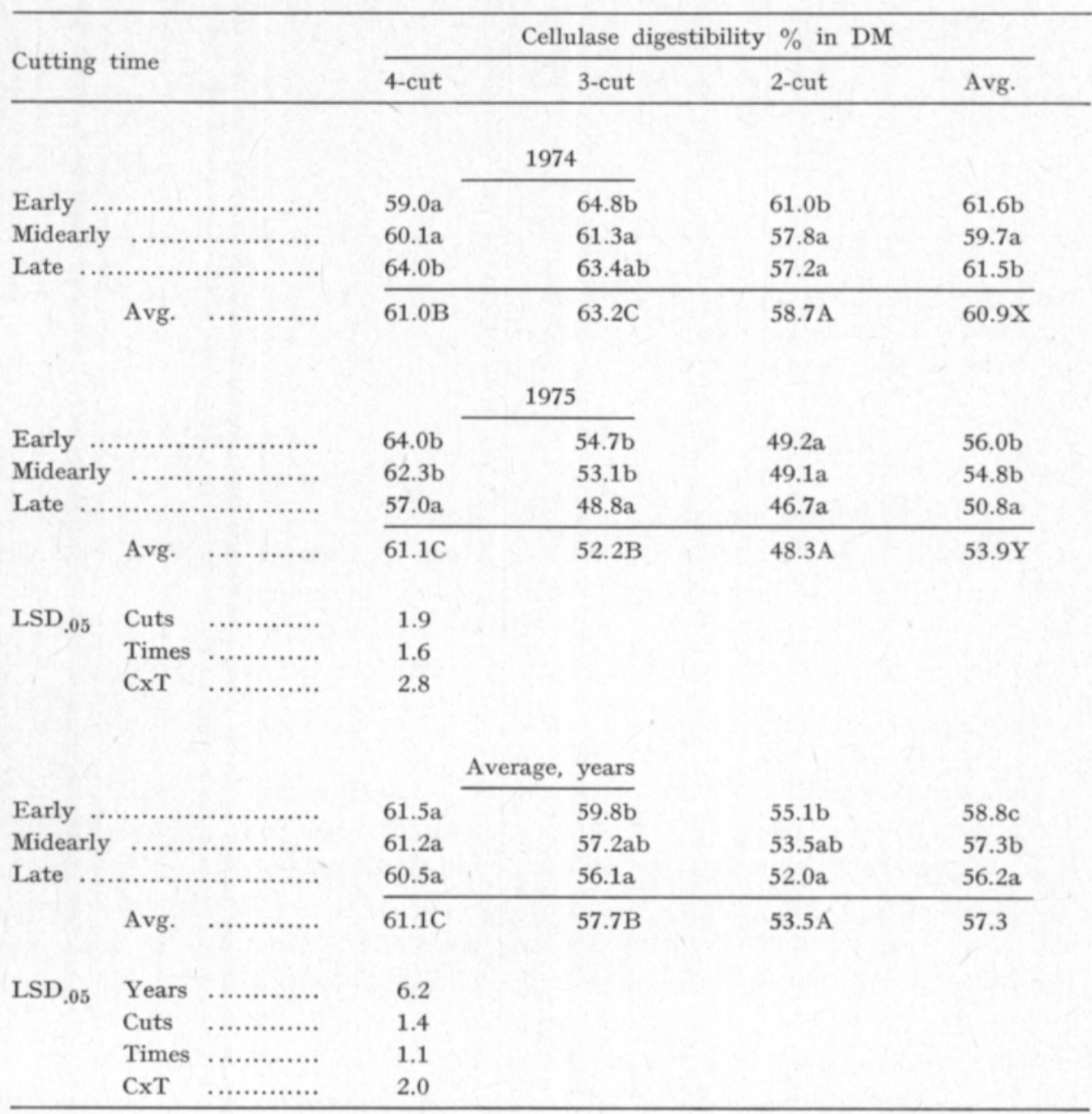


In this investigation relationships between individual growth factors and dry matter cellulase digestibility were looked for and an attempt was made to construct a regression model which best described the changes in digestibility which occurred in the different cuttings.

\section{Cut 1}

The changes in dry matter cellulase digestibility which occurred during the spring growth of a clover-grass stand were correlated strongest to the temperature sum. The changes were negatively correlated to all growth factors (Table 16). The highest coefficient of determination, $89.7 \%$, was obtained with the following regression model:

$$
\begin{array}{ll}
\mathrm{Y}=77.47-0.09471 \mathrm{X}_{1}+1.3169 \mathrm{X}_{2} \quad\left(\mathrm{~F}=67.2^{* * *}\right) \\
\text { where: } & \frac{\mathrm{R}^{2}}{25.3} \\
\mathrm{X}_{1}=\text { temperature sum in degree days }\left(\Sigma>0^{\circ} \mathrm{C}\right) & 85.3 \\
\mathrm{X}_{2}=\text { total radiation }\left(\Sigma \mathrm{Wh} \mathrm{cm}^{-2}\right) & 89.7
\end{array}
$$

Table 16. The correlation coefficients between growth factors and dry matter cellulase di-

\begin{tabular}{|c|c|c|c|c|c|}
\hline \multirow{2}{*}{\multicolumn{2}{|c|}{ Growth factors }} & \multicolumn{4}{|c|}{ Cuts } \\
\hline & & \multirow{2}{*}{$\begin{array}{c}1 s t \\
-.90^{* * *}\end{array}$} & \multirow{2}{*}{$\begin{array}{c}\text { 2nd } \\
-.17 \mathrm{NS}\end{array}$} & \multirow{2}{*}{$\frac{3 \mathrm{rd}}{.30 \mathrm{NS}}$} & \multirow{2}{*}{$\begin{array}{l}\text { 4th } \\
.16 \mathrm{NS}\end{array}$} \\
\hline$\Sigma$ days & (time) ... & & & & \\
\hline$\Sigma>0^{\circ} \mathrm{C}$ & (temp.) ........................... & $-.92^{* * *}$ & $-.23 \mathrm{NS}$ & $.09 \mathrm{NS}$ & $.21 \mathrm{NS}$ \\
\hline$\Sigma \mathrm{Wh} \mathrm{cm}^{-2}$ & 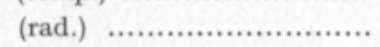 & $-.87 * * *$ & $-.32 \mathrm{NS}$ & $-.14 \mathrm{NS}$ & $.13 \mathrm{NS}$ \\
\hline$\Sigma \mathrm{mm}$ & (prec.) …........................ & $-.74 * * *$ & $.29 \mathrm{NS}$ & $.61 * *$ & $.13 \mathrm{NS}$ \\
\hline$\Sigma \mathrm{mm}$ & (prec. previous cut) ........ & & $.42^{*}$ & $.01 \mathrm{NS}$ & $-.13 \mathrm{NS}$ \\
\hline DM $\mathrm{kg} \mathrm{ha-1}$ & (previous cut) ..................... & & $.04 \mathrm{NS}$ & $.23 \mathrm{NS}$ & $.21 \mathrm{NS}$ \\
\hline
\end{tabular}
gestibility $(\%)$ in the first, second, third and fourth harvest of a clover-grass stand in $1974-76$.

In the regression model temperature had a decreasing effect on digestibility and radiation had an increasing effect.

\section{Cut 2}

The only statistically significant correlation in the second cut was between the digestibility and the yield of the previous cut. This means the higher the yield in the first cut the better the digestibility in the second cut which is connected to the low yield level and the early stage of development (Table 16). The following regression model with only precipitation factors described the cellulase digestibility of the second cut: where:

$$
\mathrm{Y}=50.49+0.2654 \mathrm{X}_{1}+0.0465 \mathrm{X}_{2} \quad\left(\mathrm{~F}=4.40^{*}\right)
$$

$$
\begin{array}{ll}
\mathrm{X}_{1}=\text { precipitation during a week before previous cut }(\Sigma \mathrm{mm}) & \frac{\mathrm{R}^{2}}{17.7} \\
\mathrm{X}_{2}=\text { precipitation between cuts }(\Sigma \mathrm{mm}) & 26.8
\end{array}
$$


For the third cut only the amount of precipitation for the cut had a statistically significant correlation to the DM cellulase digestibility. The following regression model best described the changes in digestibility:

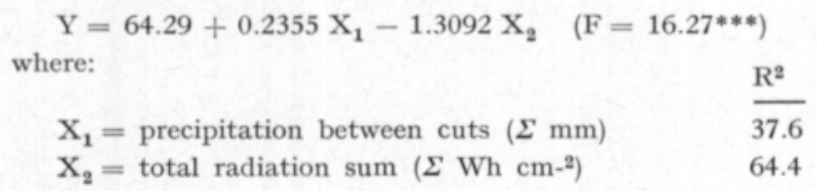

\section{Cut 4}

The cellulase digestibility of the autumn growth did not correlate significantly with any of the growth factors (Table 16). Also, no significant regression model was found in the selective regression analysis, but the $\mathrm{F}$ value was at the level of $\mathbf{8 5 . 5} \%$. The model used was:

$$
\mathrm{X}_{1}=\text { temperature sum in degree days }\left(\Sigma>0^{\circ} \mathrm{C}\right) \frac{\mathrm{R}^{2}}{45.5}
$$

\section{2. 5. Discussion}

Plant height development:

The rate of development of temperate climate long day plants is most dependent upon the temperature sum with the precondition that the soil moisture is enought to maintain the plant's turgidity (UTAAKER 1968). During the spring the height growth of the stand is the most influential factor on the yield (KELLY 1958). In this study the spring growth of a clover-grass stand correlated strongest with the spring's temperature sum and this is in agreement with OLofsson's (1962) study. In the selective regression analysis the spring temperature sum accounted for $95.2 \%$ of the spring height growth as shown also by HARI and LEIKOLA (1974).

The second and third cuts were made at a time where in six out of seven years in Southern Finland there is a period of over 20 days of sunny weather with no precipitation and a two week similar period every year (KORHONEN 1918). The amount of precipitation during the week before the previous cut is an important factor to the midsummer cut. This supports the statements of BRouWer (1959) and Johansson (1965) that a stand should be irrigated 1-3 weeks before cutting. According to KLAPP (1951) it is not beneficial to irrigate immediately after harvesting because the rate of evaporation is great and the total assimilating leaf surface is small. Mainly the amount of light and precipitation affect autumn height growth. High temperatures during the short autumn days mean respiration losses because light energy is usually the limiting factor. 
Dry matter content development:

The variation within a stand's dry matter content during the growing season was great as the variation between individual cuts, $15.5-30.6 \%$ in 1974 and, $22.9-51.8 \%$ in 1975 indicates. As the stand ages the dry matter content of the yield usually increases (Номв 1953, WinkLer et al. 1961). Nevertheless, in a young forage stand the dry matter content decreases until after the stem begins to grow (Kivimäe 1959). Salo et al. (1975) observed a decrease in the dry matter content of timothy and meadow fescue to the lowest levels of 13.4 and $16.8 \%$ respectively. The stand height at that time was about $60 \mathrm{~cm}$ for timothy and $35-50 \mathrm{~cm}$ for meadow fescue. In this study, because of the early stage of development, the stand's dry matter content decreased in the spring of 1974 by $1.53 \%$-units a day until June 12 , when the height was $46 \mathrm{~cm}$. After this the dry matter content of the spring growth rose an average of $0.38 \%$-units a day until July 9. During 1975 the stand was at an older stage than in 1974 and the dry matter content increase for the period May 29 - July 7 averaged. $0.44 \%$-units a day. At the same time the stand's height increased from 50 to $103 \mathrm{~cm}$. Under favorable growing conditions there is no difference between the total yield dry matter contents of the 3and 4-cut systems. Under dry conditions the dry matter content increases if the number of cuts is reduced or the first cut delayed. Also the midsummer dry periods raise the dry matter content of the yields as Sullivan et al. (1956) have shown. The dry matter content of the yield was most affected in the spring by temperature and precipitation, in the second cut by the radiation sum, temperature and precipitation, in the third cut by the physiological activity of the stand at the time of the previous cut, precipitation sum and temperature sum and in the autumn cut by the physiological activity of the stand at the time of the previous cut and the amount of precipitation for the previous cut.

Protein content development:

According to KIVIMÄE (1959) when the spring is warm and there is enough available water the stand's growth is rapid and the protein content decreases rapidly at first and then the rate of reduction slows. During a dry or cold spring stand growth is slow and protein content decreases as a linear function of time. In 1974 the drop in the raw protein content of a stand's spring growth at the pasture and silage stage was $0.6 \%$-units a day and at the hay stage $0.21 \%$-units a day. In 1975 the first cuts were made at the forage stage when the reduction in raw protein content of dry matter under the relatively cool conditions was $0.30 \%$-units a day, and at the hay stage $0.20 \%$-units daily. According to Mela (1974) the rate of reduction in a plant's protein content is especially affected by the available water. During a dry growing season a stand ages slowly and the reduction in raw protein content is slower than during a season having enough precipitation, even if the temperature is lower. This phenomenon appeared slightly in the midsummer cuts of 1974, but very strongly in the summer of 1975 when the changes in protein content were $0.10-0.16 \%$-units a day. 
The negative correlations between the 1974-75 dry matter yields and dry matter raw protein contents show that an increase in dry matter quantity means a loss in quality. By delaying the cut the amount of the yield of the first cut reflected the yield quality.

The protein content of the dry matter was most influenced in the spring by temperature sum, in the second cut by amount of precipitation, in the third cut by temperature and radiation sums and in the fourth cut by the temperature and radiation sums and the physiological state of the stand at the time of the previous cut.

\section{DM digestibility development:}

According to REID et al. (1959) at the same stage of development the digestibility of the spring growth is better than at later cuttings. REYNOLDS et al. (1969) found that the decrease in stand digestibility was greatest in a stand at a low level of nitrogen and cut frequently and least in a stand at a high nitrogen level and cut less frequently. In Viikki, because of exceptional growing conditions, the dry matter digestibility of a clover-grass stand differed from the pattern observed by REYNolds (1969) (Table 15).

Despite the different growing conditions between $1974-75$ the dry matter digestibility of the clover-grass stand in the individual cuts of each cutting system remained above $46 \%$, which is equal to an in vitro digestibility level of about $63.5 \%$. The differences between the digestibility of the yields of the individual cuts within the different cutting systems differentiated less between each other than those for protein content. It appears that the dry period of midsummer and the weak growth factors of late summer raise the protein content more than the digestibility of the dry matter. The differences do not appear to be because of the demands of different growth factors but because of changes in the plant's structure which during dry periods of the autumn are accompanied by increases in ligning and xylan (SALO et al. 1975). In the selective regression analysis the growth factors were nearly identical for the changes in protein content and digestibility.

\section{3. Protein production of a clover-grass stand}

\subsubsection{Growth factors and management techniques in relation to protein yield}

As the stand ages the dry matter yield increases at the same time as the raw protein content of the yield decreases. The increase in the raw protein yield slows even though the dry matter yield continues to increase strongly. According to KIVIMÄE (1965) the highest protein yield from timothy is obtained during the period between heading and the onset of flowering. SAU and VIIralt (1974) found the highest protein yield came from spring growth. Later changes in growth are slow and particularly in the autumn the raw protein yield remains small. Nitrogen fertilization raises the raw protein yield more than either the dry matter yield (KöYLIJÄRvi 1960) or the feed unit yield (SALONEN and Hirvola 1963). According to Teittinen (1958) $150 \mathrm{~kg} \mathrm{~N} \mathrm{ha}^{-1}$ can induce protein production in a grass stand equal to that of a clover-grass stand. STEEN 
(1972) found that grasses produced protein as much as legumes when cut three times and fertilized with $200-300 \mathrm{~kg} \mathrm{~N} \mathrm{ha}^{-1}$. Raininko (1968) found that red clover produced more raw protein than a grass stand, but less than a clovergrass stand when all stands received $200 \mathrm{~kg} \mathrm{~N} \mathrm{ha}^{-1}$. It was also shown that the positive influence of nitrogen on the raw protein yield and the utilization of nitrogen increased when switching to 3- and 4-cut systems from a 2-cut system. VALLE and VirTANEN (1932) obtained with a clover-timothy stand the highest raw protein yield of $1450 \mathrm{~kg} \mathrm{ha}^{-1}$ from the 2-cut system with the first cutting date on June 23. The second best yield of $1200 \mathrm{~kg} \mathrm{ha}^{-1}$ came from the 3-cut system with the first cutting date on June 3 and from the 2-cut system with the first cut made on July 1 . The protein yield of a red clover stand surpassed $2000 \mathrm{~kg} \mathrm{ha}^{-1}$ when cut twice with the first cut delayed until the beginning of July.

Results:

During 1974 the highest raw protein yield was obtained with the 4-cut system (Table 17). The yields of the 3 - and 2-cut systems were not statistically different from each other, but they were statistically and $300 \mathrm{~kg} \mathrm{ha}^{-1}$ less than the 4-cut yield. In 1975 the highest raw protein yield was produced by the 2-cut system, differing significantly from those of the 3- and 4-cut systems. Delaying the date of the first cut had no effect on the raw protein yield. The 1974 raw protein yield of $2123 \mathrm{~kg} \mathrm{ha}^{-1}$ differed significantly from the $938 \mathrm{~kg}$ $\mathrm{ha}^{-1}$ yield of 1975 .

Considering the protein yield an attempt was also made to determine any relationships between growth factors and yield variations. The research method was based on correlations between individual growth factors and yield level and selective regression analysis.

\section{Cut 1}

The spring temperature sum had the strongest correlation to the changes in the protein yield of the first cut (Table 18). The highest coefficient of determination, $95.2 \%$, was obtained with the following regression model:

$$
\begin{array}{lc}
\mathrm{Y}=145.9+2.29 \mathrm{X}_{1}+8.094 \mathrm{X}_{2}-43.47 \mathrm{X}_{3} & \left(\mathrm{~F}=92.23^{* * *}\right) \\
\text { where: } & \frac{\mathrm{R}^{2}}{81.7} \\
\mathrm{X}_{1}=\text { temperature sum in degree days }\left(\Sigma>0^{\circ} \mathrm{C}\right) & 87.4 \\
\mathrm{X}_{2}=\text { precipitation }(\Sigma \mathrm{mm}) & 95.2 \\
\mathrm{X}_{3}=\text { total radiation sum }\left(\Sigma \mathrm{Wh} \mathrm{cm}^{-2}\right) &
\end{array}
$$

\section{Cut 2}

The precipitation during the week before the previous cut had a strong positive correlation to the development of the raw protein yield (Table 18). The radiation sum and growing time had the significant negative correlations. The increase of these growth factors with a lack of water means a decrease in the protein yield. The regression model obtained was as follows: 
Table 17. Protein yields $\mathrm{kg} \mathrm{ha}^{-1}$ of grass-clover stand with three different first cutting dates harvested two, three and four times per season in 1974-75.

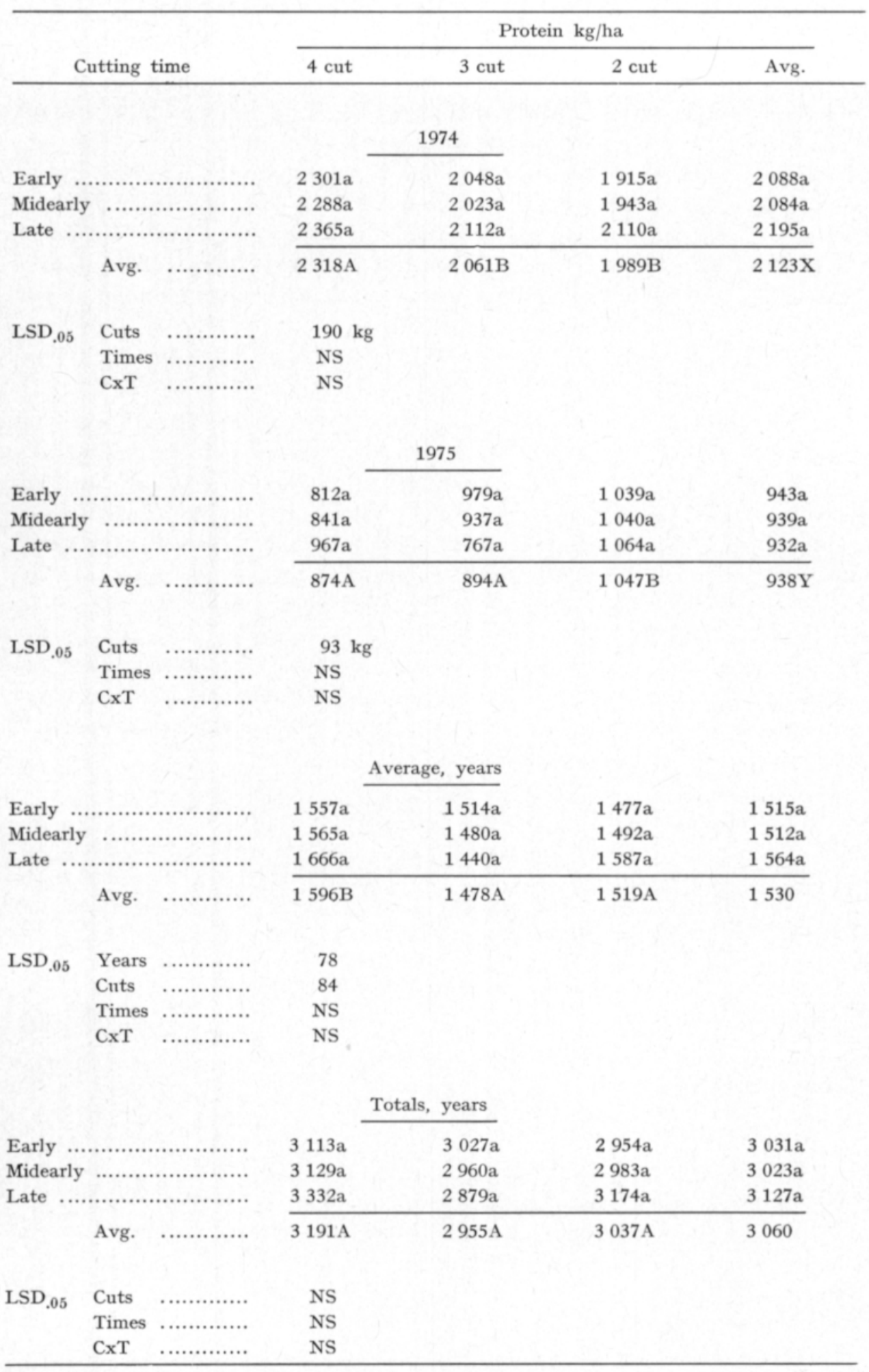


Table 18. The correlation coefficients between growth factors and protein yield $\mathrm{kg} \mathrm{ha}^{-1}$ in the first, second, third and fourth harvest of a clover-grass stand in 1974-76.

\begin{tabular}{|c|c|c|c|c|c|}
\hline \multirow{2}{*}{\multicolumn{2}{|c|}{ Growth factors }} & \multicolumn{4}{|c|}{ Cuts } \\
\hline & & \multirow{2}{*}{$\begin{array}{l}1 \text { st } \\
88^{* * * *}\end{array}$} & \multirow{2}{*}{$\begin{array}{l}\text { 2nd } \\
-.44^{*}\end{array}$} & \multirow{2}{*}{$\begin{array}{c}3 \mathrm{rd} \\
-.67^{* * * *}\end{array}$} & \multirow{2}{*}{$\begin{array}{l}\text { 4th } \\
-.23 \mathrm{NS}\end{array}$} \\
\hline$\Sigma$ days & (time) $\ldots . .$. & & & & \\
\hline$\Sigma>0^{\circ} \mathrm{C}$ & (temp.) ....................... & $90^{* * *}$ & $-.49 * *$ & $-.78 * * *$ & $.46 \mathrm{NS}$ \\
\hline 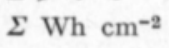 & 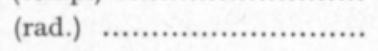 & $85^{* * *}$ & $-.61 * * *$ & $-.77^{* * *}$ & $.64^{*}$ \\
\hline$\Sigma \mathrm{mm}$ & 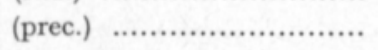 & $88^{* * *}$ & $.31 \mathrm{NS}$ & $-.23 \mathrm{NS}$ & $.78 * *$ \\
\hline$\Sigma \mathrm{mm}$ & (prec. previous cut) ....... & & $.78^{* * *}$ & $.86^{* * *}$ & $.25 \mathrm{NS}$ \\
\hline DM kg ha-1 & 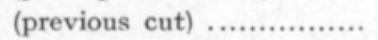 & & $-.29 \mathrm{NS}$ & $.54^{*}$ & $.89 * * *$ \\
\hline
\end{tabular}

$$
\mathrm{Y}=273.6+6.35 \mathrm{X}_{1}+38.72 \mathrm{X}_{2}+15.34 \mathrm{X}_{3}-36.36 \mathrm{X}_{4} \quad\left(\mathrm{~F}=65.46^{* * *}\right)
$$
where:

$$
\begin{array}{ll}
\mathrm{X}_{1}=\text { precipitation during a week before previous cut }(\Sigma \mathrm{mm}) & \frac{\mathrm{R}^{2}}{60.6} \\
\left.\mathrm{X}_{2}=\text { total radiation sum }(\Sigma \mathrm{Wh} \mathrm{cm})^{-2}\right) & 76.3 \\
\mathrm{X}_{3}=\text { precipitation between cuts }(\Sigma \mathrm{mm}) & 83.2 \\
\mathrm{X}_{4}=\text { growing time }(\Sigma \text { days }) & 92.0
\end{array}
$$

\section{Cut 3}

The precipitation during the week before the previous cut and the physiological state of the stand at the time of the previous cut were the two growth factors which correlated positively to protein yield of the third cut (Table 18). Temperature sum, radiation sum and growing time all had negative correlations. The regression model was:

$$
\mathrm{Y}=-473.1+31.07 \mathrm{X}_{1}+4.55 \mathrm{X}_{2} \quad\left(\mathrm{~F}=46.55^{* * *}\right)
$$
where:

$$
\begin{array}{ll}
\mathrm{X}_{1}=\text { precipitation during a week before previous cut }(\Sigma \mathrm{mm}) & \frac{\mathrm{R}^{2}}{74.7} \\
\mathrm{X}_{2}=\text { precipitation between cuts }(\Sigma \mathrm{mm}) & 83.8
\end{array}
$$

\section{Cut 4}

The physiological activity of the stand at the time of the third cut was the most important factor in the formation of the late autumn protein yield. Also the amount of precipitation and radiation sum had positive correlations (Table 18). The four variables presented in the following regression model accounted for $100 \%$ the variation in the late autumn protein yield:

$$
\begin{array}{lr}
\mathrm{Y}=32.1+0.12 \mathrm{X}_{1}+1.19 \mathrm{X}_{2}+95.05 \mathrm{X}_{3}-1.97 \mathrm{X}_{4} \quad(\mathrm{~F}=702.06 * *) \\
\text { where: } \\
\begin{array}{lr}
\mathrm{X}_{1}=\text { DM yield in previous cut }\left(\mathrm{kg} \mathrm{ha}^{-1}\right) & \frac{\mathrm{R}^{2}}{9.2} \\
\mathrm{X}_{2}=\text { precipitation during a week before previous cut }(\Sigma \mathrm{mm}) & 96.8 \\
\mathrm{X}_{3}=\text { total radiation sum }\left(\Sigma \mathrm{Wh} \mathrm{cm}^{-2}\right) & 98.5 \\
\mathrm{X}_{4}=\text { temperature sum in degree days }\left(\Sigma^{\prime}>0^{\circ} \mathrm{C}\right) & 100.0
\end{array}
\end{array}
$$




\section{3. 2. Discussion}

Temperature sum during the spring growth has been the most influential factor on dry matter yield and protein content changes and on the formation of the protein yield per surface area unit. In the regression analyses temperature has also been the most important variable in describing spring protein yield. In the second cut the dry matter yield correlated strongest to the amount of precipitation during the week before the first cut. The protein content correlated strongest to the precipitation between the first and second cuts. However, because the protein yield of the second cut was most influenced by the dry matter yield, it follows that also the changes in the protein yield were strongly correlated to the amount of precipitation during the week before the previous cut. In the selective regression analysis the most important and descriptive factor of the second cut's dry matter yield, raw protein content and protein yield has been the amount of precipitation the week before the first cut. Also the second and third most important factors, the amount of radiation per cut and precipitation between cuts, are common to all of the descriptive yield components.

Also in the third cut the amount of precipitation during the week before the previous cut was the most important factor for the dry matter yield, protein content of DM and raw protein yield. However, in the regression analyses water has been the important factor only for the dry matter and raw protein yields. For the protein content in DM it has been temperature, which raises the protein content of a plant by causing apical dormancy and indirectly inducing the growth of auxiliary shoots.

For the fourth cuts, which were made during August 12 - October 10, the strongest individual growth factor was the yield of the third cut, which described the stand's physiological activity and release from dormancy. In the regression analyses the third cut's yield was the most important factor for the dry matter yield. For the raw protein content the amount of light was the most important factor. Lack of light slows the reduction of protein content whereas sufficient light encourages plant development and rapidly reduces the protein content. The most important variable in the regression model of the raw protein yield was the stand's physiological state at the time of the previous cut. For both the dry matter and raw protein yields water was the second most important factor in the regression model. It is therefore obvious that reduced light but sufficient temperature much water is needed for the uptake of nutrients as the plant changes its physiology towards wintering.

The aforementioned correlations and regression models support the opinions of Olofsson (1962) and HARI and LeIKola (1974) that temperature is a significant factor in spring growth under Finnish conditions. They also support the research results of Korhonen (1940), PaAtela and Suomela (1962) and Hooli (1971) that during summer growth stands in Southern Finland suffer periods of severe dryness during which evapotranspiration and the need for water is great. The autumn growth of a plant is vegetative. RAPPE (1948) has shown that the reduction in growth is a result of changes in hormone activity under changing autumn growing conditions. 


\section{4. Plant species relationships of a clover-grass stand}

\section{4.1. Dry matter production of the species}

In the plant community the degree of the competition directed toward an individual plant depends upon a) the growing density and the proportion of different plant species b) plant species and, c) the duration of the competition (Bleasdale 1960, Donald 1963, Baeumer 1964). Jones (1936) listed the following factors which affect plant competition; short plants suffer lack of light in the presence of tall plants; slowly developing plants suffer from the growth rhythm of fast developing plants; the amount and speed of regrowth is affected by the plants with a different agressiveness, a quality which allows a species to grow faster than another or by influencing another species simply by its presence.

All grass species benefit by growing with clover. According to HoLmes and MAC LUSKY (1955) meadow fescue benefits most, timothy less and orchard grass the least. Several investigations (ÅBERg et al. 1943, CAPUta 1948, Jäntti 1953, Giöbel and Steen 1961 and Raininko 1968) have shown that timothy coexists poorly with meadow fescue and even worse with orchard grass.

Nitrogen increases the presence of grass in a stand whereas P- and PKfertilizer and $\mathrm{Ca}$ increase the portion of clover (JÄÄSKELÄINEN 1929). The reducing effect of nitrogen on clover is due to that grass species utilize $\mathrm{N}$ more efficiently than clover and thereby have better competitive ability. As a result clover suffers from lack of light (Frank 1952, SALONEN 1959).

The rhythm of development influences the ability of plants to withstand drought and the competition between plants. At the shooting stage clover has the strongest root system, meadow fescue slightly weaker and orchard grass and timothy the weakest (PohJakallio 1948). The development of the root system influences most strongly the composition of plant species in a first year stand. Also resistance to drought influences the composition. Orchard grass revives best from the drought when it rains. Meadow fescue is slightly slower and red clover and timothy are the slowest (LinJA-AHO 1952).

The utilization of the forage influences the plant species composition and productivity of the stand. KLAPP (1937) listed the grasses grazing abilities according to the length of use: Kentucky blue grass, red fescue, meadow fescue, orchard grass and timothy. According to Lehtisalo (1956) red clover survives best in a stand that is cut rather than grazed. RAINinko (1968) found that increasing the number of cuts reduced the dry matter yield most in a grass stand, less in a clover-grass stand and least in a red clover stand.

Results:

The clover-grass stand was seeded with a companion crop in the spring of 1973. The stand mixture comprised timothy $6 \mathrm{~kg}(20 \%)$, red clover $6 \mathrm{~kg}$ $(20 \%)$ and meadow fescue $18 \mathrm{~kg}(60 \%)$. In the first cut in 1974 timothy had increased its percentage in the spring growth from 23.0 to $34.3 \%$ during the period June $3-26$ and then decreased to $17.5 \%$ by July 9 (Table 19). In the late stages of spring growth timothy was replaced mostly by red clover which increased from $23.4 \%$ to $55.8 \%$ of the spring yields. Meadow fescue remained very stable at an average of $24.0 \%$. 
Table 19. Species $\%$ of timothy, meadow fescue and red clover in clover-grass stand harvested two, three and four times with three first cutting days in 1974 and post effects in the first harvest of 1975.

\begin{tabular}{|c|c|c|c|c|c|c|c|c|c|}
\hline \multirow{2}{*}{$\begin{array}{l}\text { Cutting } \\
\text { system }\end{array}$} & \multirow[b]{2}{*}{ Time } & \multicolumn{4}{|c|}{ Species $\%$ in mixture 1974} & \multicolumn{2}{|c|}{ Average } & \multirow{2}{*}{$\begin{array}{l}\text { Post } \\
\text { effect }\end{array}$} & \multirow[b]{2}{*}{1975} \\
\hline & & Cut 1 & Cut 2 & Cut 3 & Cut 4 & $\overline{\mathbf{x}}$ & $\overline{\bar{x}}$ & & \\
\hline & & & & & mothy & & & & \\
\hline \multirow{3}{*}{ 4-cut } & E & 23.0 & 34.5 & 13.9 & 8.7 & 20.0 & & 33.0 & \\
\hline & M & 28.5 & 31.9 & 14.7 & 11.7 & 21.7 & 19.9 & 51.1 & 45.2 \\
\hline & $\mathbf{L}$ & 32.3 & 14.1 & 10.0 & 15.0 & 17.9 & & 51.5 & \\
\hline \multirow[t]{3}{*}{ 3-cut } & $\mathrm{E}$ & 33.7 & 14.9 & 16.6 & & 21.7 & & 46.0 & \\
\hline & M & 33.9 & 12.7 & 11.4 & & 19.3 & 21.8 & 26.6 & 38.1 \\
\hline & L & 34.3 & 16.6 & 22.6 & & 24.5 & & 41.8 & \\
\hline \multirow[t]{4}{*}{ 2-cut } & E & 22.5 & 18.6 & & & 20.6 & & 33.3 & \\
\hline & M & 22.9 & 16.0 & & & 19.5 & 18.7 & 34.3 & 29.6 \\
\hline & L & 17.5 & 14.6 & & & 16.1 & & 21.3 & \\
\hline & Avg. & 27.7 & 19.3 & 14.9 & 11.8 & 20.1 & & 37.7 & \\
\hline
\end{tabular}

\begin{tabular}{|c|c|c|c|c|c|c|c|c|c|}
\hline \multirow[b]{2}{*}{ 4-cut } & \multirow[b]{2}{*}{$\mathrm{E}$} & \multirow[b]{2}{*}{25.9} & \multirow[b]{2}{*}{23.6} & \multicolumn{2}{|c|}{ Meadow fescue } & \multirow[b]{2}{*}{37.8} & & \multirow[b]{2}{*}{41.9} & \multirow[b]{3}{*}{36.4} \\
\hline & & & & 40.4 & 61.1 & & & & \\
\hline & M & 27.3 & 26.4 & 47.4 & 56.3 & 39.4 & 40.1 & 35.0 & \\
\hline & L & 26.2 & 42.9 & 40.5 & 62.8 & 43.1 & & 32.3 & \\
\hline \multirow[t]{3}{*}{ 3-cut } & E & 22.6 & 24.6 & 37.1 & & 28.1 & & 34.2 & \\
\hline & M & 20.4 & 29.2 & 51.8 & & 33.8 & 32.3 & 51.9 & 42.7 \\
\hline & $\mathbf{L}$ & 19.7 & 45.1 & 40.3 & & 35.0 & & 42.1 & \\
\hline \multirow[t]{4}{*}{ 2-cut } & $\mathrm{E}$ & 25.4 & 34.8 & & & 30.1 & & 43.1 & \\
\hline & M & 28.0 & 38.4 & & & 33.2 & 32.2 & 36.9 & 42.6 \\
\hline & L & 20.5 & 46.2 & & & 33.4 & & 47.8 & \\
\hline & Avg. & 24.0 & 34.6 & 42.9 & 60.1 & 34.9 & & 40.6 & \\
\hline
\end{tabular}

\begin{tabular}{|c|c|c|c|c|c|c|c|c|c|}
\hline \multirow[b]{2}{*}{ 4-cut } & \multirow[b]{2}{*}{ E } & \multicolumn{4}{|c|}{ Red clover } & \multirow[b]{2}{*}{19.2} & & \multirow[b]{2}{*}{3.0} & \multirow[b]{3}{*}{4.} \\
\hline & & 23.4 & 19.4 & 20.9 & 13.2 & & & & \\
\hline & M & 23.4 & 29.6 & 24.7 & 24.8 & 25.6 & 23.5 & 4.3 & \\
\hline & $\mathrm{L}$ & 31.5 & 23.6 & 35.1 & 12.8 & 25.8 & & 4.8 & \\
\hline \multirow[t]{3}{*}{ 3-cut } & E & 28.1 & 43.4 & 34.4 & & 35.3 & & 10.5 & \\
\hline & M & 25.9 & 37.0 & 19.4 & & 27.4 & 29.3 & 1.0 & 6.7 \\
\hline & L & 25.7 & 25.9 & 24.1 & & 25.2 & & 8.7 & \\
\hline \multirow[t]{4}{*}{ 2-cut } & $\mathrm{E}$ & 31.9 & 34.5 & & & 33.2 & & 7.0 & \\
\hline & M & 31.7 & 18.1 & & & 24.9 & 33.9 & 11.5 & 7.4 \\
\hline & L & 55.8 & 31.0 & & & 43.4 & & 3.6 & \\
\hline & Avg. & 30.8 & 29.2 & 26.4 & 16.9 & 28.9 & & 6.0 & \\
\hline
\end{tabular}

LSD $_{.05}$ Varieties 3.7

Cuts NS

(1974) Dates NS 
The second cut (Table 19) showed quite clearly that timothy's growth occurs in the early summer and its regrowth ability decreases significantly after the beginning of July. The early second cut of the 4-cut system had the highest timothy percentage of $34.5 \%$ and the lowest of $14.6 \%$ was in the late cut. The reduction in timothy was compensated for by the good regrowth of meadow fescue. Its percentage of the yield rose from $23.6 \%$ in the early second cut of the 4-cut system to $46.2 \%$ by the time of the late second cut in the 2-cut system. The good regrowth ability of red clover and its balanced distribution through the growing season was clearly shown in all second cuts for all cutting systems.

The most important observations in the third cut were the low regrowth of timothy, the increase of meadow fescue in the yield to an average of $42.9 \%$ (Table 19) and red clover's good regrowth and balanced distribution. The average amount of red clover in the third cut was $26.4 \%$.

In the fourth cut, after the autumn growth (Table 19), only the meadow fescue had retained its productivity. The percentages of timothy, red clover and meadow fescue in the yield of the fourth cut were $11.8 \%, 16.9 \%$ and $60.1 \%$ respectively.

Delaying the first cut had very little effect on the yield distributions of the plants, except in the 2-cut system, where the delay increased the percentage of red clover significantly.

The dry matter yields of the different plant species in a clover-grass stand show (Fig. 12) that all species had the highest yields in the second cut of the 4-cut system. In the 3-cut system timothy and red clover produced the highest yields in the first cut and meadow fescue in the third cut. For the 2-cut system the yields of timothy and red clover were highest in the spring cut while meadow fescue had close to identical yields in both cuts. Couch grass had some significance only in the first cut of the 2-cut system.

4-CUT

DM

tons ha-1
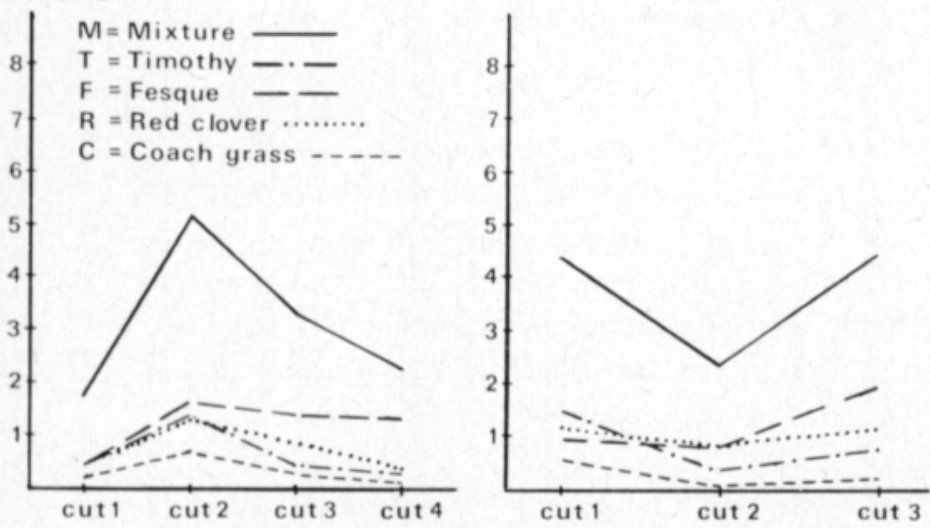

$\underline{2-C U T}$

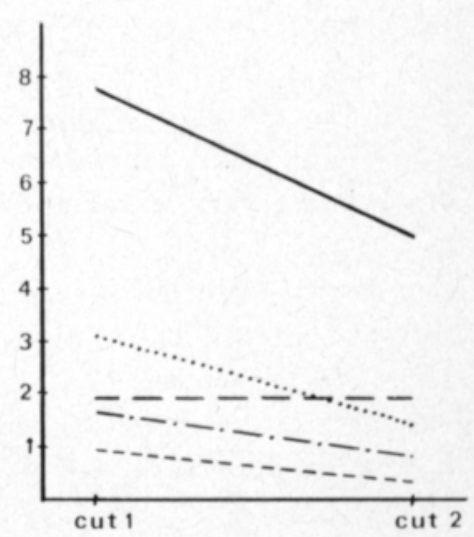

Fig. 12. Dry matter yields (tons $h^{-1}$ ) of clover-grass stand and different plant species of the mixture in individual cuts, harvested two, three and four times in 1974. 
The post effects of the 1974 treatments were investigated in the first cut of 1975 , where all plots were cut at the same time. The highest cutting frequency (4-cut) had not damaged the timothy and meadow fescue stands. Also the good spring growth of timothy was observed, paricularly in the 4-cut system were the high cutting frequency stimulated good shooting ability in the stand. The relatively intensive fertilization program of $270 \mathrm{~kg} \mathrm{~N} \mathrm{ha}^{-1}$ increased the competitive ability of the grasses as compared to red clover. This can be seen in the rather modest share of red clover in the second year's spring growth.

\section{4.2. Quality characteristics of species}

Changes in the plant species composition often result in changes in the protein content of the forage stand. RAININKo (1968) found that whether in pure or mixed stands the protein content of red clover remained comparatively stable despite $\mathrm{N}$-fertilization and irrigation. The protein content of grasses was higher with red clover than in pure stands or in grass mixtures.

The digestibility of a forage stand decreases as the plants age. The influence of the stage of development on the digestibility depends partly on the earliness of a plant species or plant variety. At the same stage of development the digestibility is usually better in an early type grass than in a late type (PRITCHARD et al. 1963, Christie and Mowat 1968). On the other hand, the digestibility of a late type plant species such as red clover remains good longer (Minson et al. 1960 a, 1964, RAYMond 1969). According to Hakkola (1978) English rye grass had the highest and orchard grass the lowest digestibility at all stages of development. Timothy and meadow fescue came between these two.

\section{Results:}

On June 31974 in the first cut of the 4-cut system the protein contents in the DM of the three species, timothy, meadow fescue and red clover, were the same, 27.1-27.4\% (Table 20). The reduction in the protein contents of the three species during June 3 - July 9 were timothy $16.5 \%$-units, meadow fescue $16.0 \%$-units and red clover $12.0 \%$-units or $0.45,0.44$ and $0.33 \%$ units daily. The protein content of timothy in the second, third and fourth cuts was sligthly lower than for meadow fescue.

In the autumn cuttings the protein contents of red clover had increased more than those of the grasses (Table 20). The average raw protein contents of timothy, meadow fescue and red clover in the 4-cut system were 19.0, 19.8 and $23.1 \%$ respectively. In the 3 -cut system the corresponding values were 18.1 , 19.0 and $21.6 \%$, and in the 2-cut system $15.1,16.1$ and $18.8 \%$. The average protein contents of timothy, meadow fescue and red clover under all management practices were $17.4 \%, 18.3$ and $21.1 \%$ respectively. The raw protein contents of red clover and couch grass were the highest in all cuts of the 2-, 3- and 4-cut systems (Fig. 13).

On June 3 the cellulase digestibilities of the stand's species were timothy $72.6 \%$, meadow fescue $74.2 \%$ and red clover $63.7 \%$. The corresponding values 36 days later on the final cut of the spring were $44.1 \%, 44.5 \%$ and 
Table 20. Protein content of timothy, meadow fescue and red clover in clover-grass stand in invididual cuts harvested two, three and four times with three first cutting dates in 1974 .

\begin{tabular}{|c|c|c|c|c|c|c|c|}
\hline \multirow{2}{*}{$\begin{array}{l}\text { Cutting } \\
\text { system }\end{array}$} & \multirow[b]{2}{*}{ Time } & \multicolumn{4}{|c|}{ Protein $\%$ in DM } & \multirow{2}{*}{$\begin{array}{l}\text { Average } \\
\bar{x}\end{array}$} & \multirow[b]{2}{*}{$\overline{\bar{x}}$} \\
\hline & & Cut 1 & Cut 2 & Cut 3 & Cut 4 & & \\
\hline & & & & Timothy & & & \\
\hline \multirow[t]{3}{*}{ 4-cut } & $\mathrm{E}$ & 27.4 & 11.0 & 18.7 & 19.6 & 19.2 & \\
\hline & M & 23.8 & 12.1 & 18.7 & 20.1 & 18.7 & 19.0 \\
\hline & L & 20.7 & 16.0 & 17.7 & 22.5 & 19.2 & \\
\hline \multirow[t]{3}{*}{ 3-cut } & E & 16.2 & 21.9 & 17.7 & & 18.6 & \\
\hline & M & 15.9 & 20.6 & 18.0 & & 18.2 & 18.1 \\
\hline & L & 12.1 & 20.6 & 19.9 & & 17.5 & \\
\hline \multirow[t]{4}{*}{ 2-cut } & E & 13.2 & 19.3 & & & 16.3 & \\
\hline & M & 11.8 & 17.9 & & & 14.9 & 15.1 \\
\hline & L & 10.9 & 17.3 & & & 14.1 & \\
\hline & Avg. & 16.9 & 17.4 & 18.5 & 20.7 & 17.4 & \\
\hline \multicolumn{8}{|c|}{ Meadow fescue } \\
\hline \multirow[t]{3}{*}{ 4-cut } & $\mathrm{E}$ & 27.1 & 13.1 & 18.9 & 17.9 & 19.3 & \\
\hline & M & 24.2 & 13.3 & 19.8 & 21.2 & 19.6 & 19.8 \\
\hline & L & 21.0 & 18.6 & 18.0 & 23.9 & 20.4 & \\
\hline \multirow[t]{3}{*}{ 3-cut } & E & 16.6 & 23.0 & 19.0 & & 19.5 & \\
\hline & M & 16.5 & 21.5 & 20.2 & & 19.4 & 19.0 \\
\hline & L & 11.8 & 21.1 & 21.3 & & 18.1 & \\
\hline \multirow[t]{5}{*}{ 2-cut } & $\mathrm{E}$ & 12.2 & 21.6 & & & 16.9 & \\
\hline & M & 11.4 & 20.7 & & & 16.1 & 16.1 \\
\hline & $\mathrm{L}$ & 11.1 & 19.5 & & & 15.3 & \\
\hline & Avg. & 16.9 & 19.2 & 19.5 & 21.0 & 18.3 & \\
\hline & & & & Red clove & & & \\
\hline \multirow[t]{3}{*}{ 4-cut } & $\mathrm{E}$ & 27.2 & 16.9 & 23.4 & 23.8 & 22.8 & \\
\hline & M & 26.4 & 16.6 & 23.1 & 25.2 & 22.8 & 23.1 \\
\hline & L & 24.9 & 21.2 & 21.5 & 27.0 & 23.7 & \\
\hline \multirow[t]{3}{*}{ 3-cut } & E & 22.1 & 23.2 & 22.1 & & 22.5 & \\
\hline & M & 20.3 & 23.0 & 21.2 & & 21.5 & 21.6 \\
\hline & L & 17.8 & 23.0 & 21.2 & & 20.7 & \\
\hline \multirow[t]{4}{*}{ 2-cut } & $\mathrm{E}$ & 16.6 & 22.2 & & & 19.4 & \\
\hline & M & 15.4 & 21.3 & & & 18.4 & 18.8 \\
\hline & L & 15.2 & 21.8 & & & 18.5 & \\
\hline & Avg. & 20.7 & 21.0 & 22.1 & 25.3 & 21.1 & \\
\hline
\end{tabular}

LSD $_{.05}$ Varieties 1.1

Cuts $\quad 6.6$

Dates $\quad 6.6$ 

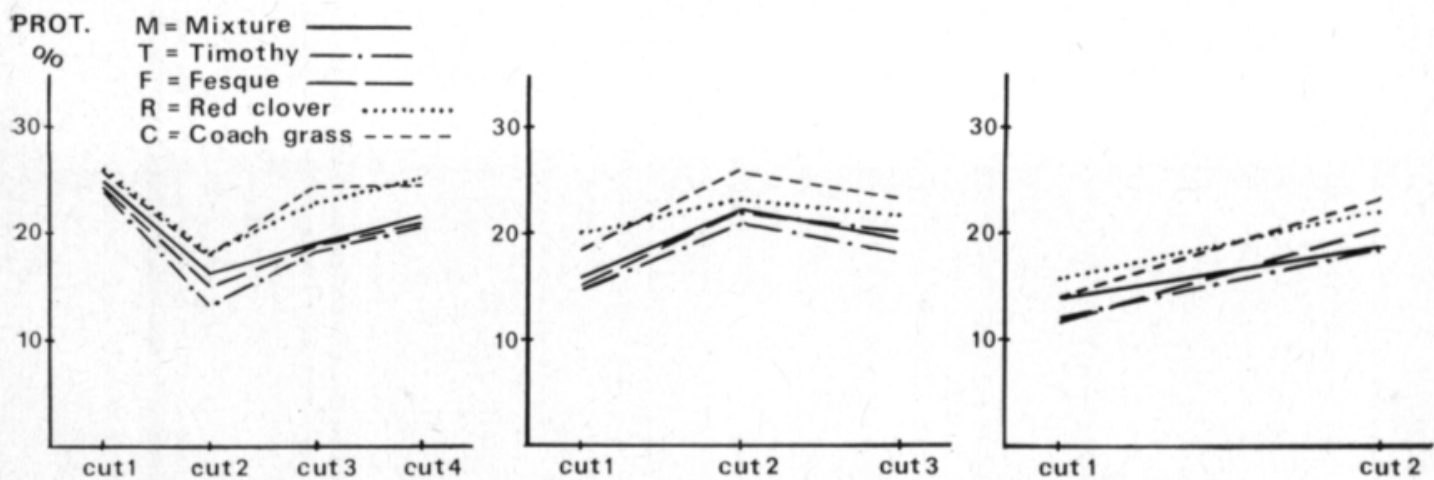

Fig. 13. Protein content of dry matter ( $\%$ in DM) of clover-grass stand and different plant species of the mixture in individual cuts harvested two, three and four times in 1974.

$56.4 \%$ (Table 21). On June 3 the cellulase digestibility of red clover was 8.9 and $10.5 \%$-units less than timothy and meadow fescue respectively but on July 9 it was 12.3 and $11.9 \%$-units more than the same respective species. In the mixed stand the daily reduction in cellulase digestibility during spring growth for timothy, meadow fescue and red clover was $0.79,0.82$ and 0.20 $\%$-units which were equivalent to $0.50,0.52$ and 0.12 in vitro $\%$-units a day. These values show that the changes in the digestibility of timothy and meadow fescue are strong, and those for red clover are slower.

The second cut (Table 21) of the 4-cut system displays high yield potential where the percentage of timothy in the yield is great (Table 19). For this particular reason the digestibility of timothy in the second cut of the 4-cut system was less than that of meadow fescue and even lower than that of red clover. The favorable growing conditions of the summer of 1974 evened the digestibility of the different species in the second cuts of the 2- and 3-cut systems.

In the mid- and late summer third cuts of the 3- and 4-cut systems meadow fescue had the highest digestibility followed by timothy and then red clover. The same order repeated itself also in the fourth cut made in late autumn.

Delaying the date of the first cut reduced the digestibility of timothy an average of $1.5 \%$-units, $2.2 \%$-units and $5.5 \%$-units in the 4 -, 3- and 2-cut systems respectively. The delay had the same effect on red clover and the corresponding values were 2.5, 5.4 and $3.3 \%$-units. For meadow fescue delaying the first cut raised the average cellulase digestibility for the growing season by $2.6 \%$-units in the 4 -cut system and decreased it by $5.1 \%$-units in the 2-cut system whereas the middle cutting date in the 3-cut system was the most favorable for digestibility (Table 21). Increasing the cutting frequency raised the dry matter cellulase digestibility of the grasses but lowered it for red clover as can be seen by red clover's slower growth rhythm and good quality and quality competitive ability in the stand for dry hays. 
Table 21. Cellulase digestibility \% in DM of timothy, meadow fescue and red clover in clovergrass stand in individual cuts harvested two, three and four times with three first cutting dates in 1974 .

\begin{tabular}{|c|c|c|c|c|c|c|}
\hline \multirow{2}{*}{$\begin{array}{l}\text { Cutting } \\
\text { system }\end{array}$} & \multirow[b]{2}{*}{ Time } & \multicolumn{4}{|c|}{ Cellulase dig. $\%$ in DM } & \multirow{2}{*}{${ }_{-}^{\text {Average }}$} \\
\hline & & Cut 1 & Cut 2 & Cut 3 & Cut 4 & \\
\hline
\end{tabular}

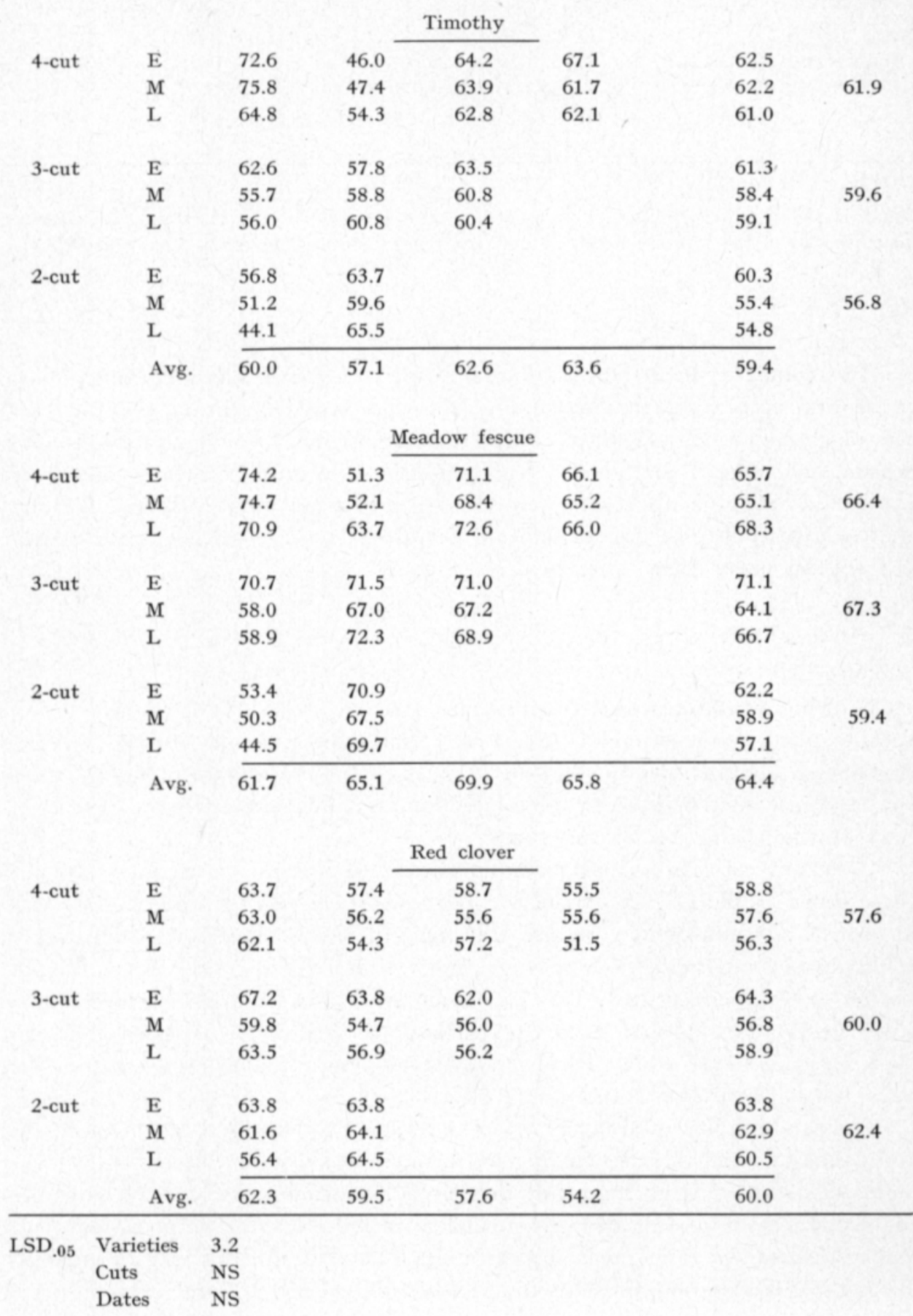



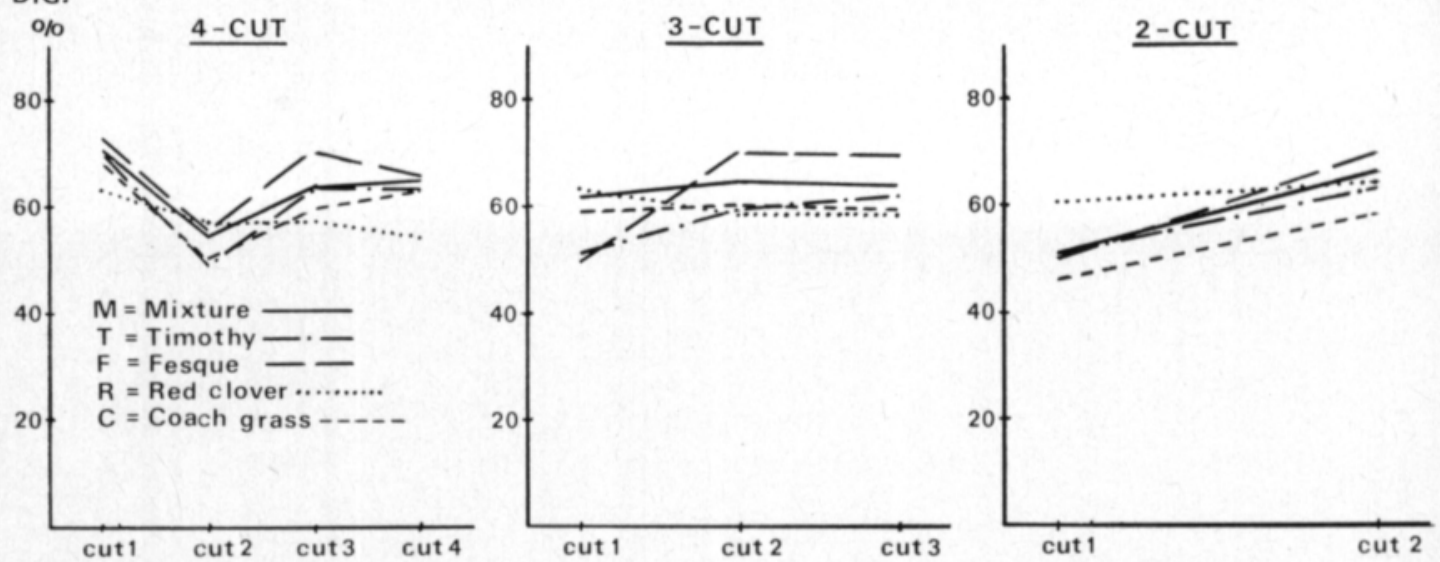

Fig. 14. Cellulase digestibility of dry matter ( $\%$ in DM) of clover-grass stand and different plant species of the mixture in individual cuts harvested two, three and four times in 1974.

The cellulase digestibilities of the different species and the mixture in individual cuts are presented in Fig. 14. The most important point is that the digestibility of red clover is close to unchanging throughout the growing season. The digestibility in different cuts decreased mildly in the 3- and 4-cut systems as autumn approached, but increased in the 2-cut system. The dry matter digestibility of grasses had an increasing trend toward autumn despite the second cut in the 4-cut system (Fig. 14).

\section{4. 3. Discussion}

Growing conditions and the utilization of the stand influence the interspecific plant competition in such a way that it is difficult to make general conclusions about it. On the basis of STÄHLIN's (1959) results it can be concluded that the influence of the environmental factors on the stand is stronger than that of the utilization of the stand.

In this investigation the largest percentage of timothy was in the stand cut three times (Table 22). Nevertheless, meadow fescue was the dominant species in both the 3- and 4-cut systems. The amount of red clover increased evenly when decreasing the cuts from four to two. Red clover was the dominant species in the 2-cut system. This fact thought, differs from RaInINko's (1968) observation and is probably due to the favorable growing conditions and high $\mathrm{N}$-fertilization level which favor grass development under high cutting frequencies as shown by HaKKola (1978).

The productivity of timothy was the least of the three species (Table 22) and equally as high at each cutting frequency. The productivity of red clover increased as the cutting frequency decreased from four to two, and this shows the growth rhythm and competitive ability of red clover. The good regrowth ability of meadow fescue was shown in the 4-cut system, but when compared to timothy it also had a better competitive ability in the 2-cut system. 
Table 22. Average weighted yield characteristics of timothy, meadow fescue, red clover and coach grass and other weeds cut four, three and two times year after seeding in 1974.

\begin{tabular}{|c|c|c|c|c|c|c|c|}
\hline Yield & 7 & Timothy & $\begin{array}{l}\text { Meadow } \\
\text { fescue }\end{array}$ & $\begin{array}{c}\text { Red } \\
\text { clover }\end{array}$ & $\begin{array}{l}\text { Coach } \\
\text { grass }\end{array}$ & $\begin{array}{l}\text { Other } \\
\text { weeds }\end{array}$ & $\begin{array}{l}\text { Inert } \\
\text { matrial }\end{array}$ \\
\hline & & & 4-cut & & & & \\
\hline Species & $\%$ in $\mathrm{DM} ~ . . . . \ldots \ldots \ldots \ldots . . . . .$. & 20.5 & 38.6 & 23.8 & 9.3 & 5.3 & 2.5 \\
\hline , & kg DM/ha .................. & 2535 & 4773 & 2941 & 1148 & 643 & 316 \\
\hline , & prot. $\%$ in DM ............. & 16.7 & 18.7 & 21.6 & 20.8 & & \\
\hline - & cell. dig. $\%$ in DM ........ & 52.7 & 64.6 & 57.2 & 55.6 & & \\
\hline & & & 3-cut & & & & \\
\hline Species & 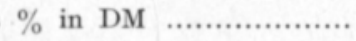 & 23.0 & 32.3 & 28.2 & 8.2 & 5.9 & 2.1 \\
\hline - & kg DM/ha .................. & 2588 & 3628 & 3165 & 929 & 666 & 239 \\
\hline - & prot. $\%$ in DM ............. & 16.6 & 19.3 & 21.4 & 20.1 & & \\
\hline , & cell. dig. $\%$ in DM ........ & 55.0 & 64.4 & 60.2 & 58.6 & & \\
\hline & & & 2-cut & & & & \\
\hline Species & $\%$ in $\mathrm{DM} \quad \ldots \ldots \ldots \ldots \ldots \ldots \ldots$ & 19.2 & 30.5 & 35.1 & 9.9 & 4.1 & 1.2 \\
\hline , & kg DM/ha .................. & 2450 & 3894 & 4479 & 1257 & 519 & 156 \\
\hline , & prot. $\%$ in DM ............ & 14.2 & 16.0 & 17.6 & 16.4 & & \\
\hline , & cell. dig. $\%$ in DM ....... & 54.8 & 59.8 & 61.7 & 49.1 & & \\
\hline
\end{tabular}

The dry matter raw protein contents of red clover, timothy and meadow fescue were nearly the same in the 3 - and 4-cut systems. In the 2 -cut system the protein contents of all species were below the levels of the 3-and 4-cut systems. In all cutting systems the species with the least protein content was timothy and the one with the highest was red clover.

Also, at all cutting frequencies the dry matter cellulase digestibility of timothy was less than for the other species (Table 22). Meadow fescue had the highest digestibility in the 3- and 4-cut systems while red clover had the best in the 2-cut system.

The amount of couch grass was the same in all cutting systems during the first year. The protein content of couch grass was second best after red clover and better than the average for the mixture in all cuts at all cutting frequencies. The dry matter cellulase digestibility of couch grass was the second lowest in the 3- and 4-cut systems and lowest in the 2-cut system.

It can be concluded that, the cutting frequency was the main factor in the productivity of a clover-grass stand, in yield distribution and in grass-legume relationships. Of less importance was the date of the first cut. These results agree with those found by WAGNER (1952).

\section{5. Management post effects}

The productivity of a forage stand in Finland depends to a large degree on the wintering ability of the plants (RAIninko 1968). Of the growth factors during the growing season, early summer drought has proved to limit stand 
Table 23. Post effects of 1974 management technique consisting of three first-cutting dates and three different cutting systems on the DM and protein production and the DM and protein content of 1975 clover-grass stand, cut in all treatments three times in 1975.

\begin{tabular}{lllll}
\hline \multirow{2}{*}{ Cutting time } & \multicolumn{4}{c}{ Cuts } \\
\cline { 2 - 5 } & 4-cut & 3-cut & 2-cut & Avg. \\
\hline
\end{tabular}

DM tons/ha

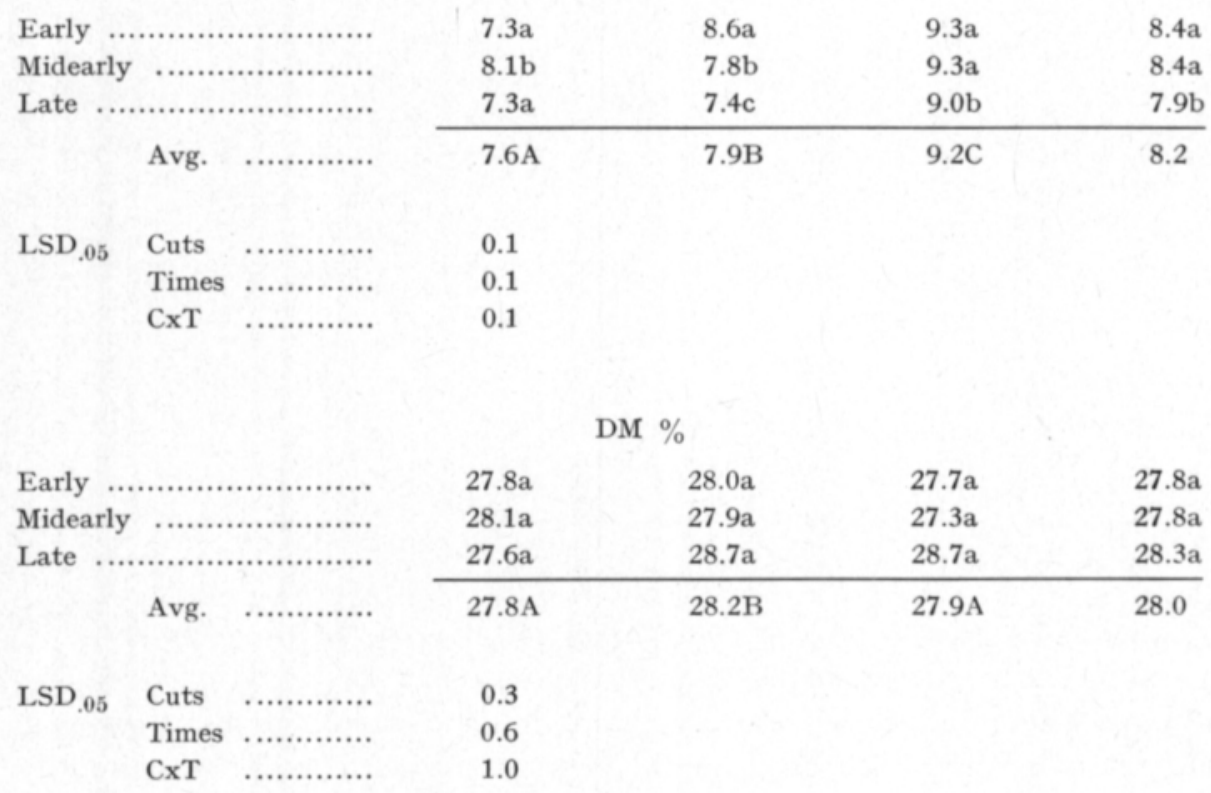

Prot. \%

\begin{tabular}{|c|c|c|c|c|c|c|}
\hline Early & & & $18.4 \mathrm{a}$ & $17.7 \mathrm{a}$ & $18.3 \mathrm{a}$ & $18.1 \mathrm{a}$ \\
\hline Midearly & .......... & 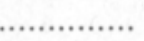 & $18.3 \mathrm{a}$ & $17.8 \mathrm{a}$ & $18.3 \mathrm{a}$ & $18.1 \mathrm{a}$ \\
\hline Late ... & ........... & ........... & $17.7 \mathrm{a}$ & $18.1 \mathrm{a}$ & $18.8 \mathrm{a}$ & $18.2 \mathrm{a}$ \\
\hline & Avg. & .............. & $18.1 \mathrm{~A}$ & $17.9 \mathrm{~A}$ & $18.4 \mathrm{~A}$ & 18.1 \\
\hline $\mathrm{LSD}_{.05}$ & Cuts & ............. & NS & & & \\
\hline & Times & ………... & NS & & & \\
\hline & $\mathrm{CxT}$ & (n............ & NS & & & \\
\hline
\end{tabular}

Prot. kg/ha

\begin{tabular}{|c|c|c|c|c|c|c|}
\hline \multicolumn{3}{|c|}{ 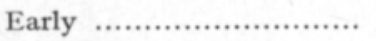 } & $1178 \mathrm{a}$ & $1315 \mathrm{a}$ & $1504 \mathrm{a}$ & $1332 \mathrm{a}$ \\
\hline \multicolumn{3}{|c|}{ 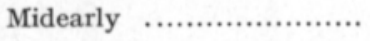 } & $1280 \mathrm{a}$ & $1153 a$ & $1513 a$ & $1315 \mathrm{a}$ \\
\hline \multirow[t]{2}{*}{ Late } & ........... & $\cdots$ & $1126 \mathrm{a}$ & $1172 \mathrm{a}$ & $1545 \mathrm{a}$ & $1280 \mathrm{a}$ \\
\hline & Avg. & n............ & $1195 \mathrm{~A}$ & $1213 \mathrm{~A}$ & $1520 B$ & 1310 \\
\hline \multirow[t]{3}{*}{$\mathrm{LSD}_{.05}$} & Cuts & .............. & 175 & & & \\
\hline & Times & .............. & NS & & & \\
\hline & $\mathrm{CxT}$ & .............. & NS & & & \\
\hline
\end{tabular}


yields the most (Hooli 1971). The annual variation within a forage stand in Finland is great, although less than the variation among most other crops due to the lower temperature requirements of the forage crops (PAATELA and Suomela 1962). According to Pulli (1980) the crop certainty in hay, silage and pasture stands depends on the genetic characteristics, the annual variation in weather conditions and the presence of the local growth factors. Such local growth factors are the characteristics of the growth medium, the stand's establishment, fertilization, age of the stand and the cutting frequency technique.

Results:

The experimental plots of 1974 were divided into halves in $\mathbf{1 9 7 5}$. One half of a plot was treated the same way as in 1974, the other half was cut three times at the same time in all treatments in 1975 in order to test the post effects of the 1974 treatments. In 1976 it was possible to test the two year post effects from those plots treated according to the original management technique throughout both growing seasons.

The post effects of the 1974 cutting dates and cutting frequencies are in Table 23. From these post effects it can be seen that the 1974 treatments only affected the formation of the next year's dry matter yield. Effects on the yield's quality were few and insignificant (Table 23). Also the protein yield of 1975 had no dependence on the 1974 treatments. An increase in the cutting frequency in 1974 meant a lower yield in 1975, as was also observed in the spring of 1975 from the wintering data (Table 24). The best date for the first cut in the 4-cut system was June 7 when the dry matter yield was $1.5 \mathrm{t}$ DM $\mathrm{ha}^{-1}$ and the stand's height was $43 \mathrm{~cm}$ and its regrowth for the second cut was $428 \%$. The earliest first cuts in the 2- and 3-cut systems were the best first cutting dates in regard to the next year's yield.

The effects of two year's treatments as measured in two cuts made in 1976 (Fig. 15) show that the yields of the 4-, 3- and 2-cut systems of 7.3, 7.3 and 7.0 t DM ha-1 did not differ statistically from each other. Also the date of the first cut had no statistical post effects in any of the cutting systems, even if the late cut of the 2-cut system was slightly damaged by dormancy caused by dryness in 1975 . The dry matter content of the 2 -cut system of $23.6 \%$ differed statistically from the 4-cut content of $21.4 \%$ and the 3-cut content of $21.8 \%$.

Table 24. Wintering ability of clover-grass stand evaluated in spring 1975, after one year of management treatments (Scale $10=$ complete wintering. $0=$ complete damage).

\begin{tabular}{|c|c|c|c|c|}
\hline First cutting date & 2-cut & 3-cut & 4-cut & Avg. dates \\
\hline Early ............................. & $9.0 \mathrm{a}$ & $8.7 \mathrm{a}$ & $8.3 \mathrm{~b}$ & $8.7 \mathrm{~b}$ \\
\hline Midearly ......................... & $9.0 \mathrm{a}$ & $8.7 \mathrm{a}$ & $7.3 \mathrm{a}$ & $8.3 \mathrm{a}$ \\
\hline 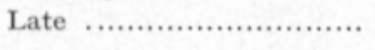 & $9.3 \mathrm{a}$ & $8.0 \mathrm{a}$ & $7.7 \mathrm{a}$ & $8.3 \mathrm{a}$ \\
\hline Avg. & $9.1 \mathrm{~B}$ & $8.5 \mathrm{AB}$ & $7.8 \mathrm{~A}$ & 8.5 \\
\hline
\end{tabular}

$\begin{array}{lll}\text { LSD }_{.05} & \text { Cuts } & 0.9 \\ & \text { Dates } & 0.3\end{array}$



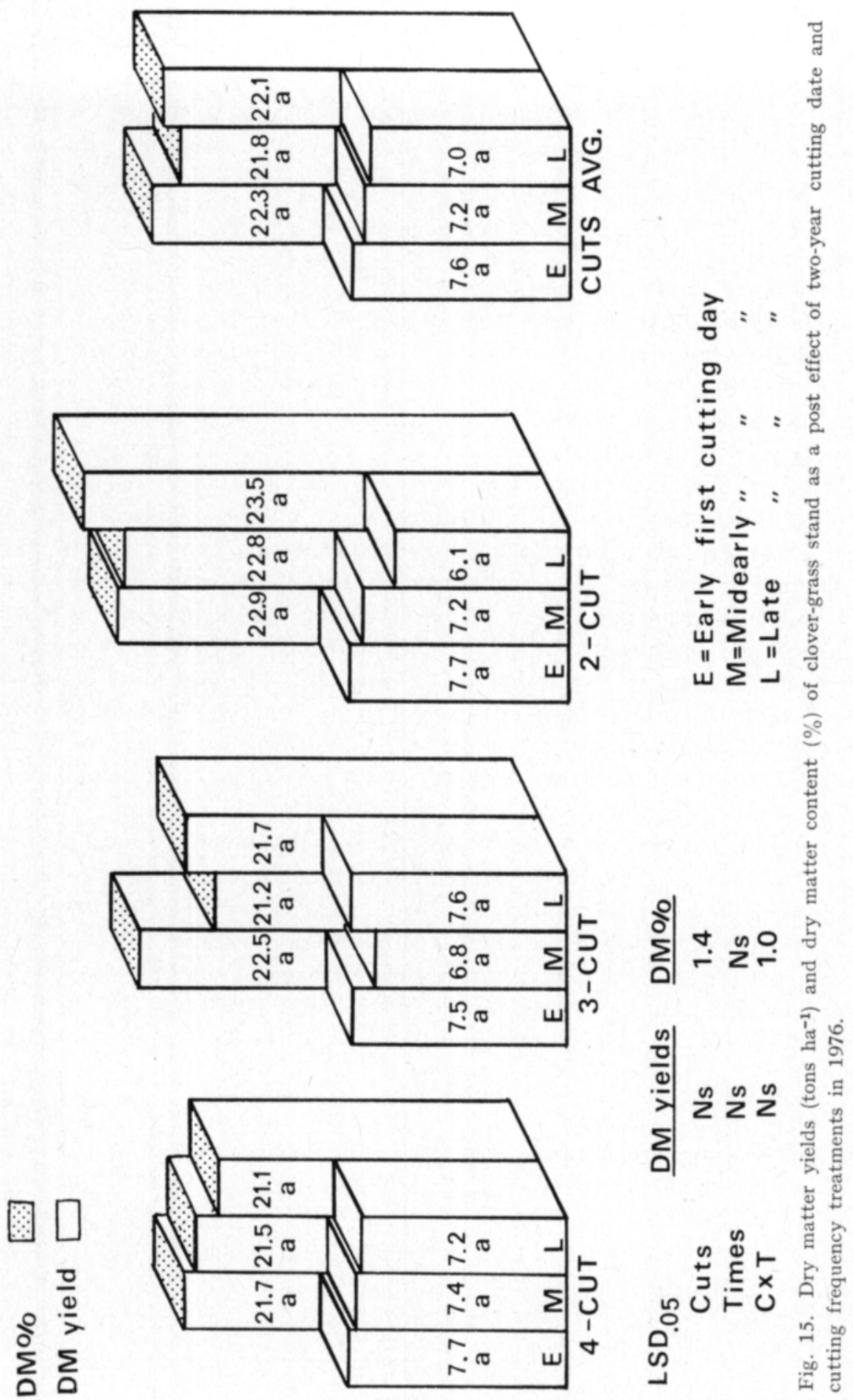
On the basis of the results from the treatment years and post effect evaluation, the cutting frequency and first cutting date are important to the yield distribution during the growing season, the total yield and yield quality formation, and in a mixed stand to the relationships between the plant species. These results support those of VAlle and Virtanen (1932), Poijärvi (1955) Teittinen (1959) and Raininko (1968).

\section{Summary and conclusions}

The effect of the first cutting date and cutting frequency on the clovergrass stand growth and development and the relationships between plant species in the mixture were studied at the University of Helsinki in 1974-76. The second study objective was the relationships between several growth factors and yield components of the stand. The third study area comprised the energy value changes and the photosynthetic activity of the stand during different phases of the growing season.

The following conclusions have been drawn:

Dry matter production:

1. The most important growth factors in the regression model of the dry matter production were temperature sum and solar radiation sum in the spring growth, amount of precipitation during a week before the previous cut and radiation sum in the second cut, amount of precipitation and the physiological state in the third cut and the stand's physiological activity and the amount of autumn precipitation in the fourth cut.

2. The spring growth of a clover-grass stand was the most rapid in the temperature sum range of $400-500^{\circ} \mathrm{C}$. When a growth factor, such as water, was a limiting factor the amount of yield and its quality was difficult to describe as a function of growing time or temperature sum. The best explanation was given by a selective regression model having several growth factors.

3. The regrowth of a stand in the second cut was better the earlier the first cut was made in the 2- and 3-cut systems. In the 4-cut system the best first cutting date for regrowth and for the total yield seems to be at the point where the dry matter content of the stand is the lowest. Otherwise delaying the first cut raised the total yields in the 2- and 3-cut systems.

4. As a result of an early summer drought the stand entered such a deep dormancy that the spring cut was the only significant harvest of the growing season. Under favorable growing conditions equal DM yields were obtained with all cutting frequencies.

5. There was a negative correlation between the first and second cut and positive correlations between the following successive cuts. This indicates that the gain obtained by delaying the first cut is lost in the second cut. High yields in the previous cuts inceases the yields of the third and fourth cuts, indicating the requirement of an active physiological state of the stand. 
6. The stand height growth and DM production of the stand were described mostly in the same way. The variables in the regression model which best described the stand height development were the temperature sum at the first cut, the available water in the second and third cuts and the amount of later summer precipitation and radiation sum in the fourth cut.

\section{Photosynthetic efficiency:}

1. The energy values of the spring and autumn yields were greater than those of the midsummer dry matter yields.

2. The energy value of the DM in the yield decreased somewhat when the first cut was delayed or the cutting frequency increased.

3. Delaying the first cut at any of the cutting frequencies did not change the average assimilation efficiency of the stand.

4. During the favorable growing season in 1974 the cutting frequency did not have any influence on the assimilation efficiency. Under the dry conditions in 1975 the photosynthetic efficiency decreased as the cutting frequency increased. The average assimilative efficiencies were 0.95 and $0.47 \%$ in 1974 and 1975 respectively. The variation range between different treatments was $0.83-1.12 \%$ in 1974 and $0.31-0.68 \%$ in 1975 , presented as a percentage of the total radiation received per surface unit area.

\section{Yield quality characteristics:}

1. The spring temperature sum was the most important variable in explaining a stand's dry matter content, raw protein content, cellulase digestibility in DM and raw protein yield.

- For the second cut the most important variables in each of the regression models for individual quality characteristics were radiation sum for DM content, amount of precipitation for the raw protein content and the amount of precipitation the week before the previous cut for the DM digestibility and formation of the protein yield.

- For the third cut during the driest period of the summer the important variables were the stand's physiological activity for DM content, temperature sum for protein content, amount of precipitation for digestibility and the precipitation the week before the previous cut for the development of the protein yield.

- In the fourth cut the stand's physiological activity as measured by its production ability was the important variable for the dry matter content and development of the protein yield. The radiation sum and temperature sum were the important variables for the raw protein content and digestibility respectively.

2. The dry matter content of the yield decreased in spring until the temperature sum of $420^{\circ} \mathrm{C}$ when the height was $46 \mathrm{~cm}$ and yield about $2.6 \mathrm{t} \mathrm{ha}^{-1}$ After this the dry matter content rose linearly.

3. The DM protein content, digestibility of DM and protein yield in the total yields were mostly influenced by the first cut if made when the slope 
showed either decreasing or increasing values of DM content. Otherwise a late first cutting date or low cutting frequency lowered the quality of the forage.

4. The lowest raw protein content in the primary growth was obtained by mid July. The raw protein content per cut rose accordingly from the first cut of the season to the last and in each cutting system it had a strong negative correlation to the regrowth ability of the stand.

5. The DM digestibility of the primary growth stopped decreasing in mid July. After this it was dependent upon the ratio between the new shoots and matured material of the plant. The differences between digestibilities of cuts made after mid July were very few.

The dependence during regrowth between digestibility and yield level was not nearly as significant as he changes in protein content.

6. During favorable growing conditions the protein yield was influenced by the large dry matter yield and high protein content in the 4-cut system. Under unfavorable conditions and in the 2- and 3-cut systems the protein yield was mainly influenced by the amount of the dry matter yield. The date of the first cut was not important to the formation of the protein yield.

Plant species relationships:

1. The growth of timothy in a clover-grass stand slowed down by the end of June and was replaced by red clover. In the second cut the growth of timothy stopped by mid July and was replaced by meadow fescue. The regrowth of meadow fescue in the third cut was better than that of red clover and timothy. Compared to the regrowth of meadow fescue there was very little late autumn growth of timothy and red clover.

2. In a mixed stand the raw protein content of the plants increased until autumn. Meadow fescue and timothy had the same protein level in all cuts. The protein content of red clover was about $4 \%$-units higher in the spring and autum and about $2 \%$-units higher in the summer than that of grasses.

3. The protein contents of timothy and meadow fescue were almost the same at all cutting frequencies but about $2 \%$-units less than red clover.

4. The cellulase digestibilities of timothy and red clover were, on the average, identical for the whole growing season and about $5 \%$-units less than meadow fescue.

5. The protein contents of red clover and the weed couch grass were higher than that of the mixture, in all cuts of all sutting systems.

\section{Management post effects:}

1. Both the date of cutting and cutting frequency influenced the wintering ability of the stand. In the spring of 1975 the wintering percentage $(78 \%)$ of the 4-cut system was $13 \%$-units less than the stand cut twice in 1974. The difference of $21 \%$-units in dry matter yields favored the 2-cut system. Neither the cutting date nor frequency had any post effect on the quality of the yield.

2. The post effect results of $\mathbf{1 9 7 6}$ show that unfavorable growing conditions balance out the effects of management techniques, but they also reduce the productivity of the stand. 


\section{REFERENCES}

Baeumer, K. 1964. Konkurrenz in Pflanzenständen als Problem der Pflanzenbauforschung. Forschung und Beratung B 10: 99-123.

Bleasdale, J. K. A. 1960. Studies in plant competition. The Biology of Weeds. p. 133-142. Oxford.

Brouwer, W. 1959. Die Feldberegnung. 248 p. Frankfurt am Main.

BRUMMER, V. 1961. Sokerijuurikkaan hehtaaristojen ja säätekijöiden välisestä yhteydestä Suomessa. Summary: On the relations between sugar beet yields and certain climatic factors in Finland. Acta Agr. Fenn. 98: 1-180.

CAPUtA, J. 1948. Untersuchungen über die Entwicklung einiger Gräser und Kleesorten in Reinsaat und Mischung. 127 p. Bern.

Christie, B. R. \& Mowat, D. N. 1968. Variability of in vitro digestibility among clones of bromegrass and orchardgrass. Can. J. Plant Sci. 48:67-73.

Cubillos G., Barnes, R., Noller, C., Cervino, D. \& Ortiz, F. 1970. Effect of age of plant on chemical composition and digestibility in vitro of dry matter of perennial ryegrass, Lolinm perenne. L. Agric. tec. Chile, 30:1-6 (Ref. Nutr. Abstr. 41: 239).

Donald, C. M. 1963. Competition among crop and pasture plants. Adv. Agron. 15: 1-118.

Frank, O. 1952. Kvävegödslingens inflytande på vallskördens storlek och råproteinhalt. Stat. Jordr. förs. Särtr. och Förs. Medd. 60: 1-8.

Fuess, F. \& M. B. Tesar. 1968. Photosynthetic efficiency, yields and leaf loss in alfalfa. Crop Sci. 8: 159-163.

GröвEL, G. \& SteEn, E. 1961. Fröblandningsförsök i betesvall. Stat. Jordbr. fors. Medd. 117: $1-59$.

- 1964. Betens kemiska säsongvariation - resultaten av tre fältförsök. Lantbr.högsk. Medd. A. 21: 1-45.

Guedas, J., Zorita, E., Suarez, A. R. \& Ovejero, F. 1970. Influence of time of cutting on yield of the pastures and nutritive value of the hays. Avances Aliment.mejora animal 11: 387-388, 391-394, 397-400. (Ref. Nutr. Abstr. 41:667).

Guthrie, H. A. 1971. Introductory nutrition. 511 p. 2 nd. Ed. St. Louis.

Hakкola, H. 1978. Nurmikasvikokeiden tuloksia. MTTK. Pohjois-Pohjanmaan koeasema. Tiedote No. 5: 1-28.

HAN, H. J., YANG, J. S., LeE, J. Y. \& PARK, K. J. 1977. Influence of light intensity on the growth and yields of Dystaenia tekesimana and two pasture species. Res. Rep. Off. Rur. Devel. Min. Agric. Fish. 19: 123-128.

Hari, P. \& Leikola, M. 1974. Further development of the dynamic growth model of plant height growth. Flora Bl. 163:357-370.

Heınonen, R. 1968. Tidig vårsådd. Växtfysiologiska och ekologiska synpukter på aktuella tendenser i såbädds beredning och sådd av vårstråsäd. Lantbr.högsk. Rapp. Jordbearb. abd. 13: 1-19.

Holliday, R. 1966. Solar energy consumption in relation to crop yield. Agric. Progr. 41: 2434.

Holmes, W. \& Mac Lusky, D. S. 1955. The intensive production of herbage for crop drying. 6. A standy of the effect of intensive nitrogen fertilizer treatment on species and strains of grass, grown alone and with white clover. J. Agric. Sci. 46: 267-286.

Номв, Т. 1953. Chemical composition and digestibility of grassland crops. Acta Agric. Scand. 3: $1-32$.

Hoolı, J. 1971. Säätekijöiden vaikutuksesta viljelykasvien satoihin. Helsingin teknillinen korkeakoulu. Tiet. julk. 35: 1-243.

HUoKuna, E. 1960. Grazing on herbage at different grazing stages, its effect on a cocksfoot dominant ley and on milk production. Valt. Maatal. koetoim. Julk. 177: 1-44.

- 1964. The effect of frequency and height cutting on cocksfoot swards. Ann. Agric. Fenn. 3: 1-83.

- 1973. Valkuaisen tuotanto nurmilla. 1. Viljelytutkimukset. Koetoim. ja Käyt. 30: 12.

- , Jatila, T. \& RuUttunen, E. 1962. Koiranheinän korrenmuodostuksesta laidunnurmessa ja sen ehkäisemisestä. Suomen Laiduntalous 34: 43-50. 
JoHansson, O. V. 1912. Uber Wasserstands- und Klimaschwankungen in Nordeuropa nach Wallen u.a. Meteorol. Zschr. 29: 261-262.

- 1924. Vereinfachungen der Korrelationsberechnungen nebst einigen Anwendungen. Meteorol. Zschr. 41: 358-361.

Joнansson, W. 1965. Bevattning anpassning till mark, gröda och väderleksförhållanden. Akt. Lantbr. högsk. 74: 18-21.

Jones, M. 1936. Competition between species under pasture conditions. Agric. Progress 12: $2-65$.

Jones, D. I. H. \& HAYward, M. W. 1973. A cellulase digestion technique for predicting the dry matter digestibility of grasses. J. Sci. Fd. Agric. 24: 1419-1426.

JÄNтTI, A. 1953. Koiranheinä ja nurminata lyhytikäisten laidun- ja säilörehunurmien valtakasveina. Acta Agr. Fenn. 81:1-64.

- \& Heinonen, R. 1957. Effect of defoliation and soil moisture on grassland re-growth. J. Brit. Grassl. Soc. 12, 1: 56-61.

JäĀSKelärnen, O. 1929. Viljelyslaidun 360 p. Porvoo.

Kallinen, A., Рohjonen, V. \& PĀĀKYLÄ, T. 1976. Viljelyvarmuudesta. MTTK, Kasvinviljelylaitoksen tiedote No. 1:1-37.

KameL, M. S. 1959. A physiological study of shading and density effects on the growth and efficiency of solar energy conversation in some field crops. Medel. Landbouwhogesch. Wageningen 59: 1-101.

KELLY, A. F. 1958. A comparison between two methods of measuring seasonal growth of two strains of Dactylis glomerata when grown as spaced plants and swards. J .Brit.Grassl. Soc. 13: $99-105$.

KERÃNEN, J. 1925. On the dependence of the harvest upon the temperature in the foregoing winter and May. Valt. Mereorol. Keskusl. Toim. 15: 1-8.

- 1931. Vuodentulon riippuvaisuudesta kasvukauden lämpö- ja sadeoloista Suomen en lääneissä. I. Korrelaatiotekijät. Referat: Ủber die Abhängigkeit der Ernteerträge von den Temperaturen und Regenmengen während der Vegetationszeit in Finnland. I. Korrelationsfaktoren. Acta Agr. Fenn. 23, 1:1-32.

KIISKINEN, A. 1957. Sadon riippuvuus väkilannoituksen ja lämpöolojen vaihteluista Suomessa. Summary: The dependency of the yield on changes of the volume of fertilization and summer temperature in Finland. Maatal.tiet. Aikak. 29: 211-217.

KIVIMÄE, A. 1959. Chemical composition and digestibility of some grassland crops. Acta Agric. Scand. Suppl. 5:1-142.

- 1965. Timotejhöets sammansättning och smältbarhet vid framstridande skördestadier. Lantbr.högsk. Medd. A. 37: 1-23.

KLAPP, E. 1937. Uber einige Wachstumrregeln mehrjährigen Pflanzen unter der Nachwirkung verschiedener Nutzungsweise. Pflanzenbau 14: 209-224.

- 1951. Leistung, Bewurzelung und Nachwuchs einer Grassnarbe unter verschiedener häufiger Mähe und Beweidung. Z. Acker- und Pfl.bau 93: 269-286.

KoRHONEN, V. 1918. Kevättulvasta ja kesäkauden sateista maanviljelysoloja silmälläpitäen. Maatal.hall. Tied. 123: 1-36

- 1920. Pouta kasvukautena Suomessa. Vipusten juhlajulkaisu G. Melanderin 60-vuotispäiväksi. p. 96-117. Porvoo.

- 1940. Kasvukauden sademäärä Suomessa. Maat.tiet. Aikak. 4:157-178.

Kramer, P. 1959. Transpiration and the water economy of plants. Plant Physiol. 2: 607 -709 .

KöYLIJ ĀRVI, J. 1960. Kvävegödslingens inverkan på mängden och kvaliteten av kväveföreningar samt mineralsammansättningen hos betegräs. Nord. Jordbr.forskn. 42. Suppl. 2: $132-135$.

Leafe, E. L., Stiles, W. \& Dickinson, S. E. 1974. Physiological processes influencing the pattern of productivity of the intensively managed grass swards. Proc. $12^{\text {th }}$ Int. Grassl. Congr. Moscow. Biological and physiological aspects of the intensification of grassland utilization. p. $191-205$.

Lehtisalo, P. 1956. Puna-apilasta laidunnurmissamme. Laidunyhd. Julk. 31:23-36.

LEMSTRöM, S. 1878. Om periodiska förändringar i några meteorologiska fenomen, deras samband med förändringar $\mathrm{i}$ solen och sannolika inflytande på årsväxten. Finsk Tidskr. 1878. Tom IV. p. $407-423$. 
LiNJA-Aно, M. 1952. Nurmikasvilajimme kuivien kesien kokemusten valossa. Karjatalous 28: $560-563$.

Lınкolı, O. 1948. Nurmiviljelystarkkailu ja sen kehittäminen. Maatal. ja Koetoim. 3: 31 -43.

Loomis, R. \& W. Williams. 1963. Maximum crop productivity: an estimate. Crop Sci. 3: $67-72$.

Marttila, M. \& RaAtikainen, T. 1967. Niittonurmien sato vuonna 1967. Koetoim. ja Käyt. 24: $37,39$.

Maximov, N. 1938. Plant physiology. 473 p. (Ed. R. Harvey and Murneek). Mc Gaw-Hill Brok Co. New York.

Mela, T. 1974. Growth and herbage quality of meadow fescue (Festuca pratensis Huds.) under different wather conditions. Ann. Agric. Fenn. 13: 119-124.

- \& M. HaApalainen. 1976. Hehtaarisatojen ja tärkeimpien satoon vaikuttavien tekijöiden kehitys vuosina 1956-75 ja ennuste vuoteen 1985. MTTK, Kasvinviljelylaitoksen tiedote $4: 1-60$.

Minson, D., Harris, C. E., Raymond, W. F. \& Mrlford, R. 1964. The digestibility and voluntary intake of S22 and $\mathrm{Hl}$ ryegrass, S 170 tall fescue, S 48 timothy, S 215 meadow fescue and Germinal cocksfoot. J. Brit. Grassl. Soc. 19: 298-305.

- , Raymond, W. F. \& Harris, C. E. 1960. The digestibility of grass species and varieties. Proc. $8^{\text {th }}$ Int. Grassl. Congr. Reading. p. 470-474.

Mitchell, K. J. 1956. Growth of pasture species under controlled environment. 1. Growth at various levels of constant temperature. N. Z. J. Sci. Technol. 38: 203-216.

Mowat, D. N., Christie, B. R. \& Winch, J. E. 1965. The in vitro digestibility of plant parts of orchardgrass clones with advancing stages of maturity. Can. J. Plant Sci. 45: 503-507.

Mukula, J. \& O. Rantanen. 1976. Syysvehnän viljely Suomessa 1950-1975. MTTK, Kasvinviljelylaitoksen tiedote 3: 1-35.

- 1978. Kevätviljojen siementuotannon alueelliset edellytykset. MTTK, Kasvinviljelylaitoksen tiedote 12: 1-29.

- , Rantanen, O. \& Lallukka, U. 1977. Ohran viljelyvarmuus Suomessa 1950-1976. MTTK, Kasvinviljelylaitoksen tiedote 9: 1-83.

- 1978. Kauran viljelyvarmuus Suomessa 1950-1976. MTTK, Kasvinviljelylaitoksen tiedote 10:1-64.

- , RaAtikainen, T. \& Martilla, M. 1967. Heinäsatojemme kasvilajikoostumus v. 1966. Koetom. ja Käyt. 24: 6 .

- , Rantanen, O., Lallukka, U. \& Pohjonen, V. 1976. Rukiin viljelyvarmuus Suomessa 1950-1975. MTTK, Kasvinviljelylaitoksen tiedote 5:1-77.

Мицтамйкі, K. 1961. Der Einfluss klimatischer Faktoren auf die Entwicklung von Erbse. Maatal.tiet. Aikak. 33: 256-266.

Noddack, W. \& КомоR, J. 1937. Über die Ausnutzung des Sonnenlichtes beim Wachstum der grünen Pflanzen unter natürlichen Bedingungen. Angewandte Chem. 50: 271-277.

Older, H. \& LinnutaJA, A. 1976. Heintaimedesaaki ja seeduvuse söltuvus koristusaegsest arengufaasist. Sotsialistlik Pollumajandus 9: 398-403.

OLofsson, S. 1962. Tillväxt och kemisk sammansättning hos några vallgräs under våren och försommaren. Stat. Jordbr.förs. Medd. 135: $123 \mathrm{~s}$.

PaAtel. J. 1953. Maamme heinänurmien botaanisesta koostumuksesta. Acta Agr. Fenn. 79: $1-128$.

- 1958. Varför stiger inte hektarskördarna? Nord. Jordbr. forskn. 40: 95-104.

- \& Suomela, H. 1960. Kevätviljojen viljelyvarmuudesta. Summary: On the certainty obtaining a crop of spring cereals in Finland. Maatal. ja Koetoim. 14: 51-62.

- 1962. Peltokasvien sadoista niiden määrään vaikuttavista tekijöistä sekä odotettavissa olevasta kehityksestä. 39 p. Helsinki.

Pessı, Y. 1958 a. Hallojen esiintymisestä ja niiden aiheuttamista vahingoista Suomessa. Summary: On the occurence of night frost in Finland. Acta Agr. Fenn. 93, 3: 1-43.

- $1958 \mathrm{~b}$. On the influence of bog draining upon thermal conditions in the soil and in the air near the ground. Acta Agric. Scand. 8: 359-374.

Pestalozzı, M. \& Øyen, J. 1977. Forsøk med sortar av fleiråring raigras 1970-76. Forskn.fors. Landbr. 28: 661-673. 
Phillipson, J. 1964. A miniature bomb calorimeter for small biological samples. Oikos 15: 1 Copenhagen.

Ронјакаllıo, O. 1943. Uber die Abhängigkeit der Resistenz gegen die Trockenperiode und Reifesicherheit von Entwicklungsrhytmus bei Hafer. Gerste und Sommerweizen. Maatal.tiet. Aikak. 15: 105-125.

- 1948. Nurmikasvilajien, -kantojen ja jalosteiden viljelysarvo Suomessa suoritettujen tutkimusten valossa. Suomen Laiduntalous 21: 5-38.

- 1951 a. On the effect of the intensity of light and length of day on the energy economy of certain cultivated plants. Acta Agric. Scand. 1: 153-175.

- 1951 b. Uber den Einfluss der Umweltfaktoren auf die Dauer der Zeit von der Aussaat bis zum Ähren-(Rispen)-Schieben bei Sommergetreide. Soc. Scient. Fenn. Comm. Biol. 11, 6: 1-18.

- 1952. Ljusintensiteten i norra och södra Finland samt dess inverkan på odlingsväxterna. Nord. Jordbr.forskn. 34: 99-112.

- 1954. On the effect of light conditions on the dry matter yield, dry matter content, and root-top ratio of certain cultivated plants. Acta Agric. Scand. 4: 289-301.

- 1957. Light, climate and crop growth in Finland. Field crop abstr. 10: 77-82.

Ронјакallio, O. \& Antila, S. 1955. On the effect of removal of shoots on the drought resistance of red clover and timothy. Acta Agric. Scand. 5: 239-244.

- \& Salonen, A. 1947. Der Einfluss der Tageslänge auf Entwicklung und Energiehaushalt einiger Kulturpflanzen. Acta Agr. Fenn. 67: 1-51.

Ронјалнегмо, O. 1959. Lämpö- ja sadeolojen vaikutuksesta kevätviljoihin Jokioisissa 19301954. Referat: Einfluss der Temperatur und der Niederschlagshōhe auf die Entwicklung der Sommergetreide in Jokioinen in den Jahren 1930-54. Maatal. ja Koetoim. 13: $87-97$.

PoIJÃRvi, I. 1931. Korjuuajan vaikutus heinäsadon määrään ja laatuun Valt. Maatal.koetoim. Julk. 35: 1-93.

- 1955. Korjuuajan, -tavan ja -sään vaikutus nurmesta saadun rehusadon määräån ja ravintoarvoon. Maatal. ja Koetoim. 9: 197-205.

Poutıainen, E. \& Rinne, K. 1971. Korjuuasteen vaikutus säilörehun ravintoarvoon. Kehittyvä Maatalous 3: 15-28.

- 1976. Typpilannoituksen vaikutus säilörehun ravintoarvoon. Kehittyvä Maatalous 29: 14-21.

Pritchard, G., Folkins, L. \& Pigden, W. 1963. The in vitro digestibility of whole grasses and their parts at progressive stages of maturity. Can. J. Plant Sci. 43: 79-87.

Pulli, S. 1976. Cellulase digestion technique compared with the in vitro digestibility of forages. J. Scient. Agric. Soc. Finl. 48: 187-194.

- 1980. Nurmien viljelyvarmuus. Maataloustutkimuksen päivät 4.-5.3.1980. Esitelmämoniste I: $1-6$.

Rabinowitch, E. 1945. Photosynthesis and Related processes. 599 p. Vol. 1 Intersience pub. Inc. New York.

RaIninko, K. 1968. The effects of nitrogen fertilization, irrigation and number of harvestings upon leys established with various seed mixtures. Suom. Maatal.tiet. Seur. Julk. 112: $1-136$.

- 1973. Onko kasvinjalostuksella mahdollisuuksia parantaa nurmikasvien laatua? Karjatalous 5: 8-9.

RAPPE, G. 1948. Några för betestillväxten karakteristiska grunddrag. Sv. Vall- och mosskulturför. Medd. 14: 585-788.

Ravantri, S. 1955. Nurmikasvilajiemme satoisuussuhteista. Summary: On the relative yields of different grassland plants. Maatal. ja Koetoim. 9: 112-118.

Raymond, W. F. 1969. The nutritive value of forage crops. Adv. Agron. 21: 1-108.

Reid, J. T., Kennedy, W. K., Turk, K. L., Slack, S. T., Trimberger, G. W. \& Murphy, R. P. 1959. Effect of growth stage, chemical composition and physical properties upon the nutritive value of forages. J. Dairy Sci. 42: 567-571.

ReYnolds, J. H., BARTH, K. M. \& FRYeR, M. E. 1969. Effect of harvest frequency and nitrogen fertilization on estimated total digestible nutrients of orchardgrass (Dactylis glomerata L.) regrowth. Agron. J. 61: 433-435. 
SALminen, M. 1930. Kasvuajan, sademäärän ja keskilämpötilan vaikutus lämpöasteiden summaan ja kasvuajan pituuteen Tammistossa 1925-29. Hankkijan kasvinjalostuslaitos. Siemenjulkaisu 1930: 87-92. Helsinki.

SALO, M-L. 1976. Olisiko syytä määrittää säilörehun rehuarvo jo valmistusvaiheessa. Karjatalous 52: $27-30$.

- , Nykänen, A. \& Sormunen, R. 1975. Nurmikasvien koostumus, pepsiini-HC1liukoisuus ja in vitro -sulavuus eri kasvuasteilla. J. Scient. Agric. Soc. Finl. 47: 480490.

SAlohermo, L. 1956. Sademäärien vaikutus kauran satoisuuteen. Koetoim. ja Käyt. 13: 21.

SAlonen, M. 1959. Puna-apilan suhtautumisesta typpilannoitukseen. Maatal. ja Koetoim. 12: $204-207$.

SAlONen, M. \& Hrvola, S-L. 1963. Typpilannoituksen vaikutus puna-apilan ja nurminadan sadon määräån ja laatuun. Ann. Agric. Fenn. 2: 136-152.

SAU, A. \& Virralt, R. 1974. Increase of yield and improvement in quality of grassland herbage at grazing and frequent cutting in the Estonian SSR. Proc. 12 ${ }^{\text {th }}$ Int. Grassl. Congr. Moscow. Utilization 2: 606-611.

SEPPÃNEN, E. 1971. Influence of weather condition and late blight on the yields of potatoes in Finland, 1931-62. Ann. Agric. Fenn. 10: 65-109.

Sinisalo, J. 1937. Die für das Reifen gewisster Sommerweizen- und Gerstensorten erforderlichen Wärmesummen und Anzahlen von Wachstumstagen. Maatal.tiet. Aikak. 9: 194-212.

SoINI, S. 1965. Paikallisten lannoituskokeiden heinäsatoihin vaikuttavista tekijöistä. Summary: A statistical study of factors affecting the yields of leys in local experiment fields. Ann. Agric. Fenn. 4:185-206.

STEEN, E. 1972. Stigande mängder kväve till fem vallgräsarter skördade tre gånger per säsong. Lantbr.högsk. Medd. A. 176: 1-43.

Stıgell, R. V. 1920. Kesäkuun keskilämpötilojen vaikutuksesta Suomen kokonaissatoihin vuonna 1886-1905. Vipusen juhlajulkaisu G. Melanderin 60-vuotispäiväksi. p. 153156. Porvoo.

Sullivan, J. T., Phillips, T. G., Loughlin, M. E. \& Sprague, V. G. 1956. Chemical composition of some forage grasses. 2. Successive cuttings during the growing season. Agron. J. 48: 11-14.

SYRJÄLÄ, L. 1973. Mennyt kesä ja vihreä linja. Karjatalous 49: 42-43.

- 1974. Säiliörehun raaka-aineen korjuuaste. Kehittyvä Maatalous 20: 27-37.

Tertrinen, P. 1958. Nurminadan ja koiranheinån satoisuudesta puna-apilaan verrattuna. Maatal. ja Koetoim. 12: 277-280.

- 1959. Apilanurmen niittoaikakokeitten tuloksia. Maatal. ja Koeteim. 13:208-217.

Tilley, J., Terry, R., Deriaz, R. \& Outen, G. 1960-64. Studies of herbage digestibility using in vitro method. Exp. in progress. The G. R. I. 14: 56-58, 16: 64-67, 17: $63-64$.

TÄHTINEN, H. 1962. Säätekijät ja perunasato. Lisensiaattityö, Helsingin yliopisto 105 p. Helsinki.

UTAAKER, K. 1968. A temperature growth index the respiration equivalent used in climatic studies on the mesoscale in Norway. Agr. Meteorol. 5: 351-359.

VAlle, O. \& Virtanen, A. I. 1932. Tutkimuksia niittoajan vaikutuksesta heinäsadon suuruuteen ja laatuun. Valion Laborat. Julk. 1932: 1-24.

VALmari, A. 1968. Missä peltoalaa on supistettava, Etelä- vaiko Pohjois-Suomessa. Kaleva 69, 291: 8 .

VARIS, E. 1970. Variation in the quality of table potato and the factors influencing it in Finland. Acta Agr. Fenn. 118, 3: 1-99.

- , Hutrunen, R. \& Zitring, M. 1979. Rehuohran laatu Suomessa vuosina 19671974. Helsingin yliopisto, Kasvinviljelytieteen laitos, Julkaisuja 7: 1-94.

- , Pirilã, O., Huttunen, R., Tupakka, K. \& Lallukka, U. 1979. Kauran laadun vaihteluista Suomessa. Helsingin yliopisto, Kasvinviljelytieteen laitos, Julkaisuja 4: $1-85$.

WAGNER, R. E. 1952. Yields and botanical composition of four grass-legume-mixtures under different cutting. U.S. Dept. Agric. Techen. Bull. 1063: 1-53. 
Walters, R., Griffith, G., Hughes, R. \& Jones, D. 1967. Some factors causing differences in digestibility of grasses measured by an in vitro method. J. Brit. Grassl. Soc. 22, 2: $112-116$.

WARREN Wilson, J. 1960. Influence of spatial arrangement of foliage area on light interception and pasture growth. Proc. $8^{\text {th }}$ Int. Grassl. Congr. Reading. p. 275-279.

WASsINK, E. 1948. Light as a factor in photosynthesis and its relation to other environmental factors. Meded. Dir Tuinbouw 11: 503-513.

Winkler, H., Ohlsson, S. \& Hellberg, A. 1961. Skördetidförsök i vall kombinerande med konsevering och smältbarhetsförsök. Stat. Jordbr.förs. Medd. 118: 1-25.

Åberg, E., Johanson, I. J. \& Wilsie, C. P. 1943. Associations between species of grasses and legumes. J. Am Soc. Agron. 35: 357-369.

YLLö, L. 1963. Einfluss von Temperatur und Niederschlag auf Knollenertrag und Stärkegehalt bei Kartoffeln. Ann. Agric. Fenn. 2: 59-72.

- 1964. Einfluss von Temperatur und Niederschag auf den Kartoffelertrag von Sortenversuchen in Finland. Ann. Agric. Fenn. 3: 256-264.

Ms received April 12, 1980.

SELOSTUS

\title{
Viljelytoimenpiteiden ja kasvutekijöiden vaikutus apila-heinänurmen kasvurytmiin ja sadonmuodostukseen
}

\author{
SEPPO PULLI \\ Helsingin yliopisto, Kasvinviljelytieteen laitos, 00710 Helsinki 71
}

Helsingin yliopiston koetilalla Viikissä tutkittiin 1974-76 ensimmäisen niiton ajankohdan ja niittokertojen lukumäärän vaikutusta apila-heinänurmen kasvuun ja kehitykseen sekä kasvilajien välisiin määrällisiin ja laadullisiin suhteisiin. Toisena tutkimuskohteena olivat kasvutekijäin ja satokomponenttien väliset suhteet eri kasvuvaiheissa. Kolmantena selvityksen kohteena olivat seosnurmen kuiva-aineen energia-arvon mutokset ja fotosynteettinen tehokkuus kasvukauden eri ajankohtina.

Sekanurmen kasvu oli tehokkainta lämpötilasumma-alueella $400-500^{\circ} \mathrm{C}\left(\Sigma>0^{\circ} \mathrm{C}\right)$. Tärkeimmät kuiva-ainesadon muodostumista kuvaavat muuttujat regressiomallissa olivat lämpötilasumma ensimmäisessä niitossa, viikon aikana ennen edellistä niittoa saatu sade toisessa niitossa, niittojen välinen sadesumma kolmannessa niitossa ja edellisen niiton kasvuston kasvupotentiaali neljännessä niitossa. Ensimmäisen ja toisen niiton satojen välillä vallitsi negatiivinen korrelaatio. Erilaiset korrelaatiot olivat indikaattoreita siitä, että ensimmäisen niiton ajankohtaa myöhästyttämällä saatu sadonlisä johtaa sadon alenemiseen toisessa niitossa, mutta korkea satotaso loppukesän niitoissa edellyttää aktiivista sadonmuodostumista aina edellisessä niitossa. Kokonaissadoissa ensimmäisen niiton ajankohdan myöhästyttäminen lisăsi eniten satoa 2- ja 3-niittosysteemeissä ja vähiten 4-niittosysteemissä, jossa kaksi keskimmäistä niittoa saattaa sattua kasvukauden kuivalle jaksolle.

Alkukesällä kuukauden sateeton ajanjakso aiheutti kasvustolle niin syvän dormanssin, että oli mahdollista saada vain yksi sato.

Kevään ja syksyn kuiva-ainesadon energia-arvo oli suurempi kuin keskikesällä. Keskimääräinen yhteyttämistehokkuus oli v. $19740.95 \%$ ja v. $19750.47 \%$ laskettuna pinta-alalle tulleesta kokonaissäteilystä ja $2.26 \%$ ja $1.11 \%$ näkyvän valon alueella. Suotuisana kasvukautena niittotiheydellä ei ollut vaikutusta yhteyttämistehokkuuteen.

Kasvuston ka-pitoisuus aleni kevätkasvussa lämpötilasumman $420^{\circ} \mathrm{C}$ saakka ja kasvoi tämän jälkeen lineaarisesti. 4-niittosysteemin kokonaissadoissa kuiva-ainepitosuuden, raakavalkuaispitoisuuden ja valkuaissadon muodostumiseen sekä kuiva-aineen sulavuuteen vaikutti voimakkaimmin se, tehtiinkö ensimmäinen niitto kevään kuiva-ainepitoisuuden ollessa vielă 
laskeva tai sen ollessa nouseva. Muutoin niiton myöhästyttäminen tai niittokertojen vähentäminen huononsi rehun laatua.

Sekanurmessa timotein kevätkasvu pysähtyi kesäkuun loppuun mennessä, jolloin sen syrjäytti puna-apila. Toisessa niitossa timotein kasvu pysähtyi heinäkuun puoliväliin mennessä, jolloin sen syrjäytti nurminata. Tuottavuus syksyä kohden aleni ensin timoteilla, sitten punaapilalla ja viimeksi nurminadalla. Proteiinipitoisuudet eri niittotiheyksillä olivat sekaruohossa timoteilla ja nurminadalla hyvin lähellä toisiaan ja n. $2 \%$-yksikköä alemmat kuin punaapilalla. Timotein ja puna-apilan kuiva-aineen sellulaasisulavuudet olivat koko kasvukauden lähes yhteneväiset ja n. $5 \%$-yksikköä alemmat kuin nurminadalla.

Yhden kasvukauden jälkivaikutuksena merkitsi 4-niittosysteemin $13 \%$-yksikköä 2-niittoa heikompi talvehtiminen (visuaalisena havaintona) $21 \%$-yksikköä alhaisempaa satotasoa. Vuoden 1975 vedenpuute osoitti, että epäedulliset kasvuolot tasaavat viljelyteknillisiä jälkivaikutuksia, mutta samalla alentavat kasvuston yleistä kasvukuntoa. 